\title{
ANALYSIS OF ENVIRONMENTAL FACTORS IMPACTING THE LIFE-CYCLE COST ANALYSIS OF CONVENTIONAL AND FUEL CELL/BATTERY-POWERED PASSENGER VEHICLES
}

\section{FINAL REPORT}

\author{
Prepared for: \\ U.S. Department of Energy \\ Chicago Field Office \\ Contract No. DE-AC02-93CE50212
}

Prepared by:

Engineering Systems Management, Inc.

501 Manor Brook Drive

Silver Spring, Maryland 20905

(301) 879-0743; Fax (301) 879-0744

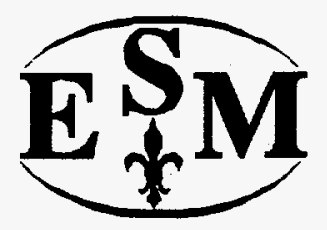

January 31, 1995

DISTRIBUTION OF THIS DOCUMENT IS UNLIMTTED 


\section{DISCLAIMER}

Portions of this document may be illegible in electronic image products. Images are produced from the best available original document. 


\section{DISCLAIMER}

This report was prepared as an account of work sponsored by an agency of the United States Government. Neither the United States Government nor any agency thereof, nor any of their employees, makes any warranty, express or implied, or assumes any legal liability or responsibility for the accuracy, completeness, or usefulness of any information, apparatus, product, or process disclosed, or represents that its use would not infringe privately owned rights. Reference herein to any specific commercial product, process, or service by trade name, trademark, manufacturer, or otherwise does not necessarily constitute or imply its endorsement, recommendation, or favoring by the United States Government or any agency thereof. The views and opinions of authors expressed herein do not necessarily state or reflect those of the United States Government or any agency thereof. 


\section{Table of Contents}

Page

EXECUTTVE SUMMARY $\ldots \ldots \ldots \ldots \ldots \ldots \ldots \ldots \ldots \ldots \ldots \ldots \ldots \ldots$

1.0 INTRODUCTION $\ldots \ldots \ldots \ldots \ldots \ldots \ldots \ldots \ldots \ldots \ldots \ldots \ldots \ldots$

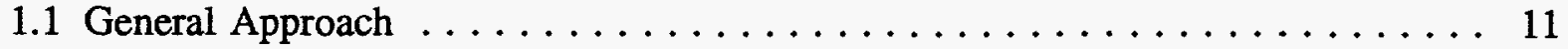

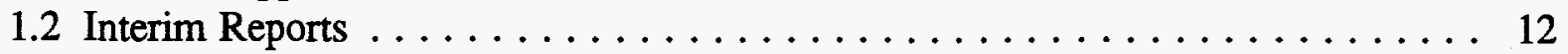

2.0 EXPANDED ENVIRONMENTAL ANALYSIS OF THE ALTERNATIVE TRANSPORT SYSTEM LIFE CYCLE COST MODEL . . . . . . . . . . 13

2.1 Methodology of Selection of Additional Emission Cases $\ldots \ldots \ldots \ldots \ldots 13$

2.1.1 Greenhouse Gases . . . . . . . . . . . . . . . . . . 14

2.1.2 Nitrogen Oxides, Carbon Monoxide, and Sulfur Oxides .......... 15

2.1.3 Particulate Matter ......................... 16

2.1.4 Toxics (Including Hydrocarbons) $\ldots \ldots \ldots \ldots \ldots \ldots \ldots \ldots \ldots \ldots$

2.2 Cost Basis for Externalities, Associated Unit Costs for Emission Avoidance,

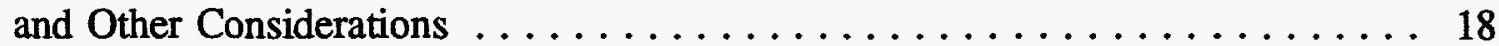

2.2.1 Cost Basis for Externalities and Associated Unit Costs . . . . . . . . 18

2.2.1.1 Greenhouse Gases ................... 20

2.2.1.2 Nitrogen Oxides, Carbon Monoxide, and Sulfur Oxides ...... 20

2.2.1.3 Particulate Matter . . . . . . . . . . . . . . . 21

2.2.1.4 Toxics (Including Hydrocarbons) $\ldots \ldots \ldots \ldots \ldots \ldots \ldots 21$

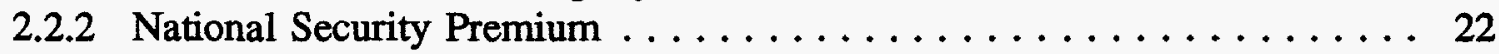

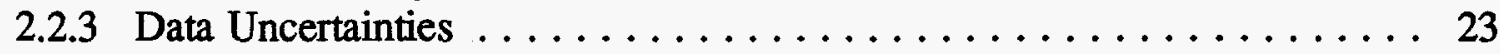

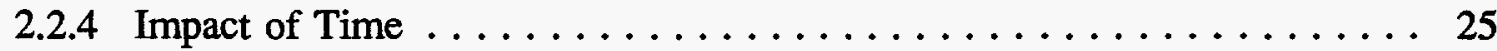

3.0 CHARACTERISTICS OF THE LIFE CYCLE COST MODEL FOR HYDROGEN PROTON EXCHANGE MEMBRANE FUEL CELL/BATTERY-POWERED VEHICLES AND LCC ANALYSIS $\ldots \ldots \ldots \ldots \ldots \ldots \ldots \ldots \ldots \ldots \ldots \ldots \ldots \ldots \ldots \ldots$

3.1 Characteristics of the LCC Model for Hydrogen PEMFC/Battery Vehicles . . . . 27

3.1.1 Hydrogen PEMFC Characteristics ................. 27

3.1.2 Onboard Hydrogen Storage Characteristics . . . . . . . . . . 28

3.1.3 Environmental Emissions Characteristics . . . . . . . . . . . . 29

3.1 .4 Hydrogen Fuel Characteristics . . . . . . . . . . . . . . . . . 29

3.1.5 Maintenance and Repair Characteristics ............... 30

3.2 Life Cycle Cost Analysis . . . . . . . . . . . . . . . . . 31

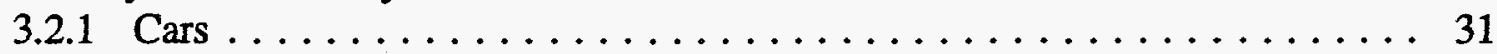

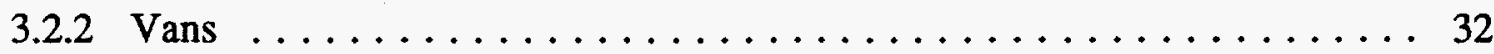


Table of Contents (Continued)

Page

4.0 NEW OPERATIONAL FEATURES OF THE UPGRADED LIFE CYCLE COST MODEL, EXPANDED FUEL CYCLE EMISSION DATA, AND VALUE/COST

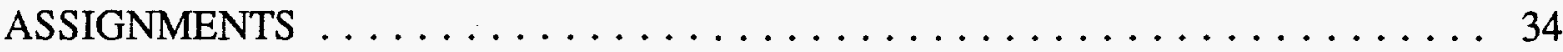

4.1 New Operational Features of the Life Cycle Cost Cycle Model . . . . . . . . . . 34

4.2 Expanded Fuel Cycle Emissions Data and Value/Cost Assignments . . . . . . . . 37

4.3 User's Manual . . . . . . . . . . . . . . . . . . . . 38

5.0 REFERENCE CASE ANALYSIS RESULTS $\ldots \ldots \ldots \ldots \ldots \ldots \ldots \ldots$

5.1 Reference $\mathrm{Car} /$ Van Cases with Conventional Fuel . . . . . . . . . . 40

5.2 Reference Car Case with Alternative Fuels . . . . . . . . . . . . 43

5.3 Reference Electric Car Case . . . . . . . . . . . . . . . . . 44

5.4 Reference Fuel Cell/Battery Car Case $\ldots \ldots \ldots \ldots \ldots \ldots \ldots \ldots \ldots$

6.0 SENSITIVITY ANALYSIS/IMPACT ASSESSMENT $\ldots \ldots \ldots \ldots \ldots \ldots .48$

6.1 Initial Rank Order of Case Results $\ldots \ldots \ldots \ldots \ldots \ldots \ldots \ldots \ldots 48$

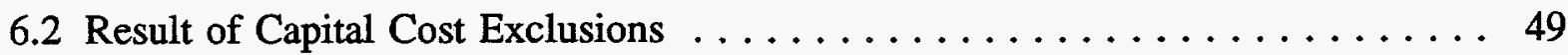

6.3 Energy Security Premium ...................... 50

6.4 Total Environmental Emissions $\ldots \ldots \ldots \ldots \ldots \ldots \ldots \ldots \ldots \ldots \ldots \ldots$

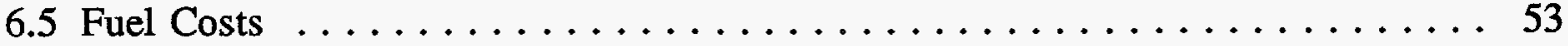

6.6 Specific Emission Types $\ldots \ldots \ldots \ldots \ldots \ldots \ldots \ldots \ldots \ldots \ldots \ldots \ldots$

7.0 CONCLUDING REMARKS $\ldots \ldots \ldots \ldots \ldots \ldots \ldots \ldots \ldots \ldots \ldots \ldots \ldots \ldots \ldots \ldots \ldots$

\section{APPENDICES}

Appendix A - Bibliography $\ldots \ldots \ldots \ldots \ldots \ldots \ldots \ldots \ldots \ldots \ldots \ldots \ldots \ldots \ldots \ldots \ldots$

Appendix B - Prior Bibliography $\ldots \ldots \ldots \ldots \ldots \ldots \ldots \ldots \ldots \ldots \ldots \ldots \ldots \ldots \ldots$

Appendix C - Embedded Data Sets $\ldots \ldots \ldots \ldots \ldots \ldots \ldots \ldots \ldots \ldots \ldots \ldots$

Appendix D - Reference Case Analysis Results ................. D-1

Appendix E - Acronyms and Abbreviations $\ldots \ldots \ldots \ldots \ldots \ldots \ldots \ldots \ldots \ldots$

Appendix F - LCC Model on Diskette $\ldots \ldots \ldots \ldots \ldots \ldots \ldots \ldots$ Tab F 
Table of Contents (Continued)

List of Tables

Table No.

Page

ES.1 Emissions Externality Costs $\ldots \ldots \ldots \ldots \ldots \ldots \ldots \ldots \ldots \ldots \ldots \ldots$

ES.2 Total Life Cycle Costs - Reference Car Case . . . . . . . . . . . . . . . . . . 4

ES.3 Comparative Life Cycle Costs Data (Relative Values) . . . . . . . . . . . . 6

2.1 Greenhouse Gas Emission Data $\ldots \ldots \ldots \ldots \ldots \ldots \ldots \ldots \ldots \ldots \ldots$

2.2 Price Trends in Crude Oil and Unleaded Gasoline . . . . . . . . . . . . 23

3.1 Hydrogen PEM Fuel Cell Characteristics @ 3.4 Atmospheres ........... 28

3.2 Hydrogen Storage System Characteristics $\ldots \ldots \ldots \ldots \ldots \ldots \ldots \ldots \ldots \ldots \ldots$

3.3 Hydrogen Fuel Characteristics . . . . . . . . . . . . . . . . . . 29

3.4 Characteristics of a Hydrogen PEMFC/Battery-Powered Car . . . . . . . . . 31

3.5 LCC Results for a Hydrogen PEMFC/Battery-Powered Car . . . . . . . . . . 32

3.6 Characteristics of a Hydrogen PEMFC/Battery-Powered Van . . . . . . . . . 33

3.7 LCC Results for a Hydrogen PEMFC/Battery-Powered Van . . . . . . . . . 33

5.1.1 Total Life Cycle Costs - Reference Car . . . . . . . . . . . . . . . . . 41

5.1.2 Total Life Cycle Costs Reference Cases - Cars and Vans Conventional Gasoline Fuel/Conventional ICE Engine . . . . . . . . . . . . . . . . . . 42

5.2 Total Life Cycle Costs Reference Car with Various Fuels . . . . . . . . . . . . 44

5.3 Total Life Cycle Costs Reference Electric Car Case . . . . . . . . . . . . . . 45

5.4 Total Life Cycle Costs PEM Reference Case Fuel Cell/Battery Cars . . . . . . 47

6.1 Comparative Life Cycle Costs Data (Absolute Values) . . . . . . . . . . . . . 52

6.2 Comparative Life Cycle Costs Data (Relative Values) . . . . . . . . . . . 52

$6.3 \quad$ Life Cycle Costs Altered Values $\ldots \ldots \ldots \ldots \ldots \ldots \ldots \ldots \ldots \ldots$

$6.4 \quad$ Avoided Costs Comparative Values ...................... 54

\section{List of Figures}

Figure No.

Page

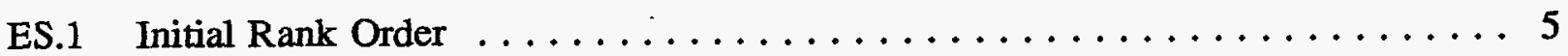

6.1 Initial Rank Order Listing $\ldots \ldots \ldots \ldots \ldots \ldots \ldots \ldots \ldots \ldots \ldots$

6.2 Revised Rank Order Listing . . . . . . . . . . . . . . . . . 49

6.3 Rank Order Listing with Additional Parameters ............... 51 


\section{EXECUTIVE SUMMARY}

This report presents the results of the further development and testing of the Life Cycle Cost (LCC) Model previously developed by Engineering Systems Management, Inc. (ESM) on behalf of the U.S. Department of Energy (DOE) under Contract No. DE-AC02-91CH10491.

The Model incorporates specific analytical relationships and cost/performance data relevant to internal combustion engine (ICE) powered vehicles, battery powered electric vehicles (BPEVs), and fuel cell/battery-powered electric vehicles (FCEVs). The Model is structured around twelve integrated modules as shown in the diagram below.

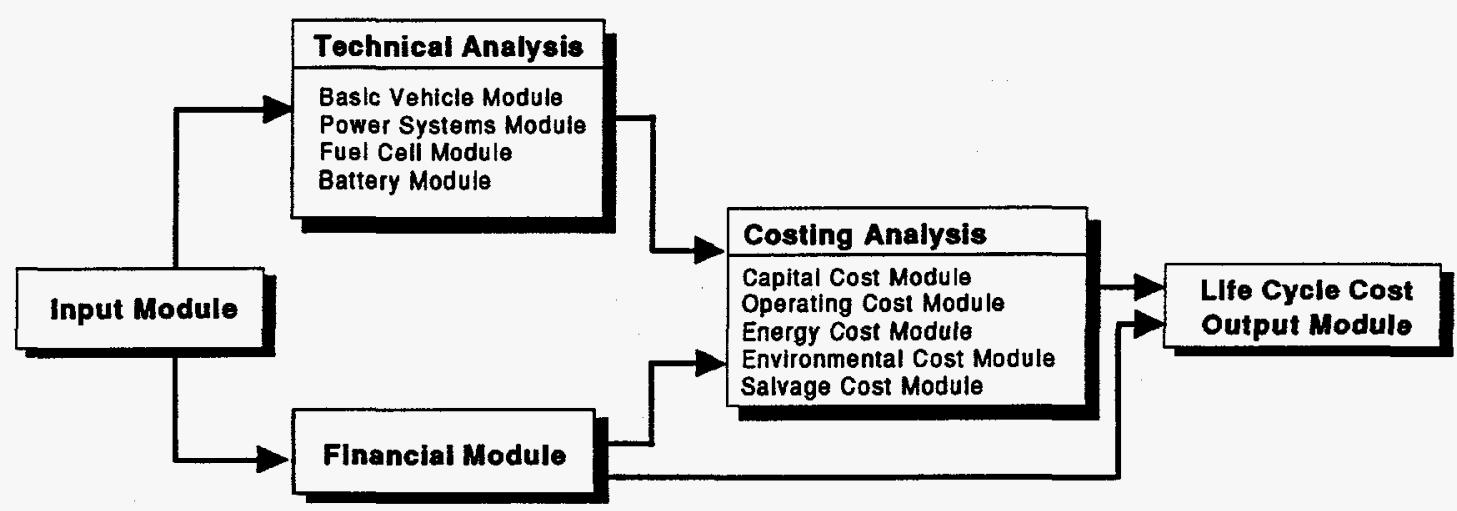

The original Model was used for performing comparative analysis between conventional gasoline and diesel fueled ICE vehicles, and fuel cell/battery-powered vehicles using either phosphoric acid fuel cells (PAFC) or proton exchange membrane fuel cells (PEMFC). It included the following fuel options:

ICEs:

- Gasoline

- Reformulated Gasoline (RFG)

- Diesel

- Reformulated Diesel

- Ethanol (E100)

- $\quad 85 \%$ Methanol/15\% Gasoline Blend (M85)

- Compressed Natural Gas (CNG) 
Fuel Cells:

- Ethanol (E100)

- Methanol (E100)

The prior work analyzed seven base vehicle configuration cases with a total of 21 vehicle class/powertrain/fuel combinations.

The specific emissions included in the original Model, as a life cycle cost element, were nitrogen oxides $\left(\mathrm{NO}_{\mathrm{x}}\right)$, hydrocarbons $(\mathrm{HC})$ and carbon monoxide $(\mathrm{CO})$. The costing and inclusion of these externalities in the life cycle analysis indicated that they could have monetary significance on a par with other life cycle elements, for purpose of comparative evaluation of alternative systems. Accordingly, the present work under contract No. DE-AC02-93CE50212 expanded and further refined this LCC-oriented environmental analysis by survey of the literature and selection of additional emissions factors for inclusion in the Model. The selected additions to $\mathrm{CO}, \mathrm{NO}_{\mathrm{x}}$, and HC were:

- Greenhouse Gases (GHGs), in terms of carbon dioxide $\left(\mathrm{CO}_{2}\right)$ equivalence;

- Sulfur Dioxide $\left(\mathrm{SO}_{2}\right)$;

- Particulate Matter (PM); and

- Toxics, including aldehydes, and the benzene, toluene and xylene (BTX) class of aromatics.

The Model allocates the cost of these "externalities" in terms of avoided costs. Table ES.1 summarizes these costs as they are represented in the Model.

The Model was also expanded to include the economic quantification of the impact of the higher volume of crude oil imports expressed by an incremental "national security premium" cost. The default value in the Model is $\$ 25.00$ per barrel of crude oil or $\$ 0.275$ per gallon of gasoline.

In addition, the timing of the HR-776 - The Energy Policy Act of 1992, Section 2026, had required DOE to look into the feasibility of utilization of hydrogen-fueled fuel cell/battery propulsion systems for vehicle applications. As a result, ESM included an LCC analysis of hydrogen-fueled proton exchange membrane (PEM) fuel cell/battery-powered cars and vans in 
Table ES.1: Emissions Externality Costs

\begin{tabular}{|l|c|}
\hline Emissions Component & Cost (1990\$ per ton) \\
\hline \hline Hydrocarbons $(\mathrm{HC})$ & $\$ 10,000$ \\
\hline Carbon Monoxide $(\mathrm{CO})$ & $\$ 850$ \\
\hline Nitrogen Oxides $\left(\mathrm{NO}_{\mathbf{x}}\right)$ & $\$ 5,000$ \\
\hline $\mathrm{CO}_{2}$ Equivalence & $\$ 16$ \\
\hline Sulfur Dioxide $\left(\mathrm{SO}_{2}\right)$ & $\$ 450$ \\
\hline Particulate Matter $(\mathrm{PM})$ & $\$ 4,500$ \\
\hline Aldehydes & $\$ 2,000$ \\
\hline BTX & $\$ 2,000$ \\
\hline
\end{tabular}

the present work. Finally, ESM validated and refined the LCC Model in order that outputs can sustain peer review and be used for decisionmaking purposes.

\section{Model Improvements}

Various modifications were made to the Model under the current work including the following:

- Conversion of software platform from Excel ${ }^{\oplus}$ to Quattro Pro for Windows ${ }^{\circledast}$ in order to achieve greater flexibility in design and use;

- Complete revalidation and adjustment as required of all equations and data previously incorporated in the Model;

- Expansion and revision of included data on fuel cycle emissions;

- Expansion and revision of included data on the economic value/cost of such emissions;

- Addition of a hydrogen-fueled PEMFC/battery-powered vehicle to the set of vehicles included for analysis; and

- Addition of user-friendly dialog boxes and a speed bar interface to facilitate case selection, data input, and Model operation.

In fact, the Model is sufficiently user-friendly that a user's manual is almost unnecessary. 
As an example of the cost component details contained in the current version of the Model, the Reference Car Case with a total life cycle cost of $\$ 35,378$ is shown in Table ES.2. This case is based on:

- Model default values;

- Conventional ICE engine;

- Car body type;

- Automatic transmission; using

- Conventional Gasoline.

Table ES.2: Total Life Cycle Costs - Reference Car Case

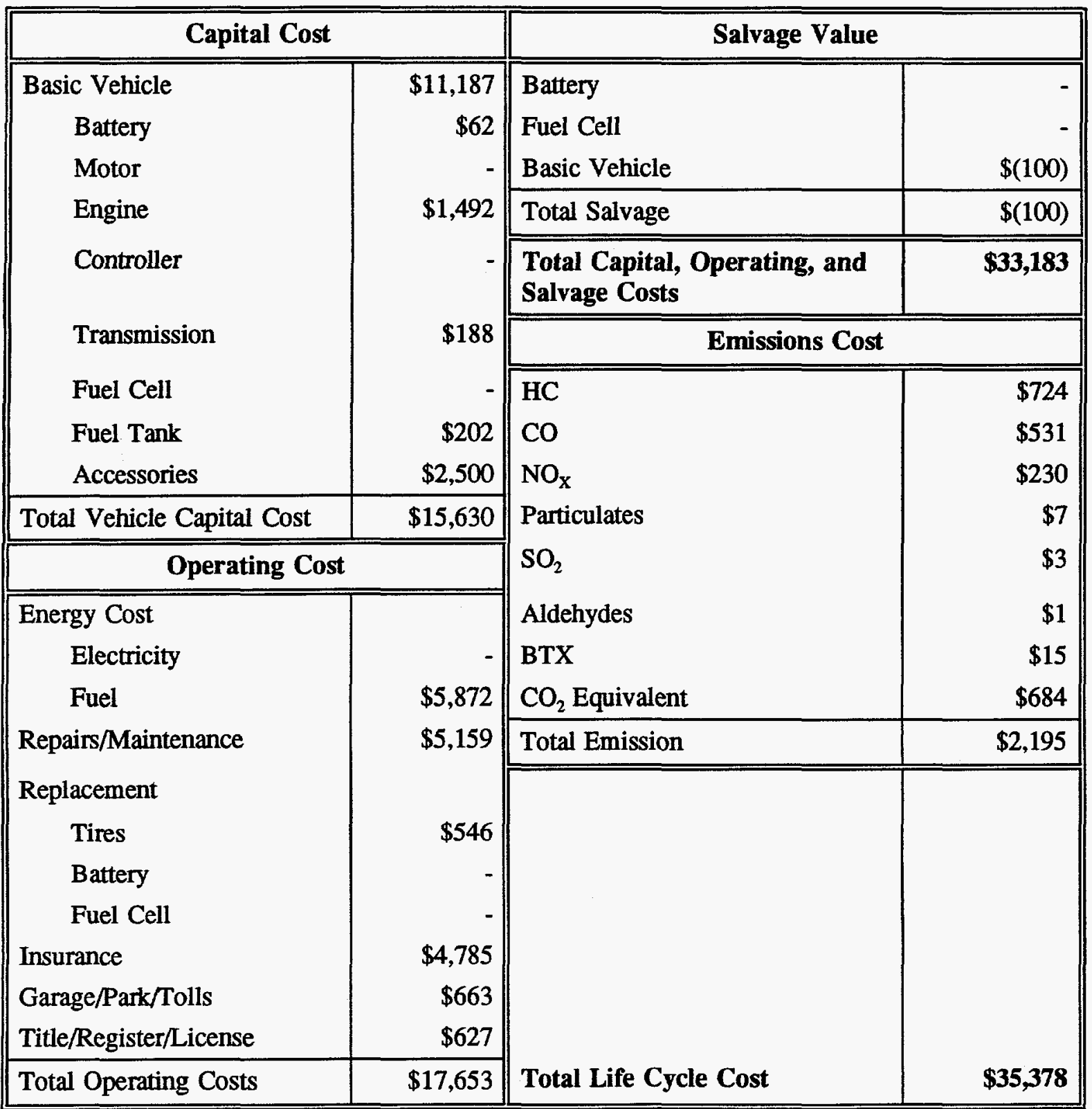


The user can obtain this case result and associated details by selecting the RESTORE DEFAULTS bar on the spreadsheet speedbar, selecting the CHOOSE VEHICLE bar, and then selecting the appropriate descriptions on the two dialogue boxes which are offered for this purpose.

Fourteen cases were analyzed as part of this stage of Model development. The Model input and output screens for each case are presented in Appendix D.

\section{Results}

The results for the Reference Vehicles and Default Assumptions of the Model in terms of the rank order listing are shown in Figure ES.1. All of the ICE cases, and the Reference Electric Vehicle, are within plus or minus 10 percent of the ICE - (Reformulated or Conventional) Gasoline current technology case. Since it is doubtful that advanced technology estimates are accurate within plus or minus 10 percent, this is equivalent to saying that there is no clear basis on which to judge the actual relative merits of those developmental concepts which are within this error band.

Figure ES.1: Initial Rank Order

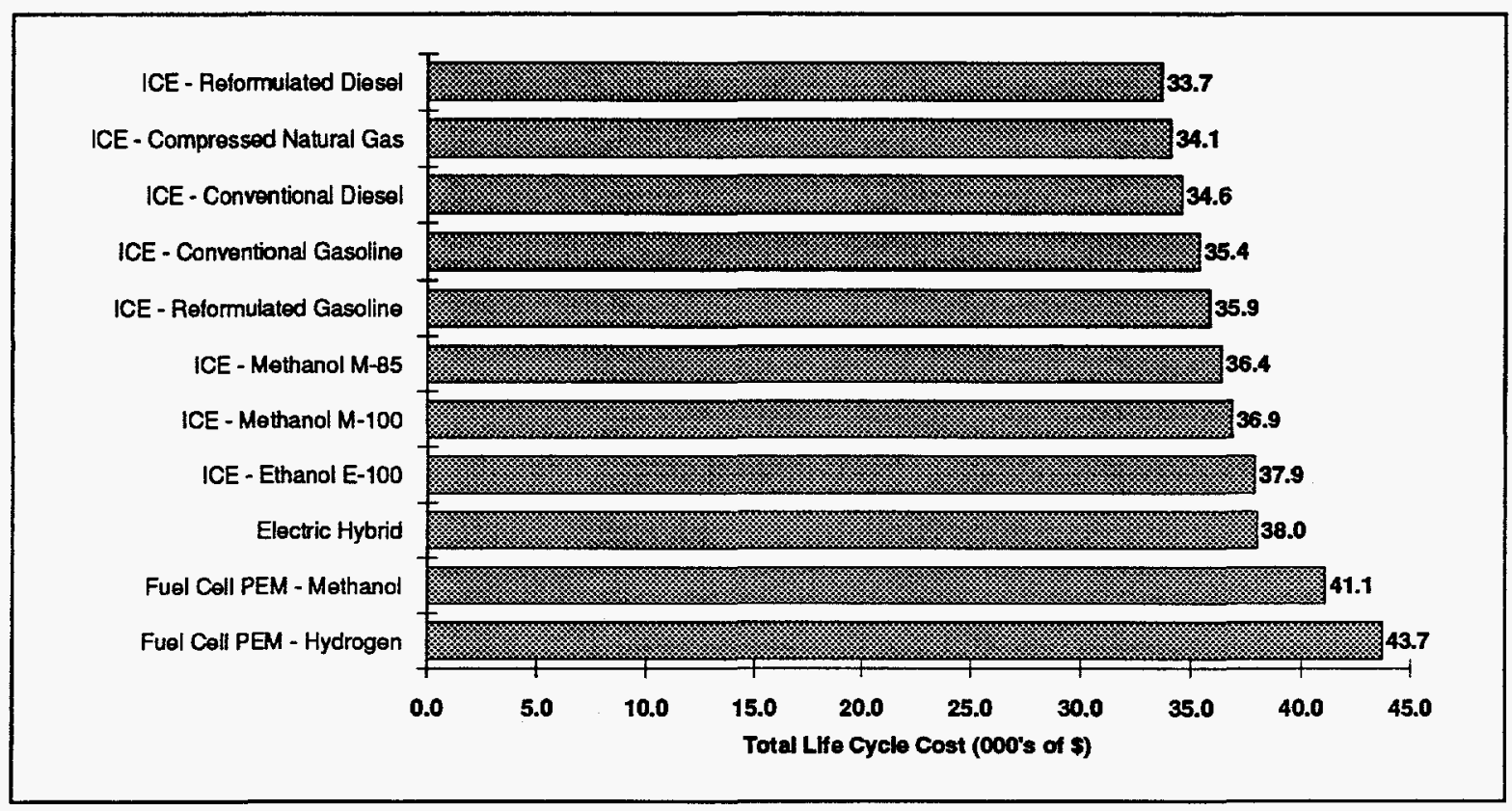


For the Fuel Cell PEM Vehicles, which are outside the 10 percent range, it is understood that these concepts are still in the early stages of development, as compared to the Alternative - Fuel ICE Vehicle. Accordingly it should be noted that the differential life cycle cost of some $\$ 6,000-$ $\$ 8,000$ (relative to the ICE - gasoline cases) is only about a 20 percent premium. A cost reduction of this magnitude, as the result of successful $R \& D$, is a credible target.

\section{Sensitivity Analysis}

The sensitivity analysis showed how the Model can be used for decisionmaking purposes. For example, a sensitivity test for avoided costs considered as an integral set, examines how rankings change if all of the established penalties (including the energy import premium) were twice their default values. Rather than all eleven vehicle/fuel types, one focuses for simplicity on five: conventional gasoline, compressed natural gas, ethanol, electric and the hydrogen fuel cell. These results are presented in Table ES.3.

Table ES.3: Comparative Life Cycle Costs Data (Relative Values)

\begin{tabular}{||l|c|c|c||}
\hline & \multicolumn{3}{|c|}{$\begin{array}{c}\text { Life Cycle Ranking } \\
\text { (Capital Excluded) }\end{array}$} \\
\cline { 2 - 4 } \multicolumn{1}{|c|}{ Vehicle Type/Fuel } & $\begin{array}{c}\text { No Emission } \\
\text { Penalties }\end{array}$ & $\begin{array}{c}\text { Default } \\
\text { Avoided Costs }\end{array}$ & $\begin{array}{c}\text { Double } \\
\text { Default } \\
\text { Values }\end{array}$ \\
\hline \hline ICE - Conventional Gasoline & 1 & 3 & $3-4$ \\
ICE - Compressed Natural Gas & 3 & 2 & 2 \\
ICE - Ethanol E-100 & 4 & 4 & $3-4$ \\
Electric & 2 & 1 & 1 \\
Fuel Cell PEM - Hydrogen & 5 & 5 & 5 \\
\hline
\end{tabular}

In this example, natural gas and electric vehicles appear superior to conventional gasoline when default values of avoided costs are considered. Hence, the inclusion of avoided costs leads to a significant result. Next, when the value of these costs are doubled, conventional gasoline vehicles appear even worse. However, much larger (and therefore not highly credible) changes in avoided costs would be needed before the cleanest fuels (biofuel ethanol and hydrogen) would appear economically competitive with either natural gas or electric fuels, even though these latter 
concepts do indeed release some undesirable emissions.

This sensitivity test reinforces the earlier conclusion that selected major R\&D targets for the cleaner fuel concepts are associated with reducing the cost of fuel for ethanol, and reducing both the fuel cost and component weight and/or capital cost for the hydrogen fuel cell.

\section{CONCLUDING REMARKS}

The Model has the capability to explore a variety of comparative policy issues relating to costs, benefits and R\&D targets. Additional features can readily be incorporated to examine still other questions and issues.

For example, in order to facilitate user control and conduct sensitivity studies of other-thandefault fuel costs, an entry for a factor by which to multiply such default values was created on the Other Inputs dialog box.

The use of Embedded Data Sets which the user may overwrite (thus providing for easy updating of the Model), and the open architecture of the system (thus providing for future representation of any subarea in additional detail without having to modify other parts of the Model) should allow the Model to retain both currency and validity over time. The Embedded Data Sets should be routinely updated for this purpose. The current values of the Embedded Data Sets are shown in Appendix C.

The life cycle cost sensitivity analysis has identified various key elements for comparative analysis. These should now be modeled and examined in greater detail. Future versions could also incorporate representations of the R\&D process (steps, cost and time) estimated to be required to achieve the target performance and cost objectives. The inclusion of probability features would enhance the ability to explore the value of alternative funding levels for the various R\&D targets. The benefit information in the Model is for a single vehicle lifetime. This information needs to be combined with penetration curves to evaluate absolute benefits and to allow the calculation of benefit/cost ratios for R\&D programs. 


\subsection{INTRODUCTION}

This report augments the development and testing of the Life Cycle Cost (LCC) Model previously accomplished by Engineering Systems Management, Inc. (ESM) on behalf of the U.S. Department of Energy (DOE) under Contract No. DE-AC02-91CH10491. The preliminary results of the LCC Model concluded that incorporation of environmental costs (associated with the vehicle propulsion systems' air emissions resulting from the fuel combustion) have a major impact on the relative economic ranking of alternative vehicle propulsion systems. In addition, the timing of the HR-776 - The Energy Policy Act of 1992, Section 2026, had mandated DOE to look into the feasibility of utilization of hydrogen-fueled fuel cell/battery propulsion systems for vehicle applications. As a result, the present work, under Contract No. DE-AC0293CE50212, was undertaken to focus upon the following:

- Expand the analysis of the environmental component emissions allocations, basis of cost assignments, time relative impacts of technology and regulatory development, and sensitivities to the LCC results for all vehicle classes;

- Perform LCC analysis of hydrogen-fueled proton exchange membrane (PEM) fuel cell/battery-powered cars and vans;

- Validate and refine the LCC Model to the point that outputs can sustain peer review and be used for decisionmaking purposes.

The work reported herein expands the capabilities of the Alternative Transportation Systems Life Cycle Cost Model which was developed in a preliminary form earlier. The Model incorporates specific analytical relationships and cost/performance data relevant to internal combustion engine (ICE) powered vehicles, battery powered electric vehicles (BPEVs), and fuel cell/battery-powered electric vehicles (FCEVs). The Model is structured around twelve integrated modules as shown in the diagram below.

The original Model was used to performing comparative analysis between conventional gasoline and diesel fueled ICE vehicles, and fuel cell/battery-powered vehicles using either phosphoric acid fuel cells (PAFC) or proton exchange membrane fuel cells (PEMFC). It included the following fuel options: 


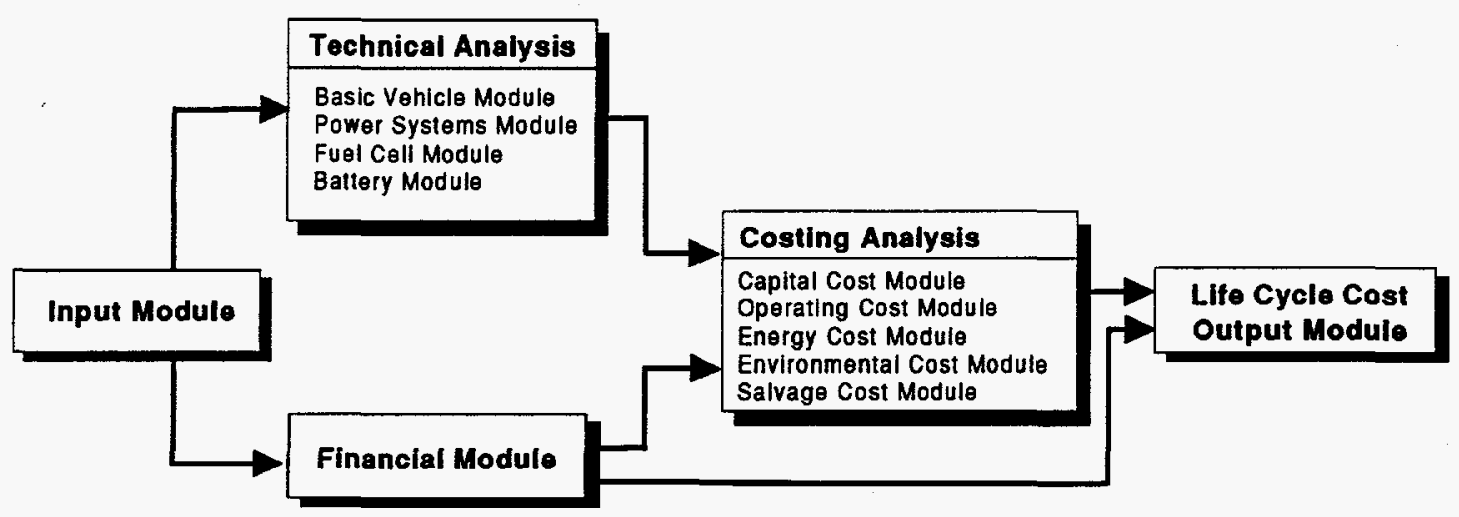

ICEs:

- Gasoline

- Reformulated Gasoline (RFG)

- Diesel

- Reformulated Diesel

- Ethanol (E100)

- $\quad 85 \%$ Methanol/15\% Gasoline Blend (M85)

- Compressed Natural Gas (CNG)

Fuel Cells:

- Ethanol (E100)

- Methanol (E100)

The prior work analyzed seven base vehicle configuration cases with a total of 21 vehicle class/powertrain/fuel combinations.

The specific emissions included in the original Model, as a life cycle cost element, were nitrogen oxides $\left(\mathrm{NO}_{\mathrm{x}}\right)$, hydrocarbons $(\mathrm{HC})$ and carbon monoxide $(\mathrm{CO})$. The costing and inclusion of these externalities in the life cycle analysis indicated that they could have monetary significance on a par with other life cycle elements for purpose of comparative evaluation of alternative systems. Accordingly, the present work expanded and further refined this LCC-oriented environmental analysis by survey of the literature and selection of additional emissions factors for inclusion in the Model. The selected additions to $\mathrm{CO}, \mathrm{NO}_{\mathrm{x}}$, and $\mathrm{HC}$ were: 
- Greenhouse Gases (GHGs), in terms of carbon dioxide $\left(\mathrm{CO}_{2}\right)$ equivalence;

- Sulfur Dioxide $\left(\mathrm{SO}_{2}\right)$;

- Particulate Matter (PM); and

- Toxics, including aldehydes, and the benzene, toluene and xylene (BTX) class of aromatics.

The present work incorporates the above-mentioned additional emission constituents and allocates them associated externalities costs as a function of avoidance costs. The concept of avoided cost is used to estimate the cost of controlling or avoiding the emissions in order to minimize or prevent damage.

The life cycle cost data for buses and heavy duty vehicle class was found to be sparse, incomplete and sometimes in conflict in the literature reviewed. At other times, the emissions data for this vehicle class did not appear to possess sufficient level of cross-detail or depth necessary to support selection of data points for the Model. As a result, the present life cycle cost analysis includes only cars and vans and not buses.

The Final Report is organized into the following sections. Section 1.0, Introduction, highlights the background of the present study and focuses on various issues addressed in this report. Section 2.0 contains detailed documentation of the expanded environmental analyses of the upgraded Life Cycle Cost Model, including a description of the methodology used for selecting additional emission cases and associated externalities costs. Section 3.0 discusses pertinent characteristics of the Life Cycle Cost Model for hydrogen proton exchange membrane fuel cell/battery-powered vehicles and performs a detailed life cycle cost analysis for both cars and vans. Section 4.0 describes the new operational features of the upgraded Model, including expanded fuel cycle emission data and value/cost assignments. This section also addresses userfriendly features of the Model. Section 5.0 provides cost analysis for various reference car and van cases under varying monetary, environmental and other parameters. Section 6 provides the results of sensitivity analysis/impact assessments for pertinent reference vehicle cases. Finally, Section 7.0 provides some concluding remarks that can be drawn from the analyses of the case esults conducted. A functional copy of the LCC Model is included on diskette (Appendix F). 


\subsection{General Approach}

ESM conducted a comprehensive literature search of work done by government and private sectors in this area, since the completion of the prior work in November 1992. This search generated over 120 studies which were carefully reviewed and evaluated against the backdrop of present scope of work. After a systematic evaluation, a total of 34 studies were selected to be used for the present effort (Appendix A). Each study was carefully reviewed and analyzed to reflect incorporation of pertinent relevant information through the:

- Conduct of environmental analysis by analyzing the completeness as well as comparability of environmental costs. This included formulation of basis for cost assignment of various emissions and other environmental impacts including the development of reasonable uncertainty ranges for each impact measured. This took into account the impact of time on relative values and ranges for these impact, including changes in technology (e.g., increased energy efficiency, enhanced emissions control systems, etc.), changes in environmental standards (arising from the existing environmental regulatory legislation, such as Clean Air Act Amendments of 1990), and changes in fuel supply.

- Conduct of LCC analysis for hydrogen-fueled PEMFC/Battery-powered vehicles by performing a detailed review and analysis of existing data on peripheral, cost, performance, and emission characteristics of cars and vans with initial emphasis on the fuel storage systems. This was done for the purpose of modifying the LCC Model to include hydrogen-fueled vehicles analysis capabilities.

The existing Life Cycle Cost Model was upgraded, refined and developed for continuous updatings, as desirable, to be used as an effective policy tool in the decisionmaking processes. To demonstrate the new LCC Models capabilities, 14 vehicle class/propulsion system configuration cases were evaluated for this work and are reported in Section 5.0 (case runs are contained in Appendix D. A sensitivity analysis was performed with the results are presented in Section 6.0.

For the benefit of the reader, a bibliographical listing of the literature used for the earlier study is provided in Appendix B. 


\subsection{Interim Reports}

During the course of the present work effort, three interim reports were generated and submitted to DOE as a part of the contractual requirements These included:

- Expanded Environmental Analysis for the Alternative Transportation Systems Life Cycle Cost Model, Interim Report Task 1 (Submitted May 31, 1994).

- Analysis of Hydrogen-Fueled PEMFC/Battery-Powered Vehicles using the Alternative Transportation Systems Life Cycle Cost Model: Interim Report: Task 2 (Submitted June 30, 1994).

- Upgraded Life Cycle Cost Model for Alternative Transportation Systems, Interim Report - Task 3 (Submitted August 31, 1994).

The present report incorporates, in abstract, the results of the three above-mentioned interim reports and discusses results of additional information and data generated since. 


\subsection{EXPANDED ENVIRONMENTAL ANALYSIS OF THE ALTERNATIVE TRANSPORTATION SYSTEM LIFE CYCLE COST MODEL}

\subsection{Methodology for Selection of Additional Emission Cases}

The LCC Model developed earlier by ESM, Inc. for DOE (Reference 1) incorporated quantitative estimates of transportation fuel cycle emissions and their costs as part of total system costs over the life cycle of the cars, vans, and buses. The specific emissions included nitrogen oxides $\left(\mathrm{NO}_{\mathrm{x}}\right)$, hydrocarbons $(\mathrm{HC})$, and carbon monoxide $(\mathrm{CO})$. The costing and the inclusion of these externalities in the life cycle analysis indicated that they could have monetary significance on a par with other life cycle elements for purposes of comparative evaluation of alternative systems.

The emissions incorporated into the initial version of the LCC (Reference 1) were selected for their significance as smog precursors $\left(\mathrm{NO}_{\mathrm{x}}\right.$ and $\mathrm{HC}$ ) and deleterious health effects $(\mathrm{CO})$. In addition, the DOE had proposed specific economic values to be assigned to these externalities.

In preparation for the conduct of the expanded scope of environmental analysis of the LCC Model, a survey of the extensive literature on transportation systems cross-technology comparisons indicated that a more complete set of emissions characterizations was needed to fully assess comparative environmental impacts. The set of emissions characterizations would have to consist of the following:

- Greenhouse gases which include methane $\left(\mathrm{CH}_{4}\right)$, carbon dioxide $\left(\mathrm{CO}_{2}\right)$, nitrous oxide $\left(\mathrm{N}_{2} \mathrm{O}\right.$ ), volatile organic compounds (VOC), and chlorofluorocarbons (CFC) from automotive air conditioning systems;

- Acid rain precursors, primarily sulphur oxides $\left(\mathrm{SO}_{\mathrm{x}}\right)$ and nitrogen oxides $\left(\mathrm{NO}_{x}\right)$;

- Other gases or volatile compounds generating deleterious health effects, such as formaldehyde (and other aldehydes), methanol, and carbon monoxide (CO);

- Solid emissions generating deleterious health effects, such as Respirable Suspended Particulates (particularly those below 10 microns in size) which embed themselves in the lungs; and

- Toxic compounds such as benzene, toluene, and xylene (BTX). 
Some of the above compounds can be classified into more than one category. For example, some VOCs (also delineated as Reactive Organic Gases - ROG or Hydrocarbons - HC or Non-Methane Organic Compounds - NMOC) may be seen as greenhouse gases, smog precursors, toxic chemicals, and/or compounds generating less severe but still deleterious health effects. Some of these compounds are products of combustion, others of evaporative losses associated with fuel volatility.

\subsubsection{Greenhouse Gases}

Greenhouse gases (GHG) are included as a set because of their significance to President's Global Climate Change initiatives, the possible high costs of mitigation, the large fraction of such emissions from the transportation sector, the significant differences in these emissions among transportation alternatives, and the substantial number of recent studies available which provide good summary comparative data.

The impact of CFCs within this set was considered and then excluded from further consideration because they are being phased out over time, and because their impact does not necessarily differ as a function of vehicle fuel source.

The main GHG is $\mathrm{CO}_{2}$. Some 25 percent of U.S. $\mathrm{CO}_{2}$ emissions are generated from motor vehicles, and the importance of this source is increasing as the number of motor vehicles as well as vehicle miles traveled increases annually (Reference 2 ). While $\mathrm{CO}_{2}$ will contribute about half of future global warming, the other GHGs, taken together, are of equal significance (Reference 3). Accordingly, it deems useful to analyze the full set, and express the emissions results in terms of metric tons of $\mathrm{CO}_{2}$ equivalent (using the respective radiation forcing of the other gases to normalize them to the $\mathrm{CO}_{2}$ equivalent basis).

In terms of the respective sources of the GHGs from automotive use (across both the full fuel cycle and vehicle manufacture), some 72 percent come from tail pipe emissions, 18 percent from the remainder of the fuel cycle, and 10 percent from the manufacturing process (Reference 4). 
Table 2.1 presents the greenhouse emission data selected for use in the LCC Model from References 3 and 4.

\subsubsection{Nitrogen Oxide, Carbon Monoxide, and Sulfur Oxides}

Nitrogen oxide, carbon monoxide, and hydrocarbons continue to be included, as before, but now with updated data. Motor vehicles contribute more than half the $\mathrm{CO}$, almost one-third of the $\mathrm{NO}_{\mathrm{x}}$, and more than one-quarter of the $\mathrm{HC}$ in the U.S. air emissions (Reference 5). Hydrocarbon emissions are presented in Section 2.1.5. Sulfur oxides are included for completeness as an acid precursor and because data is readily available, although it is of lesser significance as compared to other emissions. The following values (units in grams/kilometer) were selected:

Table 2.1: Greenhouse Gas Emission Data

\begin{tabular}{|c|c|c|c|}
\hline \multirow[b]{2}{*}{ Vehicle and Fuel (Source) } & \multicolumn{3}{|c|}{$\begin{array}{c}\text { Greenhouse Gas Emissions } \\
\text { Equivalent/Kilometer } \\
\text { (Grams of } \mathrm{CO}_{2} \\
\text { Equivalent/Kilometer) }\end{array}$} \\
\hline & $\begin{array}{l}\text { Full Cycle } \\
\text { Plus }^{4}\end{array}$ & $\begin{array}{l}\text { Full Fuel } \\
\text { Cycle }^{3}\end{array}$ & Tail Pipe $^{3}$ \\
\hline $\begin{array}{l}\text { Light Duty Internal Combustion Engine (ICE) } \\
\text { Gasoline }\end{array}$ & 260 & & \\
\hline Reformulated Gasoline (RFG) & 263 & 307 & 209 \\
\hline Diesel & 210 & & \\
\hline Compressed Natural Gas (CNG) & 231 & 264 & 168 \\
\hline Methanol (NG) & 250 & 303 & 173 \\
\hline Methanol (Wood) & 84 & & \\
\hline Ethanol (Corn) & 260 & & \\
\hline Ethanol (Wood) & 82 & 82 & 32 \\
\hline $\mathrm{H}_{2}$ (Nuclear) & 77 & & \\
\hline Electric (U.S.) & 244 & 317 & \\
\hline
\end{tabular}


- For light duty vehicles using gasoline, the choice was Reference 19 as follows: $\mathrm{CO}$ at $1.4, \mathrm{NO}_{\mathrm{x}}$ at 0.22 , and $\mathrm{SO}_{2}$ at zero.

- For light duty vehicles using reformulated gasoline, the values were selected from Reference 6 as follows: $\mathrm{CO}$ at $3.8, \mathrm{NO}_{x}$ at 0.28 and $\mathrm{SO}_{2}$ at 0.035 , all in grams per kilometer.

- For light duty vehicles using $\mathrm{CNG}$, the choice was Reference 7 with $\mathrm{CO}$ at $0.08, \mathrm{NO}_{\mathrm{x}}$ at 0.36 and $\mathrm{SO}_{2}$ at zero.

- For light duty vehicles using ethanol, the choice was Reference 8 with $\mathrm{CO}$ at $1.06, \mathrm{NO}_{\mathrm{x}}$ at 0.12 , and $\mathrm{SO}_{2}$ at 0.002 .

- For light duty vehicles using M85 and neat methanol, the preference was to select Reference 9 for methanol 100, and to obtain the result for M85 by calculating a mathematical blend. This approach produced $\mathrm{CO}$ at $1.06, \mathrm{NO}_{\mathrm{x}}$ at 0.38 and $\mathrm{SO}_{2}$ at zero for neat methanol; and $\mathrm{CO}$ at $1.47, \mathrm{NO}_{\mathrm{x}}$ at 0.365 and $\mathrm{SO}_{2}$ at 0.005 for $\mathrm{M} 85$.

- Only single data points from Reference 34 were found for light duty vehicles using M85 ( $\mathrm{CO}$ at $0.08, \mathrm{NO}_{\mathrm{x}}$ at 0.48 ) and $\mathrm{H}_{2}\left(\mathrm{CO}\right.$ at $0.06, \mathrm{NO}_{\mathrm{x}}$ at 0.41 ) and light duty electric vehicles (Reference 6) using the U.S. average ( $\mathrm{CO}$ at $0.04, \mathrm{NO}_{x}$ at 0.12 , and $\mathrm{SO}_{2}$ at 0.15 ). The data appeared reasonable in light of the other relevant information.

- For light duty diesels, the values from Reference 10 for diesel ( $\mathrm{CO}$ at $0.47, \mathrm{NO}_{\mathrm{x}}$ at 1.26$)$ and biodiesel ( $\mathrm{CO}$ at 0.13 and $\mathrm{NO}_{\mathrm{x}}$ at 1.22 ) fuels also appear to be in line with the other data available.

- Data on vans and heavy duty vehicles was both quite variable, limited in coverage, and not clearly related to comparable information on the other vehicles. Accordingly, it did not appear appropriate to use it to derive inputs for the LCC Model.

\subsubsection{Particulate Matter}

Particulate Matter (PM) was included because of the seriousness of the health effects involved, the existence of real differences in emission levels across technologies, the potential high cost of control, and the likelihood that standards in this area would be tightened in the future. A study presented to the American Lung Associated in 1991 targeted PM as responsible for 60,000 deaths for that year in the United States (more people than are killed in traffic accidents) (Reference 11). A 1993 update of this study substantiated a 26 percent difference in mortality in cities with high and low PM exposure, and suggested the need for tightened standards (Reference 12). 
The American Lung Association is active in pressing for change, and notes that 146 million Americans (more than 60 percent of the U.S. population) live in non-attainment areas for air quality generally, where populations are at risk to adverse health effects (Reference 13). PMs and other automobile emissions are particular targets because they are emitted at street level, and directly penetrate the lungs.

Data selected for $\mathrm{PM}_{10}$ for light duty ICE vehicles was as follows: Reformulated gasoline (0.01 gms $/ \mathrm{km})$ (Reference 6); methanol (0.01 gms $/ \mathrm{km})$ (Reference 6); and CNG (0.01 gms/brake HP Hour) (Reference 12). For light duty electric vehicles, the value selected was U.S. average of $0.025 \mathrm{gms} / \mathrm{km}$ (Reference 6). For light duty diesel vehicles, a value of $0.26 \mathrm{gms} / \mathrm{brake} \mathrm{HP}$ hour (Reference 10) was used for biodiesel a value of 0.19 gms HP Hour was used (Reference 10). For heavy duty vehicle internal combustion engines, $\mathrm{PM}_{10}$ emissions can be reasonably represented at 0.02 for CNG (References 14 and 16) and 0.04 for methanol (References 9, 14, 15, and 16), both values expressed in grams per brake horsepower hour. For heavy duty diesels, a value of 0.57 for diesel fuel (References 3,15, and 16) and a mid-range value of 0.15 for methanol (References 9 and 14) appeared appropriate, both values expressed in grams per brake horsepower hour.

\subsubsection{Toxics (Including Hydrocarbons)}

Toxics were included as a category because of their significant health threats and the potentially high cost of control. Benzene and formaldehyde are listed as two of the five most serious toxic chemicals in the air, as approximately 85 percent of air-borne benzene comes directly from motor fuel (Reference 17). There is no safe level of exposure to carcinogens such as benzene, and the Environmental Protection Agency has documented substantial relative increases in exposure that are transportation related (e.g., large cities versus rural areas, and car interiors in the California South Coast) (Reference 17). Increased formaldehyde exposure is, of course, linked to increased reliance on methanol as an alternative fuel. While reformulated gasoline will produce cleaner burning fuels, the benzene, toluene, and xylene (BTX) class of aromatic compounds are produced during combustion, and their generation can likely be avoided only by switching away from gasoline as a fuel (Reference 17). Separate accounting is maintained for the Toxics category for BTX-type emissions and for aldehydes. 
- For light duty vehicles, the data on non-methane organic compound (NMOC) emissions in Reference 18 for gasoline $(0.44-0.66 \mathrm{gms} / \mathrm{km})$ and RFG $(0.40 \mathrm{gms} / \mathrm{km})$ appeared sufficiently representative, and had the benefit of coming from a single source. The approximate mid-range values of $0.045 \mathrm{gms} / \mathrm{km}$ for the BTX fraction and $0.003 \mathrm{gms} / \mathrm{km}$ for aldehydes fraction also appeared to be reasonable.

- For light duty vehicles using CNG, the values in Reference 14, with NMOC at 0.12 gms $/ \mathrm{km}, \mathrm{BTX}$ at zero, and aldehydes at a midrange $.0065 \mathrm{gms} / \mathrm{km}$ were selected.

- For light duty vehicles using ethanol, the selections were NMOC at $0.24 \mathrm{gms} / \mathrm{km}, \mathrm{BTX}$ at $0.009 \mathrm{gms} / \mathrm{km}$, and aldehydes at $0.018 \mathrm{gms} / \mathrm{km}$ (References 9,18 , and 19).

- For light duty vehicles using methanol and M85, the selections were based on Reference 14 for methanol with NMOC at $0.58, \mathrm{BTX}$ at 0.01 , aldehydes at 0.0080 and vaporized methanol at a midrange of 0.71 ; and results for M85 to be obtained by mathematical averaging with gasoline, giving NMOC at $0.56, \mathrm{BTX}$ at 0.015 , aldehydes at 0.007 and vaporized methanol at 0.60 . All units are in $\mathrm{gms} / \mathrm{km}$.

- References 6 and 10 provided single data point coverage $(0.05 \mathrm{gms} / \mathrm{km})$ of light duty fuel cell (methanol), electric $(0.02 \mathrm{gms} / \mathrm{km})$ (U.S. Average), diesel $(0.13 \mathrm{gms} / \mathrm{km})$ and biodiesel $(0.03 \mathrm{gms} / \mathrm{km})$.

\subsection{Cost Basis for Externalities, Associated Unit Costs for Emission Avoidance, and Other Considerations}

\subsubsection{Cost Basis for Externalities and Associated Unit Costs}

The approach used in the LCC analysis is to value externalities using an avoided cost methodology. The primary alternative is to use estimates of damage.

The concept of avoided cost attempts to estimate the cost of controlling or avoiding the emissions in order to minimize or prevent any damage. This is particularly appropriate in cases where there may be multiple sources, and where mitigation strategies may find that costs are different in terms of dealing with one source as compared to another. In addition, if economic nationality prevails, costs incurred (actually or potentially) to avoid should always be less than the threatened damage (otherwise it costs more to avoid than it does to accept the damage).

Dealing with avoided costs to value externalities also has the benefit of relating to real expenditures that are otherwise scheduled or required to be made. Savings are therefore intended 
to be real rather than hypothetical.

The social judgements necessary to define the degree and extent of avoidance are typically made through the regulatory process, and are therefore determined by public policy, not by the analyst.

Avoided cost to evaluate externalities has become increasingly common in recent years, particularly in the electric utility industry. Quantitative procedures, similar to those discussed subsequently in this study, are in use in California, Massachusetts, Missouri, Nevada, New Jersey, New York, and Wisconsin (Reference 20).

One key consideration, often overlooked in seeking to quantify avoided costs, is that the benefit earned by avoidance is typically greater than the average cost of avoidance. For example, if the concentration of a pollutant in the air is in excess of a desired standard, the policy actions to reduce its emission, given that a variety of sources may exist, will proceed from least costly to most costly. The average cost over this regime will be greater than the cost of the initial steps but lower than the cost of the final, most expensive, steps. Therefore, if the emission is avoided rather than removed, the value of the avoidance action is the savings of the final steps in the sequence of removal actions, not the average step.

Because of the interrelationship between degree of cleanup required, and the cost of the final cleanup steps, the appropriate avoided cost is a direct function of the tightness of the standard. The more extensive the cleanup required, the higher will be the costs of the final stage of that cleanup.

The two factors discussed above, namely that avoided costs are not appropriately estimated as average costs, and are direct functions of the standards to be achieved as well. The current degree of non-conformance to such standards, complicate their estimation. By these definitions, avoided costs for a given pollutant can readily differ from one region of the country to another, as well as between rural and urban areas. Nevertheless, the use of this approach still appears as the most objective technique available to quantify in economic terms those important differences in externalities associated with different technologies and fuels. 


\subsubsection{Greenhouse Gases}

The relationships between carbon taxes, as an economic forcing function, and greenhouse gas reductions have been extensively modeled. The results of these studies are selected as the best currently available basis by which to derive an avoided cost estimate for greenhouse gases. One such study by Jorgensen and Wilcoxen (reported in Reference 21) calculated a tax stabilizing at $\$ 60$ per ton carbon to reduce U.S. $\mathrm{CO}_{2}$ emissions to 80 percent of 1990 levels and maintain them there indefinitely. Another study (by the Congressional Budget Office (Reference 22)) used a value of $\$ 100$ per ton $C$. Reference 23 identifies this latter figure as a possible upper limit because renewable resources would likely be fully economically competitive at this level of carbon tax. Also, in testimony before public utility commission (Reference 22), externality values for $\mathrm{CO}_{2}$ emissions as high as $\$ 300$ per ton $\mathrm{CO}_{2}(\$ 82$ per ton $\mathrm{C}$ ) have been proposed. The National Conference on Environmental Externalities recommended a value of $\$ 50$ per ton $\mathrm{C}$ for power plant emissions as an externality measure (Reference 24). Based on these and related data points, the value of $\$ 60$ per ton $\mathrm{C}$ (or about $\$ 16$ per ton $\mathrm{CO}_{2}$ ) was selected.

\subsubsection{Nitrogen Oxides, Carbon Monoxide, and Sulfur Oxides}

DOE has previously used an avoided cost value of $\$ 300$ per ton $\mathrm{NO}_{\mathbf{x}}$ (Reference 25). Other estimates including those by the Gas Research Institute (GRI) vary between $\$ 200-2,000$ (Reference 26), public utility commission's testimony supporting values of $\$ 3,250-6,770$ (Reference 20) and from the California South Coast Air Quality District of over $\$ 25,000$ (Reference 20). Accordingly, based on the regulatory studies, a lower mid-range value of $\$ 5,000$ per ton $\mathrm{NO}_{\mathrm{x}}$ was selected.

Similarly for CO, the value in use by DOE is $\$ 300$ per ton (Reference 25). However, estimates by others include $\$ 500-1,000$ by the GRI (Reference 26 ), and $\$ 820-870$ by witnesses in public utility commission hearings (Reference 20 ). Accordingly, the approximately mid-range value of $\$ 850$ per ton CO from the latter reference was selected.

The approach for valuation of $\mathrm{SO}_{2}$ considers both regulatory testimony and the emissions trading market values derived from recent auctions of $\mathrm{SO}_{2}$ emissions rights in accordance with the Clean 
Air Act of 1990. Monetized control costs for $\mathrm{SO}_{2}$ in regulatory testimony have been proposed at $\$ 1560-1910$ generally and up to $\$ 19,000$ for the California South Coast (Reference 20). An independent GRI estimate ranges from $\$ 350-1800$ (Reference 26). On the other hand, trading allowances reported by the Energy Information Administration (Reference 27) were bid at prices up to $\$ 310$ for use in the year 2000 , whereas offers on the 1995 spot market were at a high of 1900 , and on the year 2000 advance market of $\$ 449$. These highs are viewed as more meaningful than the lows or averages because they represent more stringent cards of need and/or value.

The experience with trading allowances suggest that the utility industry has increasing confidence that actual $\mathrm{SO}_{2}$ mitigation costs will not be extreme. Accordingly, the year 2000 allowance high offer of (rounded) $\$ 4,450$ per ton $\mathrm{SO}_{2}$ was selected for use.

\subsubsection{Particulate Matter}

Regulatory estimates for particulate mitigation are $\$ 4,164$ per ton (Reference 20 ), whereas the National Conference on Environmental Externalities recommends a range of $\$ 2,360-4,720$ (Reference 24). Because particulate matter generated from transportation sources are potentially more harmful and difficult to mitigate, being emitted at street level, a value in the higher side of this range, $\$ 4,500$ per ton $\mathrm{PM}_{10}$ was selected.

\subsubsection{Toxics (Including Hydrocarbons)}

The avoidance value of toxics (BTX, aldehydes and methanol vapors) was estimated based on recent actions of the EPA to reduce industrial toxic emissions (Reference 28). Some 506,000 tons per year are expected to be removed at a capital investment (estimated by EPA) of $\$ 450$ million accompanied by continuing costs of $\$ 230$ million annually. If the capital investment is assumed to be associated with a 20 percent capital recovery factor as an annualized cost, then annual costs would approximate $\$ 90$ million plus $\$ 230$ million for a total of $\$ 320$ million, or a unit cost of $\$ 640$ per ton toxics reduced. The same reference cites an industry estimate of $\$ 1$ billion, about three times higher. Assuming that current actions will direct lowest cost remedies first, and that later additional remedies will rise in cost, the industry estimate is the preferred 
basis, leading to a selected value of $\$ 2,000$ for the LCC Model.

The DOE has previously used an avoided cost value of $\$ 3050$ per ton hydrocarbon (HC) for this type of emission (Reference 25). Regulatory testimony has placed this value at $\$ 5,500$ generally, and over $\$ 18,000$ in California (Reference 20 ). The GRI estimate ranges from $\$ 500-5,300$ (Reference 26). Studies by Resources for the Future (References 29) indicate that actual abatement strategies for reduction of Volatile Organic Compounds (VOC) generated in the transportation sector range in cost from $\$ 1,650-108,000$ per ton of VOC reduced, and that a currently "low-cost" strategy of accelerated vehicle retirement showed costs ranging from $\$ 4,000$ 5,000. The references cite views ascribed to the Environmental Protection Agency (EPA):

"In general, EPA considers any approach that costs less than $\$ 5000$ per ton of emissions reduced to be highly cost-effective; options that reduce VOCs for less than $\$ 10,000$ per ton are still considered reasonable."

Accordingly, given the likelihood that higher cost regulatory actions will likely be actually implemented, and should therefore be used to establish the avoided cost credit, the value of $\$ 10,000$ was selected for the LCC Model.

\subsubsection{National Security Premium}

The economic quantification of the impact of the higher volume of crude oil imports typically expressed by analysts as an implied add-on cost for such imports as a dollar value per barrel premium. There is little if any agreement on the appropriate magnitude of this premium (Reference 21). Annual costs associated with maintenance of defense costs and the Strategic Petroleum Reserve estimate at $\$ 50$ billion. If allocated against an import level of 7 million barrels per day, this would equate to $\$ 25$ per barrel imported crude. Reference 31 summarizes a variety of studies from the 1979-1988 period which have generated estimates as high as $\$ 50$ per barrel. Because the oil supply cartel appears to have weakened in the last decade, rather than strengthened, the more conservative estimate of $\$ 25$ per barrel is selected for the LCC Model.

In order to use this premium as an avoided costs, it is more convenient to translate it into a cents per gallon gasoline equivalent. This can be accomplished by using the data for annual crude oil 
and U.S. gasoline prices from Reference 32 as reproduced in Table 2.2. When this data is sorted and subjected to regression analysis, the derived relationship is that the gasoline price in dollars per gallon is equal to $\$ 0.6855$ plus the crude price in dollars per barrel times 0.022 . This relationship has an $\mathrm{R}$-squared correlation coefficient of 0.8673 , indicating a reasonably good fit. If the $\$ 25$ per barrel crude oil premium is multiplied by the 0.022 coefficient derived above, then divided by 2 to reflect an import level of half the total crude oil consumption, a resulting national security premium of $\$ 0.275$ per gallon of gasoline is calculated.

Table 2.2: Price Trends in Crude Oil and Unleaded Gasoline

\begin{tabular}{|c|c|c||}
\hline Year & $\begin{array}{c}\text { Crude Oil Domestic First Purchase } \\
\text { Price \$/bbl }\end{array}$ & $\begin{array}{c}\text { U.S. City Average Retail Price } \\
\text { for Unleaded Regular Gasoline } \\
\text { \$/gal }\end{array}$ \\
\hline \hline 1979 & 12.64 & 0.90 \\
\hline 1980 & 21.59 & 1.25 \\
\hline 1981 & 31.77 & 1.38 \\
\hline 1982 & 28.52 & 1.30 \\
\hline 1983 & 26.19 & 1.24 \\
\hline 1984 & 25.88 & 1.21 \\
\hline 1985 & 24.09 & 1.20 \\
\hline 1986 & 12.51 & 0.93 \\
\hline 1987 & 15.40 & 0.95 \\
\hline 1988 & 12.58 & 0.95 \\
\hline 1989 & 15.86 & 1.02 \\
\hline 1990 & 20.03 & 1.16 \\
\hline 1991 & 16.54 & 1.14 \\
\hline 1992 & 15.98 & 1.13 \\
\hline
\end{tabular}

\subsubsection{Data Uncertainties}

Emissions data for tailpipes are functions of driving cycle (all data in this report and the LCC Model are based on the Federal Test Procedure - FTP standard), vehicle, engine, catalyst, maintenance, mileage (use), and a host of similar factors. Cumulative emissions per mile depend on these factors plus other trip and driving factors such as total vehicle mile/traveled, number of 
cold starts (which generate greater emissions), idling, driving at low speeds in congested traffic situations and the like. Evaporative emissions are important contributors to total vehicle use emissions and reflect climate, refueling techniques and similar factors. The same make and model year cars may display different emissions under apparently similar conditions. Differences in usage and maintenance quickly increase the variability in data.

When tailpipe and evaporative emissions are expanded to include full fuel cycles, test data are replaced by calculations of probable emissions from fuel extraction, conversion and distribution. These additions can range from modest to extensive. The greenhouse gas emissions from a conventional gasoline car may show 73 percent associated with operation of the vehicle, 18 percent with fuel supply, and 10 percent with vehicle manufacture (Reference 4). On the other hand, the fuel production source and method for ethanol can alter the total greenhouse gas emissions from 82 grams $\mathrm{CO}_{2}$ equivalent per kilometer (wood as fuel source) to 260 (corn as fuel source) (Reference 4). Uncertainties are explicitly calculated and displayed in Reference 4. They vary by a few percent in the simplest cases to plus or minus 100 percent in more complex cases.

Returning to tailpipe emissions, even where standard test procedures are used, the data is highly variable. Since the emphasis here is on cross-comparability of fuels and technologies, more than on absolute data values, the most useful results for these purposes are those which report such comparative results as achieved by a single researcher. Otherwise, it is desirable to look to a large body of data which displays general agreement and internal consistency. In this report, the first approach was used to select values for greenhouse gas emissions, and the second to select values for the other emissions.

The variability of individual data points is well illustrated by the initial information on alternative fuel fleets (Reference 33). For a given single model year car, $\mathrm{CO}$ emission is grams per mile ranged from 1 to 7 . Efforts to analyze the data included the generation of regression parameters (Reference 33, Appendix 5, Table A.5-1). The value of $R$ squared for these equations show that 23 of the 29 equations have a correlation coefficient below 0.5 , indicating a low level of effective correlation. It should be recalled that these fleets are being managed and tested as an important source of experimental data. 
Similar variability and diversity in range is shown in the data tables presented in this report. A meaningful representation of statistical ranges of uncertainty for comparative purposes did not appear appropriate at this stage of data development.

The uncertainty in these values includes not only issues associated with cost estimation, but also issues of the degree to which mitigation measures might actually proceed, and, therefore, what activities or events should be included within the cost estimate.

Since the selected emissions and unit avoidance costs are combined to yield economic values for comparison across fuels and technologies, the application of the LCC methodology should include a strong component of sensitivity analysis. In this way, uncertainties associated with experimental data points and postulated costs can be better taken into account in the comparisons.

\subsubsection{Impact of Time}

The passage of time will introduce important changes in technology, pollution levels, the perceived need for action, the level of agreed-upon standards, and related costs.

Perhaps the simplest conceptual path to reduced emissions is increased efficiency. Under a recent Cooperative Research and Development Agreement, the DOE and the three major U.S. automobile companies are seeking to triple fuel efficiency in about 10 years. Of course, more efficient vehicles can be produced today, but are not being sought by purchasers. Also, the beneficial impacts of efficiency can be undone by offsetting increases in vehicle miles traveled. Further, the main possibility for reducing emissions such as greenhouse gases appears to be more in changes in fuel sources (e.g., electric vehicles drawing upon renewable power sources, or ethanol vehicles drawing upon biofuels feedstocks). Still other changes, both technological and social, could be derived from greater use of mass transit and/or increased levels of telecommunication in which personal travel is replaced by electronic linkages.

While technology development may help to make certain activities possible, the establishment of standards may be necessary to ensure that they actually occur. For this reason, California and other states which are following California's lead, are mandating that annual sales containing an 
increasing number of low, ultra-low, and zero emission vehicles. The Clean Air Act of 1990 mandates the use of reformulated (oxygenated) gasoline to reduce the emission levels of unburned hydrocarbons. Starting in November of 1992, minimum oxygen levels are mandated for gasoline sold in the worst winter months in the 39 carbon monoxide non-attainment cities. By 1995, RFG will be available for all ozone and CO non-attainment areas, covering about half the U.S. gasoline supply. Reformulation will also address reductions in volatility and in toxic emissions.

As standards are tightened, and mitigation steps invoked, the estimated costs of future avoidance are likely to increase. Typically this has been so because low-cost solutions become exhausted, the volume of utilization increases, offsetting gains in reductions, experience shows that actual costs have been underestimated, and standards may be proposed for further tightening.

Because standards, technology, efficiency, avoidance costs and other key variables can change over time, the LCC Model provides for the values in the Model to be overwritten by the user, thus both maintaining an up-to-date view of the current state of comparative analyses, and also providing for ease of sensitivity analysis.

For example, cumulative emissions will be impacted by the actual penetration rate of new vehicles and alternative fuels into the present fleet. The emissions associated with electric vehicles will depend what portion of the installed electric power base is actually used for recharging, and the fuels and technology applied for that generation step.

It will be desirable to explore the significance of these and other input variables with respect to the ability of LCC Model results to contribute to a review of policy options. 


\subsection{EXPANSION OF THE LCC MODEL FOR HYDROGEN PROTON EXCHANGE MEMBRANE FUEL CELL/BATTERY POWERED VEHICLES}

\subsection{Characteristics of the LCC Model for Hydrogen PEMFC/Battery Vehicles}

Expansion of the Model for analysis of vehicles powered by hydrogen fueled Proton Exchange Membrane (PEM) fuel cells with onboard hydrogen storage was accomplished due to modularity of the Model architecture. The complete power system consists of three major components: the fuel cell stack and auxiliary systems (air compressor, cooling system, and water management system), the fuel storage and delivery system, and the peak-power system. Specific model modification with regard to the fuel cell and fuel storage systems are discussed in the following sections. Peak-power for the vehicles under consideration is provided by batteries. Since the power density of hydrogen fueled PEMFC system is higher than the methanol fueled PEMFC system, design fuel cell power requirements are similar for both fuel types even though the hydrogen storage system is adds weight and bulk. Likewise, the design power requirements for the peak-power battery is also similar. Therefore, no Model modification to the peak-power battery module was required.

Model modifications were required to account for the significant improvement in emissions performance characteristics. The Model currently considers emissions associated with refueling and onboard combustion, not the full fuel cycle. Model modifications were required to various cost and performance parameters, most significantly fuel and maintenance and repair costs. The Model modifications are all predicated on technology availability by the year 2000 .

\subsubsection{Hydrogen PEMFC Characteristics}

Table 3.1 shows the PEM fuel cell characteristics added to the fuel cell options in the Model. The selections were based on recent work by Delucchi (Reference 6) that suggests hydrogen PEMFC operating to 3.4 atmospheres provides an optimal mix of system complexity and energy density. These characteristics are supported by numerous research results as being commercially available at the quoted relative price in the year 2000. Delucchi cites one researcher who believes that it should be possible to achieve a specific power of $1,300 \mathrm{~W} / \mathrm{kg}$ and a power density of 1,200 W/liter for a PEM fuel cell stack operating at atmospheric pressure. Salvage value is 
assumed to be $\$ 960$ per unit in order to be consistent with other fuel cells in the Model. These parameters integrate fully with the JPL-based design relationships in the Model (Reference 1).

Table 3.1: Hydrogen PEM Fuel Cell Characteristics @ 3.4 Atmospheres

\begin{tabular}{|c|c|c|c|c|c|c|}
\hline \multicolumn{2}{|c|}{$\begin{array}{l}\text { Specific Power } \\
(W / k g)\end{array}$} & \multicolumn{2}{|c|}{$\begin{array}{c}\text { Power Density } \\
\text { (W/liter) }\end{array}$} & \multirow{2}{*}{$\begin{array}{c}\text { Efficiency } \\
(\%)\end{array}$} & \multirow{2}{*}{$\begin{array}{c}\text { Capital } \\
\text { Cost } \\
\text { (1990\$) }\end{array}$} & \multirow{2}{*}{$\begin{array}{c}\text { Salvage } \\
\text { Value } \\
\text { (1990\$) }\end{array}$} \\
\hline Continuous & Peak & Continuous & Peak & & & \\
\hline 230 & 465 & 340 & 688 & 53 & $\$ 180$ & $\$ 960$ \\
\hline
\end{tabular}

\subsubsection{Onboard Hydrogen Storage Characteristics}

Compressed gas storage is chosen as the onboard hydrogen fuel storage method because of its simplicity, reasonable weight and space requirements, is commercially available at reasonable cost relative to other hydrogen storage methods, is safe, and can be refueled relatively quickly. Table 3.2 lists the storage system characteristics for a 400-kilometer (km) range car. System design is based upon recent work by Delucchi (Reference 6). Carbon wrapped aluminum lined vessels with pressure at 8,000 psi yields a sufficient storage capacity for a $400-\mathrm{km}$ range with reasonably compact space requirements. The boundaries of ideal gas behavior and exponential increases in vessels weight, bulk and cost relative to incremental reductions in storage volume indicate storage pressure to 8,000 psi may be a good balance of capacity, bulkiness and cost. Delucchi observes that vehicle designers could take advantage of the simplicity, reliability, long life, and strength of high pressure storage tanks by permanently integrating them into the vehicle frame structure. This would reduce the obtrusive space requirements of the system.

Table 3.2: Hydrogen Storage System Characteristics

\begin{tabular}{||l|r|}
\hline \hline Hydrogen fuel energy needed, full tank & 0.33 million Btu \\
\hline Weight of hydrogen fuel & $2.47 \mathrm{~kg}$ \\
\hline Inner capacity of storage tank & 81.52 liters \\
\hline $\begin{array}{l}\text { Weight of storage system, including valves, } \\
\text { regulators, flowlines, etc. }\end{array}$ & $66.82 \mathrm{~kg}$ \\
\hline Retail price of storage system & $\$ 2,692(1990 \$)$ \\
\hline
\end{tabular}

Engineering Systems Management, Inc. 
These characteristics are based on consultation with industry consultants to estimate the size, weight, and OEM cost of hydrogen storage vessels. Relationships developed by Delucchi were added to the Model (Reference 6).

\subsubsection{Environmental Emissions Characteristics}

It is noteworthy to mention that PEM fuel cells supplied with hydrogen stored onboard produce none of the emissions components analyzed in the current Model, namely $\mathrm{CO}, \mathrm{NO}_{x}, \mathrm{HC}$, GHGs, $\mathrm{SO}_{2}, \mathrm{PM}$ and toxics. The Model only considers emissions resulting from vehicle refueling and onboard combustion/conversion. The Model was modified to generate zero emissions for hydrogen fueled PEMFCs.

\subsubsection{Hydrogen Fuel Characteristics}

Hydrogen gas was added to the Model as a fuel option for PEM fuel cells. Table 3.3 shows the hydrogen fuel characteristics entered into the Model. The commercialized cost used is estimated by Delucchi based on the gasoline-equivalent price per btu delivered to the vehicle (Reference 9). These prices include average federal and state taxes of $\$ 0.31$ per gallon-equivalent. This gasoline-equivalent cost does not account for the efficiency with which the vehicle uses that energy. The large advantage in energy efficiency for hydrogen fueled PEM FCEVs will likely provide upward pressure on market prices, all other things equal.

Table 3.3: Hydrogen Fuel Characteristics

\begin{tabular}{||l|r||}
\hline \hline Volumetric density & $0.023 \mathrm{~kg} /$ liter \\
\hline Energy density & 3,056 Btu/liter \\
\hline Estimated commercialized retail cost & $\$ 0.78$ per liter \\
& $\$ 2.97$ per gallon \\
& $\$ 23.74$ per million Btu \\
\hline
\end{tabular}




\subsubsection{Maintenance and Repair Characteristics}

The maintenance and repair (M\&R) costs of electric vehicles (EVs) are expected to be significantly lower than ICE vehicles after some level of significant commercialization. This is due to the relative simplicity and reliability of electric drivetrains. M\&R costs generally include scheduled and unscheduled maintenance to the vehicle chassis, suspension and drivetrain, but excludes tires, brakes and fluids maintenance. The literature is replete with cost analyses, some based on the actual road experience of hundreds of vehicles, concluding M\&R costs for Evs 35 to 66 percent lower than comparable ICE vehicles, depending upon assumption of individual analyses. Most of the available evidence and analyses pertain to BPEVs; not FCEVs.

FCEVs will have two additional major components: a fuel cell, and a fuel storage/processing system, which consists of either a hydrogen storage system or a methanol storage tank and reformer. FCEVs also have a smaller battery system which reduces overall M\&R costs even though most analyses assume batteries are relatively maintenance-free. Battery replacement costs, if battery life is less than vehicle life, is a separate operating and maintenance cost item in the Model. While M\&R costs for FCEVs will be related to the complexity of the system, the hydrogen PEMFC with compressed gas fuel storage system is a relatively simple, reliable power system.

The most recent work by Delucchi (1993) conservatively estimated annual M\&R costs for a 400$\mathrm{km}$ range hydrogen fueled PEM FCEV of $\$ 435$ (1990\$) assuming a maintenance-free battery and annual PEM M\&R costs of $\$ 40$. This cost is 16 percent less than a comparable gasoline ICE vehicle. For this analysis, a $16 \%$ reduction in baseline gasoline ICE vehicle M\&R costs was assumed. To affect this change in the Model which calculates M\&R costs based on a JPL algorithm (Reference 1), a maintenance factor of 0.0037 was used for cars. For vans, maintenance costs are assumed to be proportionally higher based on the rated power. A maintenance factor of 0.0052 was used for vans. 


\subsection{Life Cycle Cost Analysis}

LCC analyses of hydrogen PEMFC/Battery powered vehicles was run for two cases: cars and vans. These case analyses were run and are reported here for the purpose of demonstrating the functionality of the Model's expanded capability to analyze hydrogen PEMFC/battery powered vehicles, not to perform a comparative analysis. The results are validated by comparison to the case analyses performed under the prior work (Reference 1 ).

\subsubsection{Cars}

Table 3.4 presents selected characteristics of the hydrogen PEMFC/battery powered car in the analysis. The vehicle type is a five-passenger mid-size automobile. The analysis base year is 2000. Vehicle life is set at 10 years and 160,000 kilometers life cycle distance traveled. Table 3.5 presents the results of the LCC analysis for the same car.

These results compare favorable with Delucchi who has done the most comprehensive work in the LCC analysis of hydrogen FCEVs. Delucchi's most recent modeling analysis of a comparable $1,238 \mathrm{~kg}$, five/six-passenger, $400-\mathrm{km}$ range vehicle with a total life of $256,800 \mathrm{~km}$,

Table 3.4: Characteristics of a Hydrogen PEMFC/Battery Powered Car

\begin{tabular}{||l|c|}
\hline Vehicle range & $400 \mathrm{~km}$ \\
\hline Hydrogen storage system & $\begin{array}{c}\text { Carbon wrapped aluminum tank } \\
@ 8,000 \mathrm{psi} \text { full charge }\end{array}$ \\
\hline Fuel cell full power rating & $23 \mathrm{Kw}$ \\
\hline Fuel cell efficiency rating & $53 \%$ \\
\hline Fuel cell weight & $49 \mathrm{~kg}$ \\
\hline Battery type & $13 \mathrm{~kW}$ \\
\hline Battery power rating & $64 \mathrm{~kg}$ \\
\hline Battery weight & $1,472 \mathrm{~kg}$ \\
\hline Vehicle curb weight & 0.32 \\
\hline Coefficient of drag & $31.67 \mathrm{~km} /$ liter \\
\hline Fuel economy & $74.49 \mathrm{mpg}$-equivalent \\
\hline
\end{tabular}


Table 3.5: LCC Results for a Hydrogen PEMFC/Battery Powered Car

\begin{tabular}{||l|rc||}
\hline \multicolumn{1}{|c|}{ Cost Element } & Life Cycle Cost & Cost per $\mathbf{~ k m}$ \\
\hline \hline Total vehicle capital cost & $\$ 22,671.03$ & $\$ 0.1417$ \\
\hline Hydrogen storage system capital cost & $\$ 2,692.00$ & $\$ 0.0168$ \\
\hline Fuel cell capital cost & $\$ 5,965.41$ & $\$ 0.0373$ \\
\hline Battery capital cost & $\$ 2,088.83$ & $\$ 0.0131$ \\
\hline Total operation cost & $\$ 18,223.88$ & $\$ 0.1139$ \\
\hline Total fuel cost & $\$ 3,433.29$ & $\$ 0.0215$ \\
\hline Total repair \& maintenance cost & $\$ 3,767.76$ & $\$ 0.0235$ \\
\hline Replacement battery cost & $\$ 1,809.10$ & $\$ 0.0113$ \\
\hline Environmental cost & $\$ 0.00$ & $\$ 0.0000$ \\
\hline Total Life Cycle Cost & $\$ 40,219.68$ & $\$ 0.2514$ \\
\hline
\end{tabular}

resulted in an initial capital cost of $\$ 25,446$ (a variance of +12 percent) and an LCC cost of $\$ 0.2133$ per kilometer (a variance of $-15 \%$ ) (Reference 6). The variance in total LCC cost per kilometer would converge further if the life of this analysis vehicle were extended to approximate Delucchi's vehicle life due to the spreading of capital costs over more kilometers.

\subsubsection{Vans}

Table 3.6 presents selected characteristics of the hydrogen PEMFC/battery powered van in the analysis. The vehicle type is a six-passenger plus mid-size urban van. The analysis base year is 2000 . Vehicle life is set at 10 years and 160,000 kilometers life cycle distance traveled. Table 3.7 presents the results of the LCC analysis for that same van. 
Table 3.6: Characteristics of a Hydrogen PEMFC/Battery Powered Van

\begin{tabular}{|l|c|}
\hline Vehicle range & $400 \mathrm{~km}$ \\
\hline Hydrogen storage system & $\begin{array}{c}\text { Carbon wrapped aluminum tank } \\
@ 8,000 \mathrm{psi} \text { full charge }\end{array}$ \\
\hline Fuel cell full power rating & $31 \mathrm{~kW}$ \\
\hline Fuel cell efficiency rating & $53 \%$ \\
\hline Fuel cell weight & $66 \mathrm{~kg}$ \\
\hline Battery type & $17 \mathrm{~kW}$ \\
\hline Battery power rating & $86 \mathrm{~kg}$ \\
\hline Battery weight & $1,816 \mathrm{~kg}$ \\
\hline Vehicle curb weight & 0.47 \\
\hline Coefficient of drag & $22.17 \mathrm{~km} /$ liter \\
\hline Fuel economy & $52.14 \mathrm{mpg}$-equivalent \\
\hline
\end{tabular}

Table 3.7: LCC Results for a Hydrogen PEMFC/Battery-Powered Van

\begin{tabular}{||l|rc|}
\hline \multicolumn{1}{|c|}{ Cost Element } & LCC Cost & Cost per $\mathbf{~ k m}$ \\
\hline \hline Total vehicle capital cost & $\$ 34,307.60$ & $\$ 0.2144$ \\
\hline Hydrogen storage system capital cost & $\$ 3,845.71$ & $\$ 0.0240$ \\
\hline Fuel cell capital cost & $\$ 8,002.15$ & $\$ 0.0500$ \\
\hline Battery capital cost & $\$ 7,625.83$ & $\$ 0.0477$ \\
\hline Total operation cost & $\$ 20,944.40$ & $\$ 0.1309$ \\
\hline Fuel cost & $\$ 4,904.71$ & $\$ 0.0307$ \\
Repair \& maintenance cost & $\$ 4,607.75$ & $\$ 0.0288$ \\
\hline Battery replacement cost & $\$ 2,311.61$ & $\$ 0.0144$ \\
\hline Environmental cost & $\$ 0.00$ & $\$ 0.0000$ \\
\hline Total Life Cycle Cost & $\$ 54,439.26$ & $\$ 0.3402$ \\
\hline
\end{tabular}

No directly comparable work has been identified to provide validation. However, relative to the car case, the results seem reasonable given the vehicle size and configuration differentials. 


\subsection{NEW OPERATIONAL FEATURES OF THE UPGRADED LIFE CYCLE COST MODEL EXPANDED FUEL CYCLE EMISSION DATA AND VALUE/COST ASSIGNMENTS}

Various modifications made to the Model as previously described in Sections 2 and 3 include the following:

- Transition to Quattro Pro for Windows ${ }^{\text {in }}$ in order to achieve greater flexibility in design and use;

- Complete revalidation and adjustment as required of all equations and data previously incorporated in the Model;

- Expansion and revision of included data on fuel cycle emissions;

- Expansion and revision of included data on the economic value/cost of such emissions;

- Addition of a hydrogen-fueled PEMFC/battery-powered vehicle to the set of vehicles included for analysis; and

- Addition of user-friendly dialog boxes and as a speed bar interface to facilitate case selection, data input, and Model operation.

\subsection{New Operational Features of the Life Cycle Cost Model}

As a first step in enhancing functionality, the program was imported from a collection of individual Excel ${ }^{\oplus}$ spreadsheets into Quattro Pro for Windows ${ }^{\circledast}$. The Quattro Pro ${ }^{\circledast}$ format and utilities permit the user to access all of the data on the individual notebook pages more rapidly and conveniently, provide superior audit trail capabilities for error checking, and facilitate the installation of a user-friendly set of speed bar buttons and dialog boxes for Model operation.

Two files are necessary. The main spreadsheet program is labeled LIFECOST.WB1, and its associated speedbar file is labeled LIFECOST.BAR. It is only necessary to load the spreadsheet. A macro in the spreadsheet automatically loads the speedbar, as long as the latter is in the same directory as the spreadsheet file.

The transfer in file form was achieved by direct importing of the twelve original individual Excel $^{\circledast}$ files in to the Quattro Pro ${ }^{\circledast}$ notebook pages. This ensured that no errors in equations or 
references were introduced in the transfer process. Twelve of the pages of the Quattro Pro ${ }^{\circledR}$ notebook are directly equivalent to the prior set of Excel ${ }^{\oplus}$ files. An Introduction Screen has been added to provide instructions on how to use the model. In addition, two new notebook pages were added: one to describe the hydrogen-fueled PEM fuel cell (discussed below) and the other to contain the menus and macros for the user-friendly features.

The resulting LIFECOST notebook pages and their relationship to the files of the original Model are shown as follows:

\begin{tabular}{||l|l||}
\hline Notebook Page (Version 4) & \multicolumn{1}{|c|}{ Source } \\
\hline \hline INTRO & (NEW) \\
\hline BASIC VEHICLE & BASIC VEHICLE \\
\hline BATTERY & BATTERY \\
\hline CAPITAL & CAPITAL COST \\
\hline COSTOUT & LIFE CYCLE COST \\
\hline ENERGY & ENERGY \\
\hline ENVIRON & ENVIRONMENTAL COST \\
\hline FINANCE & FINANCIAL \\
\hline FUELCELL & FUEL CELL \\
\hline H2PEM & (NEW) \\
\hline INPUT & INPUT \\
\hline OPCOST & OPERATING COST \\
\hline POWERSYS & POWER SYSTEM \\
\hline SALVAGE & SALVAGE \\
\hline MENUS & (NEW) \\
\hline
\end{tabular}

Following importation into the new format, the audit trail and error checking features of the Quattro Pro ${ }^{\circledast}$ spreadsheet program were used to trace and verify the accuracy of the equations. Original data sources were reviewed, and the correctness of the embedded data sets were also reverified. In the course of this work, some errors in equations were in fact discovered and corrected. These were principally associated with techniques for calculating present value of cash flow streams. The numerical significance of such errors was small and they did not, in any case, impact relative rankings of alternative vehicles and fuels. The current values of the Embedded Data Sets are shown in Appendix $\mathbf{C}$. 
Version 4.0 of the Model, as included here, has now undergone a complete review and is believed to accurately reflect all of the data sources and relationships reflected in the literature which served as a basis for its construction.

Another problem area which existed in the initial version of the Model was the reliance upon user input being obtained through the entry of information directly into cells of the spreadsheet. Not only could incorrect entries be made inadvertently by the user (or even correct information into incorrect cells), but it was also possible to make sets of inputs that were logically incompatible in terms of vehicle/system/fuel combinations.

Accordingly, the Model has now been revised to receive all normal input through sets of dialog boxes which are logically related to each other, rely on selection of options from pre-established Pick Lists, and which exclude any possibility of incompatible option elements. When the dialog box closes (after selection of elements therefrom by the user) the selected data is introduced into the appropriate spreadsheet cell by internal program commands which do not depend on the user to be performed correctly. The spreadsheet then recalculates, and the results are presented for review, both graphically and in tabular form.

Advanced users are still free to move around the spreadsheet manually to examine components of the calculation in more detail, or to alter other factors used in the calculations (equations, embedded data sets, inputs not normally expected to be modified between cases, etc.). However, the normal and routine use of the program can now be accomplished entirely through dialog boxes and the speed bar buttons which call them up as well as perform other data management functions.

The speedbar and dialog boxes can be edited from the "graph page" of the Quattro Pro ${ }^{\circledast}$ system as described in the program manual. The macros and data repositories used by the speedbar and dialog boxes appear on the MENUS notebook page. Additional equations, which translate dialog box outputs into the form needed for model input and processing, appear at the bottom (cells B70 through E90) of the INPUT page. 
All information on the various pages of the Model has been color coded. Yellow shading is used to identify non-numeric inputs (e.g., text cells). Blue shading is used to identify numeric inputs which advanced users may change (e.g, embedded data sets). Green shading is used for cells which contain equations. Purple shading is used for a few cells which contain "hard-wired" data inputs as part of the equation. Changing this data requires the user to edit the equation in the cell. All such "hidden data" input points will be extracted from equations and placed into identified blue cells for the final version of the Model to be delivered with the final report of task activity.

In addition to the validation review and functionality improvements summarized above, the Model capability has been expanded in terms of new quantitative data on emissions, the economic costs of emissions (and oil imports), and the inclusion of a new alternative system, the hydrogen fueled PEMFC/battery powered vehicle.

\subsection{Expanded Fuel Cycle Emissions Data and Value/Cost Assignments}

The emissions incorporated into the initial version of the LCC Model, CO, $\mathrm{NO}_{\mathrm{x}}$, and $\mathrm{HC}$ are augmented in Version 4.0 of the Model with $\mathrm{GHGs}, \mathrm{SO}_{2}, \mathrm{PM}$, and Toxics. This model expansion was accomplished under Task 1 and is discussed in detail in the Task 1 Interim Report entitled "Expanded Environmental Analysis For the Alternative Transportation Systems Life Cycle Cost Model." The emissions incorporated into the initial version of the Model were selected for their importance as smog precursors $\left(\mathrm{NO}_{\mathrm{x}}\right.$ and $\mathrm{HC}$ ) and deleterious health effects $(\mathrm{CO})$. A survey of the extensive literature on transportation systems cross-technology comparisons indicated that a more complete set of emission characterization to assess comparative environmental impacts would be appropriate. Based on the analysis of the available data, the following decisions were made regarding emissions to be incorporated in the LCC Model.

- Greenhouse Gases emissions are valued at $\$ 60$ per ton (or about $\$ 16$ per ton $\mathrm{CO}_{2}$ ) in Version 4 of the Model.

- Nitrogen oxide, carbon monoxide and sulfur oxides. These emissions are valued at $\$ 5,000$ per ton for $\mathrm{NO}_{\mathrm{x}} ; \$ 850$ per ton for $\mathrm{CO}$; and $\$ 60$ per ton of $\mathrm{SO}_{2}$.

- Particulate Matter is valued at $\$ 4,500$ per ton. 
- Toxics are valued at $\$ 2,000$ per ton and hydrocarbons are valued at $\$ 10,000$ per ton in Version 4 of the Model.

- A calculated national security premium of $\$ 0.275$ per gallon of gasoline is used in the Model.

\subsection{User's Manual}

The program calculates Total Life Cycle Costs for cars and vans, including the costs of capital, operations, and the economic value of emissions. All results are presented on a present value basis for a user-selected discount rate.

The program is operated by a speedbar presenting the necessary commands. Advanced users of course enter the spreadsheet to modify default values and equations directly if desired.

The speedbar button CHOOSE VEHICLE brings up a dialog box for user input. Separate Pick Lists are provided in the box to select Vehicle Type (Internal Combustion Engine - ICE, Fuel Cell Vehicle - FCV or Electric Vehicle - EV), Body Type (Car or Van), and Transmission Type (Automatic or Manual). This box must be closed using the OK button in order to bring up a second related dialog box. This second box requests additional user selections which depend upon the original Vehicle Type selected in the first dialog box.

For ICE Vehicles, the follow-on choices allow the selection of one or eight possible fuels. For FCVs the follow-on choices allow the selection of the PEM type cell fueled with either Methanol 100 (produced from renewable biomass) or Hydrogen (produced from nuclear or solar electricity). System aspects of the associated battery system and electric drive train are also selected here. For EVs, the follow-on choices allow the selection of the battery type and technology.

In all the dialog boxes, selections are made by choosing one item from each Pick List by leftclicking with a mouse. When the second dialog box in the set is closed by left-clicking on the OK Button, the spreadsheet calculates, and displays a graphical and tabular presentation of the results. 
The EMISSION COSTS button allows the selection of economic parameters to describe the avoided costs of the transportation fuel cycle emissions (For Greenhouse Gases only, the emissions include those incurred in the manufacturing step as well as the transportation fuel cycle).

The OTHER INPUTS button allows other performance and cost inputs to be selected. These items would typically be modified less frequently, or for explicit sensitivity analysis. Key financial inputs (base year of the analysis, discount and inflation rates) appear in this dialog box.

The RESTORE DEFAULTS button resets all entries from the EMISSION COSTS and OTHER INPUTS dialog boxes to their default values. These preset values appear in cells K11 through K38 of the Menus notebook page of the spreadsheet, and can be changed by the user overwriting data in those cells.

The SAVE button simply saves the program to its normal directory location under the existing file name. If a separately named version is to be saved, the user must employ the Save As. . command from the spreadsheet's main File menu. 


\subsection{REFERENCE CASE ANALYSIS RESULTS}

The following fourteen cases were analyzed for this work:

$\begin{array}{ll}\text { Case 1A } & \text { Reference Car - Conventional Gasoline/Automatic Transmission } \\ \text { Case 1B } & \text { Reference Car - Conventional Gasoline/Manual Transmission } \\ \text { Case 2A } & \text { Reference Van - Conventional Gasoline/Automatic Transmission } \\ \text { Case 2B } & \text { Reference Van - Conventional Gasoline/Manual Transmission } \\ \text { Case 3A } & \text { Reference Car - Conventional Diesel/Automatic Transmission } \\ \text { Case 3B } & \text { Reference Car - Methanol M-100/Automatic Transmission } \\ \text { Case 3C } & \text { Reference Car - Ethanol E-100/Automatic Transmission } \\ \text { Case 3D } & \text { Reference Car - Compressed Natural Gas/Automatic Transmission } \\ \text { Case 3E } & \text { Reference Car - Reformulated Gasoline/Automatic Transmission } \\ \text { Case 3F } & \text { Reference Car - Reformulated Diesel/Automatic Transmission } \\ \text { Case 3G } & \text { Reference Car - Methanol Blend M-85/Automatic Transmission } \\ \text { Case 4A } & \text { Reference Electric Car - High Technology Lead-Acid Battery/DC Brushless } \\ & \text { Motor/Automatic Transmission } \\ \text { Case 5A } & \text { Reference Fuel Cell/Battery Car - Methanol M-100/PEMFC/Medium } \\ \text { Case 5B } & \text { Referformance Generic Battery/DC Brushless Motor/Automatic Transmission } \\ & \text { Generic Battery/DC Brushless Motor/Automatic Transmission }\end{array}$

The case run LCC Model results are presented in detail in Appendix D.

\subsection{Reference Car/Van Cases with Conventional Fuel}

The details of a Total Life Cycle Cost of $\$ 35,378$ are shown in Table 5.1.1 for the Reference Car. This case is based on:

- Spreadsheet default values;

- Conventional ICE Engine;

- Car Body Type, and

- Automatic Transmission; using

- Conventional Gasoline.

The user can obtain this case result and associated details by selecting the RESTORE DEFAULTS bar on the spreadsheet speedbar, selecting the CHOOSE VEHICLE bar, and then selecting the appropriate descriptions on the two dialogue boxes which are offered for this purpose. 
Table 5.1.2 shows the results for this same Reference Car, and compares them to the same total cost elements for a car with manual transmission, and vans with both automatic and manual transmissions. All of the cases in this table are based on spreadsheet defaults, a conventional ICE engine, and conventional gasoline fuel. Note that in this and subsequent tables, salvage costs are included in capital cost totals unless indicated otherwise.

Table 5.1.1: Total Life Cycle Costs - Reference Car

\begin{tabular}{|c|c|c|c|}
\hline \multicolumn{2}{|l|}{ Capital Cost } & \multicolumn{2}{|c|}{ Salvage Value } \\
\hline Basic Vehicle & $\$ 11,187$ & Battery & \\
\hline Battery & $\$ 62$ & Fuel Cell & - \\
\hline Motor & \multirow[b]{2}{*}{$\$ 1,492$} & Basic Vehicle & $\$(100)$ \\
\hline Engine & & Total Salvage & $\$(100)$ \\
\hline Controller & \multirow{3}{*}{$\$ 188$} & $\begin{array}{l}\text { Total Capital, Operating, } \\
\text { and Salvage Costs }\end{array}$ & $\$ \mathbf{3 3}, \mathbf{1 8 3}$ \\
\hline Transmission & & \multicolumn{2}{|c|}{ Emissions Cost } \\
\hline Fuel Cell & & $\mathrm{HC}$ & $\$ 724$ \\
\hline Fuel Tank & $\$ 202$ & $\mathrm{CO}$ & $\$ 531$ \\
\hline Accessories & $\$ 2,500$ & $\mathrm{NO}_{\mathrm{x}}$ & $\$ 230$ \\
\hline Total Vehicle Capital Cost & $\$ 15,630$ & Particulates & $\$ 7$ \\
\hline \multicolumn{2}{|l|}{ Operating Cost } & $\mathrm{SO}_{2}$ & $\$ 3$ \\
\hline Energy Cost & & Aldehydes & $\$ 1$ \\
\hline Electricity & - & BTX & $\$ 15$ \\
\hline Fuel & $\$ 5,872$ & $\mathrm{CO}_{2}$ Equivalent & $\$ 684$ \\
\hline Repairs/Maintenance & $\$ 5,159$ & Total Emission & $\$ 2,195$ \\
\hline \multicolumn{4}{|l|}{ Replacement } \\
\hline Tires & $\$ 546$ & & \\
\hline Battery & - & & \\
\hline Fuel Cell & - & & \\
\hline Insurance & $\$ 4,785$ & & \\
\hline Garage/Park/Tolls & $\$ 663$ & & \\
\hline Title/Register/License & $\$ 627$ & & \\
\hline Total Operating Costs & $\$ 17,653$ & Total Life Cycle Cost & $\$ 35,378$ \\
\hline
\end{tabular}


Table 5.1.2: Total Life Cycle Costs Reference Cases - Cars and Vans Conventional Gasoline Fuel/Conventional ICE Engine

\begin{tabular}{||l|r|r||}
\hline \multicolumn{3}{|c|}{ Automatic Transmission } \\
\hline & \multicolumn{1}{|c|}{ Car } & \multicolumn{1}{c|}{ Van } \\
\hline \hline Capital & $\$ 15,530$ & $\$ 18,840$ \\
\hline Operating & $\$ 17,653$ & $\$ 20,140$ \\
\hline Emissions & $\$ 2,195$ & $\$ 2,633$ \\
\hline Total & $\$ 35,378$ & $\$ 41,613$ \\
\hline \multicolumn{3}{|c|}{ Manual Transmission } \\
\hline \multicolumn{2}{|c|}{ Car } & Van \\
\hline Capital & $\$ 15,612$ & $\$ 18,951$ \\
\hline Operating & $\$ 17,655$ & $\$ 20,143$ \\
\hline Emissions & $\$ 2,195$ & $\$ 2,633$ \\
\hline Total & $\$ 35,462$ & $\$ 41,728$ \\
\hline
\end{tabular}

The small dollar difference between automatic and manual transmission shows up primarily in the basic vehicle capital costs as a constant amount. Accordingly, all subsequent case discussions will be on automatic transmission vehicles only.

The differences between the results shown in Table 5.1.2 for the car and the van (both with automatic transmission) are associated with the following:

- The more expensive capital cost for the van arises primarily from the basic vehicle cost (i.e., weight) with smaller companion increases in the costs of battery, engine and transmission;

- The more expensive operating cost of the van arises primarily from the Repairs/Maintenance category, with smaller companion increases in the costs of tire replacement, and title, registration and licensing costs; and

- The more expensive emissions cost of the van arises in somewhat uniform increases in the values ascribed to the four major emission sources: $\mathrm{HC}, \mathrm{CO}, \mathrm{NO}_{\mathrm{x}}$ and $\mathrm{CO}_{2}$ equivalent; this appears to be a direct consequence of assumed lower efficiency in fuel utilization. 
Given the standard character of the dollar value of the life cycle deviations from the Reference Car case (for vans, as well as transmissions), subsequent results and sensitivity studies reported here focus on the Reference Car.

\subsection{Reference Car Case with Alternative Fuels}

Table 5.2 compares results for the Reference Car utilizing different fuels. The capital costs are nearly the same in all cases (since changes in fuel tank costs are small relative to the cost of the total vehicle). Accordingly, the cases primarily reflect trade-offs in the cost of fuels (in the operations category) relative to the value of the emissions. Since reformulated diesel is assumed to be manufactured from biofuels, it avoids an oil import premium as part of the fuel cost incurred by conventional diesel and by both conventional and reformulated gasoline. The results for total life cycle costs fall within a range of less than \pm 10 percent of the central Reference Car case. Accordingly, apparent differences should be viewed with considerable caution. Some suggestive areas for further exploration appear to be as follows:

- Conventional natural gas vehicles look interesting here because they display both operating and emission cost reductions; so do the diesel cases, albeit on a much more modest scale.

- E-100 biomass cuts emission costs by 60 percent; however, reductions in fuel manufacturing costs would appear to be necessary to make its use attractive;

- Methanol appears to achieve only a modest benefit in emission reduction overall, which must be offset against a significant increase in fuel costs; and

- Reformulated gasoline, with the assumptions used here, trades higher costs of manufacture for reduced emission without achieving any clear overall net benefit. 
Table 5.2: Total Life Cycle Costs Reference Car with Various Fuels

\begin{tabular}{|l|r|r|r|r||}
\hline \multirow{2}{*}{\multicolumn{1}{|c|}{ Fuel }} & \multicolumn{4}{|c|}{$\leftarrow$ Costs $\rightarrow$} \\
\cline { 2 - 5 } & \multicolumn{1}{|c|}{ Capital } & \multicolumn{1}{c|}{ Operating } & \multicolumn{1}{c|}{ Emission } & \multicolumn{1}{c|}{ Total } \\
\hline \hline Conventional Gasoline & $\$ 15,530$ & $\$ 17,653$ & $\$ 2,195$ & $\$ 35,378$ \\
\hline Conventional Diesel & $\$ 15,605$ & $\$ 17,098$ & $\$ 1,922$ & $\$ 34,624$ \\
\hline Methanol M-100 & $\$ 15,601$ & $\$ 19,631$ & $\$ 1,641$ & $\$ 36,873$ \\
\hline Ethanol E-100 & $\$ 15,500$ & $\$ 21,523$ & $\$ 866$ & $\$ 37,889$ \\
\hline Compressed Natural Gas & $\$ 15,911$ & $\$ 17,053$ & $\$ 1,116$ & $\$ 34,080$ \\
\hline Reformulated Gasoline & $\$ 15,534$ & $\$ 18,242$ & $\$ 2,084$ & $\$ 35,859$ \\
\hline Reformulated Diesel & $\$ 15,605$ & $\$ 16,422$ & $\$ 1,662$ & $\$ 33,689$ \\
\hline Methanol Blend M-85 & $\$ 15,606$ & $\$ 19,112$ & $\$ 1,725$ & $\$ 36,443$ \\
\hline \hline
\end{tabular}

On the spreadsheet, electric vehicles can be compared using a number of variables. These include:

- Generic battery type (low, medium, or high performance) or one of ten specific battery technologies (from Aluminum-Air to Zinc-Chloride);

- An overall indication of battery technology of either high or low; and

- Three different types of motor controllers, namely alternating current, direct current brushless, and direct current brush.

\subsection{Reference Electric Car Case}

Since the primary purpose of the current work is to examine fuel cell vehicles relative to conventional vehicles, only a single electric vehicle case is reported here; however, it is quite representative of the other electric vehicle combinations on the spreadsheet. Table 5.3 shows the complete life cycle cost results for Reference Electric Car Case with automatic transmission, using a high technology lead-acid battery with a direct current brushless motor. Emission costs include those incurred from the average U.S. electric generation mix. 
Table 5.3: Total Life Cycle Costs Reference Electric Car Case

\begin{tabular}{|lr|}
\hline Capital Cost & \\
\hline \hline Basic Vehicle & $\$ 16,000$ \\
Other Components & $\$ 2,863$ \\
Accessories & $\$ 2,500$ \\
Salvage & $\$(194)$ \\
\hline Total Capital & $\$ 21,169$ \\
\hline \hline Operating Cost & \\
\hline \hline Electricity & $\$ 2,771$ \\
Repairs/Maintenance & $\$ 5,066$ \\
Replacement & $\$ 1,971$ \\
Insurance & $\$ 4,785$ \\
Garage/Park/Tolls & $\$ 663$ \\
Title/Register/License & $\$ 795$ \\
\hline Total Operating Cost & $\$ 16,051$ \\
\hline Emissions Costs & $\$ 33$ \\
\hline \hline HC & $\$ 99$ \\
CO & - \\
NO & $\$ 11$ \\
Particulates & - \\
SO & $\$ 642$ \\
Aldehydes/BTX & $\$ 790$ \\
CO ${ }_{2}$ Equivalent & $\$ 38,010$ \\
\hline Total Emissions & \\
\hline Total Life Cycle Cost & \\
\hline & \\
\hline
\end{tabular}

The comparison of Tables 5.3 with 5.2 indicates that:

- Capital costs are estimated to be substantially higher than for a conventional vehicle, arising from increased cost both for the basic vehicle and for other drive train components, including the battery;

- Fuel costs for electric vehicles are lower, but battery replacement costs are higher leading, overall, to a modest reduction in operating costs;

- Emission costs are significantly reduced (below those from biofuel E-100 overall); 
- A Life Cycle cost higher than for a Conventional Car, but still within 10 percent thereof.

\subsection{Reference Fuel Cell/Battery Car Case}

On the spreadsheet, fuel cell/battery vehicles can be compared using a number of variables. These include:

- Fuel cell type, either methanol or hydrogen fueled; proton electron membrane technology;

- Accompanying generic battery performance (high, medium or low);

- Three different types of motors and motor controllers, namely alternating current, direct current brushless, and direct current brush; and

- An overall indication of battery technology of either high or low.

In order to focus on the fuel cell type, and the factors which are technology and cost specific to that type, a Reference Fuel CelnBattery Case is defined here which uses a medium performance battery with high technology and a direct current brushless motor. Table 5.4 shows the complete life cycle cost results for these Reference Fuel Cell vehicles, fueled with either methanol or hydrogen.

The comparison with the previous tables indicates that:

- The PEM fuel cell vehicles have the highest life cycle costs; however, most of this differential is in the other components category of the Capital Cost category, and hence should be subject to reduction through research and development; and

- The PEM fuel cell vehicles have the lowest calculated emission costs; hence, they have strong attractiveness on a long-term basis as environmentally superior vehicles; the hydrogen-fuel PEM reduced emissions (relative to the Reference Conventional Car) by more than a factor of ten. 
Table 5.4: Total Life Cycle Costs PEM Reference Case Fuel Cell/Battery Cars

\begin{tabular}{|c|c|c|}
\hline \multirow[b]{2}{*}{ Cost Item } & \multicolumn{2}{|c|}{ Fueled By } \\
\hline & Methanol & Hydrogen \\
\hline \multicolumn{3}{|l|}{ Capital Cost } \\
\hline Basic Vehicle & $\$ 11,141$ & $\$ 12,324$ \\
\hline Other Components & $\$ 9,439$ & $\$ 11,341$ \\
\hline Accessories & $\$ 2,500$ & $\$ 2,500$ \\
\hline Salvage & $\$(946)$ & $\$(525)$ \\
\hline Total Capital & $\$ 22,134$ & $\$ 25,640$ \\
\hline \multicolumn{3}{|l|}{ Operating Cost } \\
\hline Fuel & $\$ 2,917$ & $\$ 6,763$ \\
\hline Repairs/Maintenance & $\$ 7,050$ & $\$ 2,812$ \\
\hline Replacement & $\$ 1,946$ & $\$ 1,946$ \\
\hline Insurance & $\$ 4,789$ & $\$ 4,785$ \\
\hline Garage/Park/Tolls & $\$ 663$ & $\$ 663$ \\
\hline Title/Register/License & $\$ 845$ & $\$ 935$ \\
\hline Total Operating & $\$ 18,207$ & $\$ 17,906$ \\
\hline \multicolumn{3}{|l|}{ Emissions Cost } \\
\hline $\mathrm{HC}$ & $\$ 82$ & - \\
\hline $\mathrm{CO}$ & $\$ 11$ & - \\
\hline $\mathrm{NO}_{\mathrm{x}}$ & $\$ 394$ & - \\
\hline Particulates & & - \\
\hline $\mathrm{SO}_{2}$ & - & - \\
\hline Aldehydes/BTX & $\$ 6$ & - \\
\hline $\mathrm{CO}_{2}$ Equivalent & $\$ 221$ & $\$ 203$ \\
\hline Total Emissions & $\$ 715$ & $\$ 203$ \\
\hline Total Life Cycle Cost & $\$ 41,056$ & $\$ 43,748$ \\
\hline
\end{tabular}




\subsection{SENSITIVITY ANALYSIS/IMPACT ASSESSMENT}

\subsection{Initial Rank Order of Case Results}

The results of the previous section may be summarized for the Reference Vehicles and Default Assumptions of the Model in terms of the initial rank order listing shown in Figure 6.1.

Figure 6.1: Initial Rank Order Listing

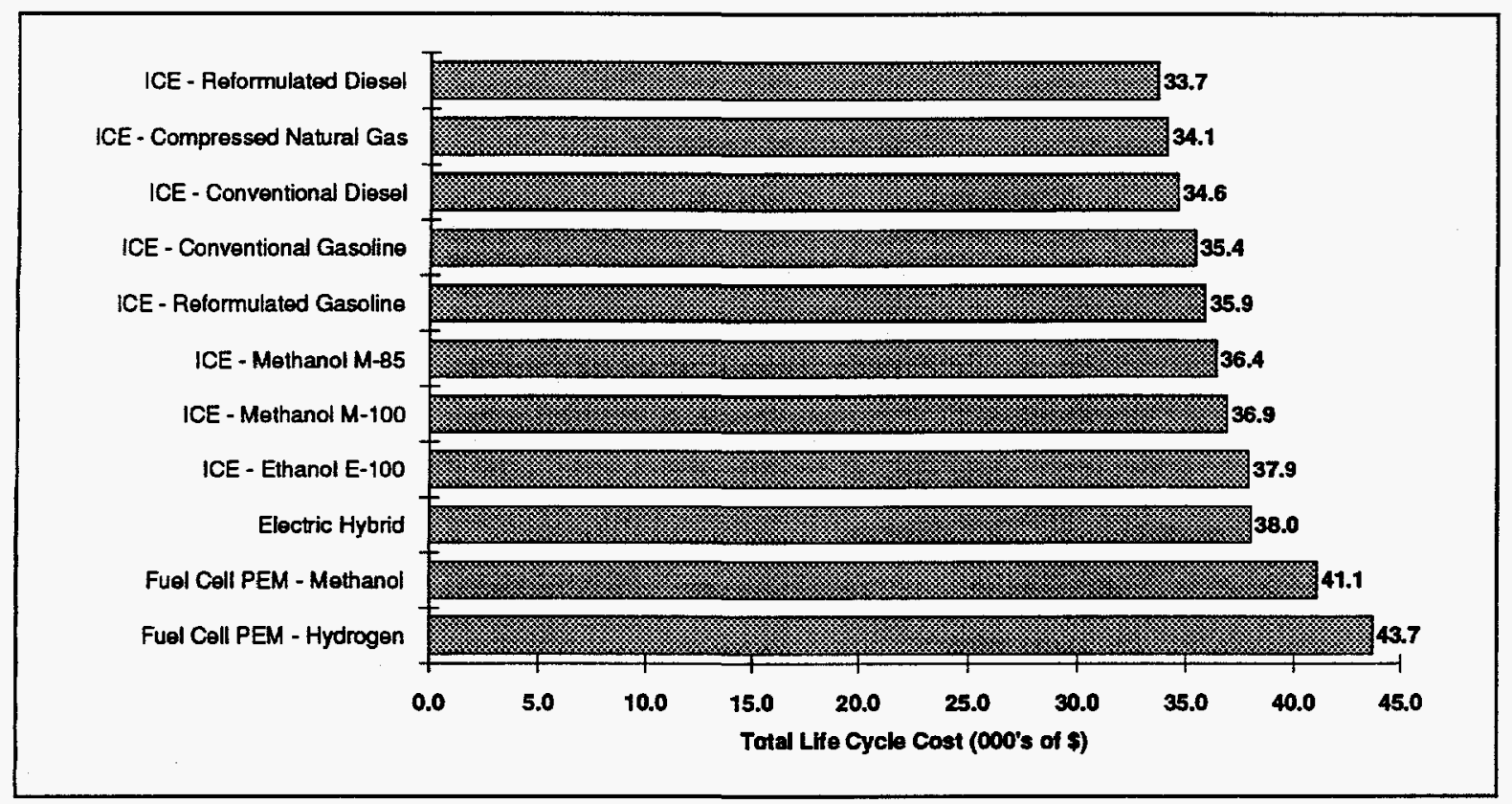

Thus, all of the ICE cases, and the Reference Electric Vehicle, are within plus or minus 10 percent of the ICE - (Reformulated or Conventional) Gasoline current technology case. Since it is doubtful that advanced technology estimates are accurate within plus or minus 10 percent, this is equivalent to saying that there is no clear basis on which to judge the actual relative merits of those developmental concepts which are within this error band.

For the Fuel Cell PEM Vehicles, which are outside the 10 percent range, it is understood that these concepts are still in the early stages of development, as compared to the Alternative - Fuel ICE Vehicle. Accordingly it should be noted that the differential life cycle cost of some $\$ 6,000$ $\$ 8,000$ (relative to the ICE - gasoline cases) is only about a 20 percent premium. A cost reduction of this magnitude, as the result of successful $R \& D$, is a credible target. 


\subsection{Result of Capital Cost Exclusions}

It just might be asked as to how rankings would be changed if the major components of the capital cost were excluded from the comparison. In terms of Model operation, this means that the Other Inputs dialog box is brought up, and the entries therein for Base Vehicle Cost and Accessories Cost are set to zero. Retaining other default assumptions, we obtain the revised rank order listing for Life Cycle Cost as shown in Figure 6.2.

Figure 6.2: Revised Rank Order Listing

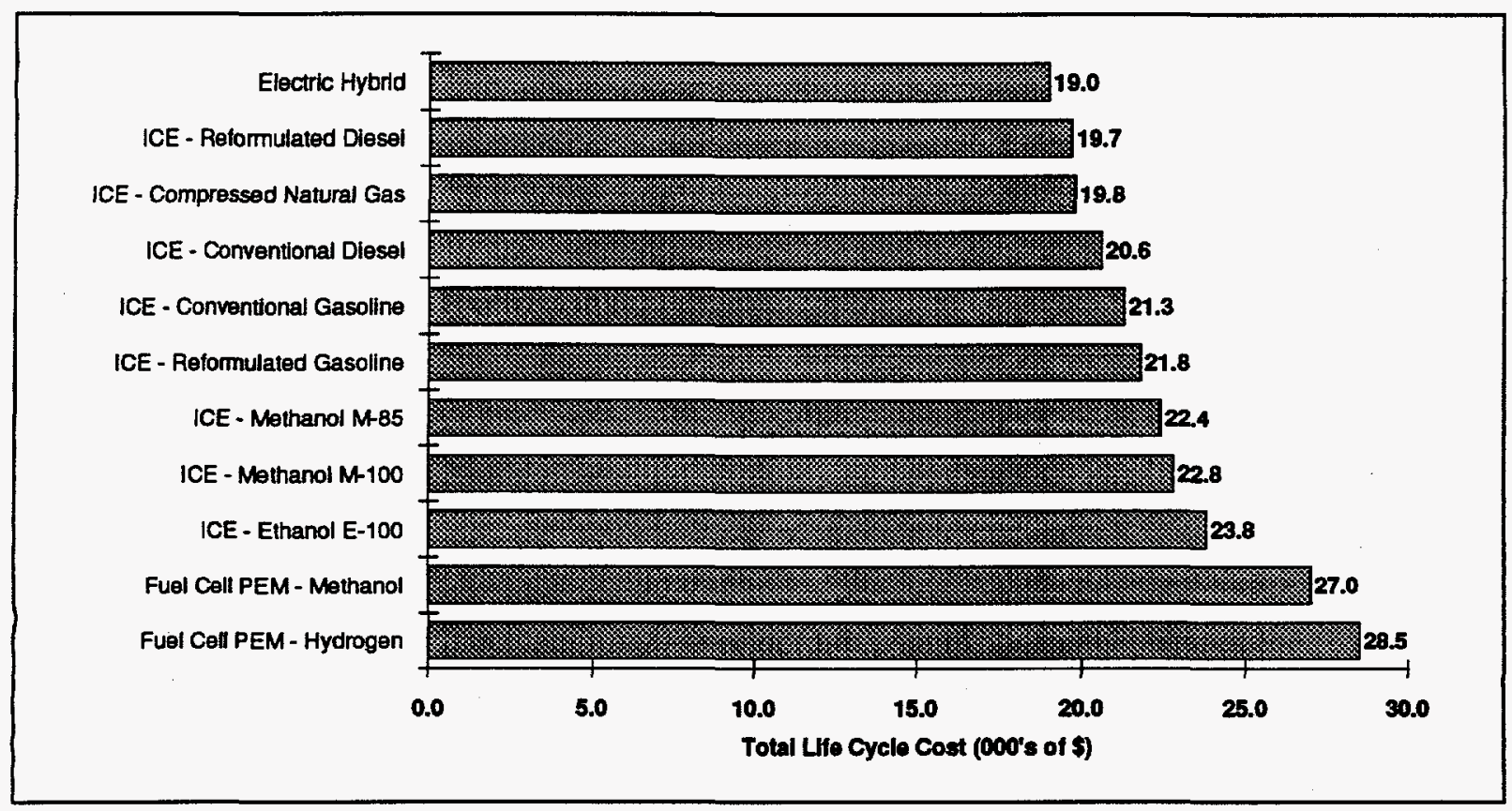

Thus, electric vehicles move from ranking order ninth on Figure 6.1 to ranking order first in Figure 6.2. All other rank orders remain the same. The dollar differential for Fuel Cell vehicles relative to the ICE remains the same as previously, but is therefore a larger percentage of the costs which are being counted. The size of the premium, however, is still within the range of being a credible R\&D target.

The indication that the rank ordering of the electric vehicle concept may be highly dependent on vehicle weight (since the cost component depends on that weight times the Base Vehicle Cost in $\$ /$ kilogram which we have set to zero for this sensitivity study) suggests that reduction of weight, and component complexity which may contribute to capital cost, should be one key target 
of electric vehicle $R \& D$.

\subsection{Energy Security Premium}

As indicated previously, the default energy security premium for imported oil is set at $\$ 25$ per barrel of crude oil. If this premium is set to zero, it makes the Reference ICE (Conventional Gasoline) case lower in cost. Specifically, the Life Cycle Cost (retaining the capital cost exclusion) then falls from 21.3 to 20.1 thousands of dollars. Conversely, if the premium is raised to $\$ 100$ per barrel, the life cycle cost increases to 24.9 thousands of dollars. In the former case, the Compressed Natural Gas vehicle is still of higher rank than the gasoline vehicle; hence, the inclusion of a moderate energy security premium has relatively little impact on ranking. However, a significantly stronger level of concern about imports and domestic jobs will make all non-import-dependent ICE vehicles appear more attractive than petroleum-based ICEs.

\subsection{Total Environmental Emissions}

If, in addition to the capital cost exclusion and a zero energy security premium, zero avoided costs for all environmental emissions are imposed, is it easier to focus essentially on other operating costs (including fuel costs) as the basis for comparison. The resulting rank ordering is shown is Figure 6.3.

The relatively lower life cycle cost for conventional and reformulated gasoline in this listing clearly illustrates that the conceptual benefits associated with pursuing higher capital or fuel costs for alternative fuel vehicles are associated with emission reductions from conventional fuel cycles which can offset such higher expenditures.

Of particular interest in the above listing is the fact that compressed natural gas and electric hybrid vehicles appear to be within 10 percent of the cost of conventional fuel vehicles, insofar as operating costs are concerned. This suggests that further reductions in emissions associated with these concepts would significantly add to their attractiveness. Unfortunately the fuels generating the lowest emission levels (biomass-based ethanol and hydrogen) show high fuel production and operating costs which undermine the economic value of their relative cleanliness. 
Figure 6.3 Rank Order Listing with Additional Parameters

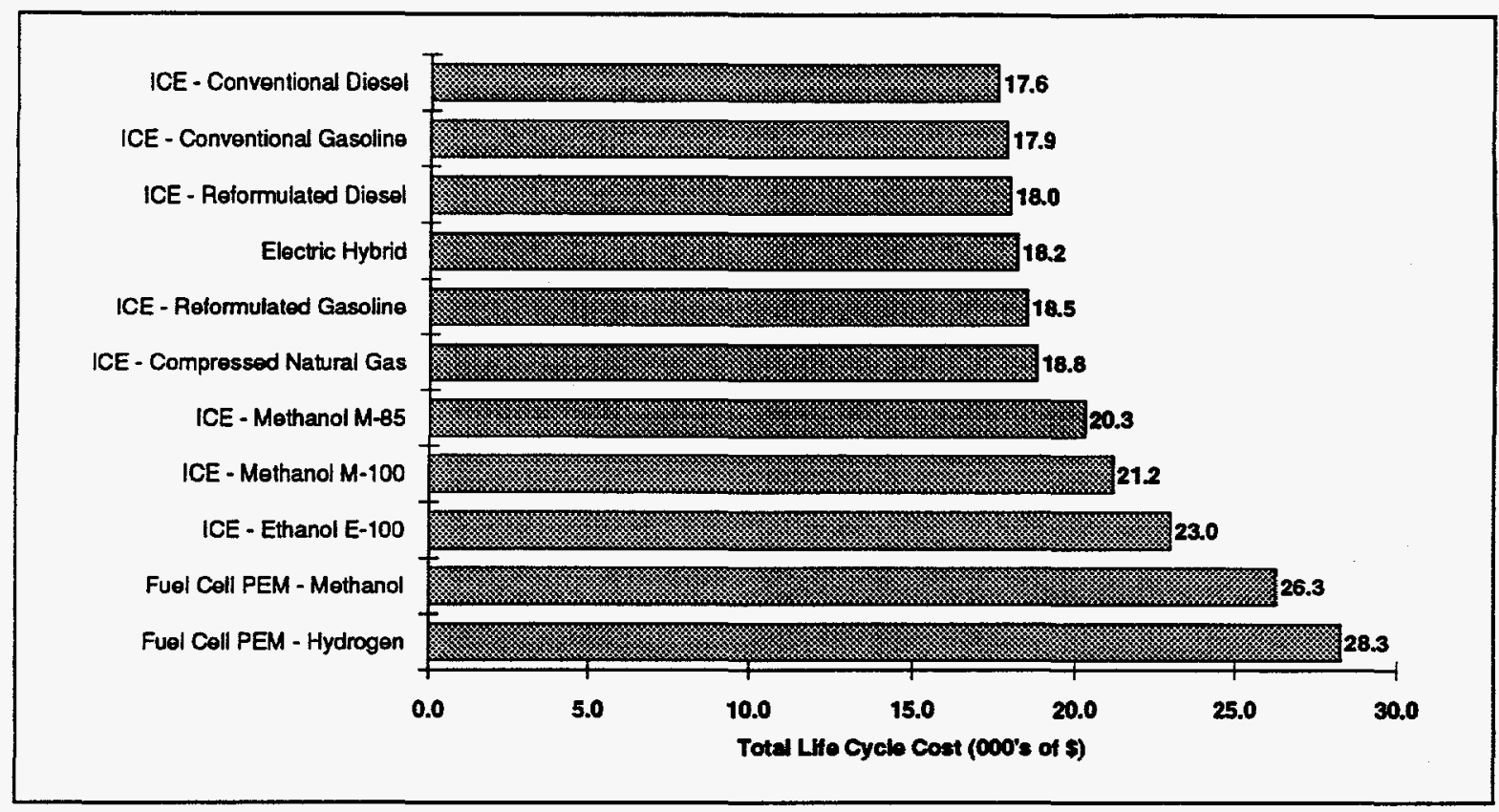

This consideration again identifies a significant R\&D target, if development pathways for fuel cost reduction can be defined.

The focus on emission reductions and resulting avoided cost is further validated from this data by noting that, for conventional gasoline ICEs, the default value of the energy security premium is $\$ 1.2$ thousands in life cycle cost (refer to section 6.3 and the difference between $\$ 21.3$ and 20.1 thousands), whereas the differential for deletion of all environmental emissions is $\$ 2.2$ thousands ( $\$ 20.1$ less the value of $\$ 17.9$ thousands shown in the rank listing above in this section 6.4). Hence, the default avoided emissions costs have close to twice the value of the energy security premium.

As a final sensitivity test for avoided costs considered as an integral set, one examines how rankings may change if all of the penalties (including the energy import premium) were twice their default values. It could be accomplished by retaining the capital exclusion so that these new results may be compared with the data already presented in sections 6.2 and earlier in this section 6.4. Rather than all eleven vehicle/fuel types, one focuses for simplicity on five: conventional gasoline, compressed natural gas, ethanol, electric and the hydrogen fuel cell. The comparative life cycle costs in thousands of dollars are presented in Table 6.1. 
Table 6.1 Comparative Life Cycle Costs Data (Absolute Values)

\begin{tabular}{||l|c|c|c||}
\hline \multirow{2}{*}{ Vehicle Type/Fuel } & \multicolumn{3}{|c|}{$\begin{array}{c}\text { Life Cycle Cost (000's of \$) } \\
\text { (Capital Excluded) }\end{array}$} \\
\cline { 2 - 4 } & $\begin{array}{c}\text { No Emission } \\
\text { Penalties }\end{array}$ & $\begin{array}{c}\text { Default } \\
\text { Avoided Costs }\end{array}$ & $\begin{array}{c}\text { Double } \\
\text { Default } \\
\text { Values }\end{array}$ \\
\hline \hline ICE - Gasoline & & 21.8 & 24.7 \\
ICE - Natural Gas & 17.9 & 19.8 & 21.0 \\
ICE - Ethanol & 18.8 & 23.8 & 24.7 \\
Electric & 23.0 & 19.0 & 19.8 \\
Fuel Cell - $\mathrm{H}_{2}$ & 18.2 & 28.5 & 28.7 \\
\hline
\end{tabular}

By retabulating these results, and entering the relative rankings of the five concepts for each of the three assumptions about the value of avoided costs, the results are shown in Table 6.2

Table 6.2 Comparative Life Cycle Costs Data (Relative Values)

\begin{tabular}{||l|c|c|c||}
\hline & \multicolumn{3}{|c|}{$\begin{array}{c}\text { Life Cycle Ranking } \\
\text { (Capital Excluded) }\end{array}$} \\
\cline { 2 - 4 } \multicolumn{1}{|c|}{ Vehicle Type/Fuel } & $\begin{array}{c}\text { No Emission } \\
\text { Penalties }\end{array}$ & $\begin{array}{c}\text { Default } \\
\text { Avoided Costs }\end{array}$ & $\begin{array}{c}\text { Double } \\
\text { Default } \\
\text { Values }\end{array}$ \\
\hline \hline ICE - Gasoline & 1 & 3 & $3-4$ \\
ICE - Natural Gas & 3 & 2 & 2 \\
ICE - Ethanol & 4 & 4 & $3-4$ \\
Electric & 2 & 1 & 1 \\
Fuel Cell - $\mathrm{H}_{2}$ & 5 & 5 & 5 \\
\hline
\end{tabular}

As noted earlier, natural gas and electric vehicles appear superior to conventional gasoline when default values of avoided costs are considered. Hence, the inclusion of avoided costs leads to a significant result. Next, when the value of these costs are doubled, conventional gasoline vehicles appear even worse. However, much larger (and therefore not highly credible) changes in avoided costs would be needed before the cleanest fuels (biofuel ethanol and hydrogen) would appear economically competitive with either natural gas or electric fuels, even though these latter concepts do indeed release some undesirable emissions. 
This sensitivity test reinforces the earlier conclusion that selected major R\&D targets for the cleaner fuel concepts are associated with reducing the cost of fuel for ethanol, and reducing both the fuel cost and component weight and/or capital cost for the hydrogen fuel cell.

\subsection{Fuel Costs}

Returning now to a base condition of default avoided costs, and retaining the capital exclusion, one examines the significance of doubling fuel costs for gasoline, electricity and/or natural gas on the one hand, and/or halving the fuel cost for ethanol and/or hydrogen on the other hand. These results, expressed as life cycle costs, are shown in Table 6.3.

Table 6.3 Life Cycle Costs Altered Values

\begin{tabular}{||l|c|c|c||}
\hline \multirow{2}{*}{\multicolumn{1}{|c|}{ Vehicle Type/Fuel }} & \multicolumn{3}{|c|}{$\begin{array}{c}\text { Life Cycle Cost (000's of \$) } \\
\text { (Capital Excluded) }\end{array}$} \\
\cline { 2 - 4 } & $\begin{array}{c}\text { Halved } \\
\text { Fuel Cost }\end{array}$ & $\begin{array}{c}\text { Default } \\
\text { Fuel Cost }\end{array}$ & $\begin{array}{c}\text { Doubled } \\
\text { Fuel Cost }\end{array}$ \\
\hline \hline ICE - Gasoline & 18.4 & 21.8 & 27.2 \\
ICE - Natural Gas & 17.2 & 19.8 & 25.1 \\
ICE - Ethanol & 19.0 & 23.8 & 33.6 \\
Electric & 17.6 & 19.0 & 21.7 \\
Fuel Cell - $\mathrm{H}_{2}$ & 25.1 & 28.5 & 35.3 \\
\hline
\end{tabular}

Under the stated assumptions, Table 6.3 reveals the following:

- Even if hydrogen fuel costs are halved, they do not make the fuel cell concept economically equivalent unless other fuel costs are significantly increased (or, in the case of natural gas, doubled);

- After electric costs have doubled, the electric concept is still viable at default conditions;

- Doubling natural gas costs disadvantages this concept more than doubling electric costs;

- Doubling conventional gasoline costs nearly makes the hydrogen fuel cell viable under its default conditions; and 
- Halving ethanol costs puts this concept in a tie for first place with electric, relative to the default fuel cost assumptions; in general, ethanol's relative position is the most sensitive to fuel cost.

\subsection{Specific Emission Types}

Obviously, each alternative fuel vehicle concept achieves a different level and type of emission reduction. One can inquire whether or not a credible revision of avoided cost values might radically alter the relative ranking of the concepts.

To simplify the analysis three groupings of emissions are used as follows:

- Greenhouse gases, expressed as $\mathrm{CO}_{2}$ equivalent, and designated as GHG;

- Non-hydrocarbon chemicals, consisting of $\mathrm{NO}_{\mathrm{x}}$ and $\mathrm{SO}_{2}$, and designated as $\mathrm{NHC}$; and

- All other contaminants, consisting of $\mathrm{HC}, \mathrm{CO}$, particulates, aldehydes and BTX, and designated as AOC.

The dollar values associated with avoided costs for these groupings, for the five illustrative vehicle type/fuel concepts, are shown in Table 6.4 .

Table 6.4 Avoided Cost Comparative Values

\begin{tabular}{||l|c|c|c|c||}
\hline \multirow{2}{*}{\multicolumn{1}{|c|}{ Vehicle Type/Fuel }} & \multicolumn{4}{|c|}{$\begin{array}{c}\text { Avoided Cost Component of Life } \\
\text { Cycle Cost (000's of \$) }\end{array}$} \\
\cline { 2 - 5 } & GHG & NHC & AOC & Total \\
\hline \hline ICE - Gasoline & 0.68 & 0.23 & 1.28 & 2.19 \\
ICE - Natural Gas & 0.61 & 0.30 & 0.21 & 1.21 \\
ICE - Ethanol & 0.22 & 0.10 & 0.55 & 0.87 \\
Electric & 0.64 & 0.11 & 0.04 & 0.79 \\
Fuel Cell - $\mathrm{H}_{2}$ & 0.20 & - & - & 0.20 \\
\hline
\end{tabular}


By inspection, and relative to gasoline:

- Natural gas generates a major decrease in the AOC category; so does electric, but the latter also significantly reduces the NHC component as well;

- Ethanol from biofuel generates a major decrease in the GHG category, and also halves NHC; the hydrogen fuel cell also displays similar GHG benefits, but then goes on to reduce NHC and AOC emissions to zero.

From the standpoint of economic impacts:

- If the NHC component is undervalued, it could prove to be as significant an economic determinant as GHG; in such circumstances, biofuels and electric alternatives would appear much more attractive than natural gas;

- If the GHG component is undervalued, the most important technology concepts could prove to be biofuels and fuel cell; and

- If the AOC is undervalued, the most important technology concepts could prove to be electric and fuel cells.

Thus, while natural gas systems may have the best near-term potential (because they combine immediate pollution reduction with reasonable capital, fuel and other operating expenses), the more critical longer-term technologies appear to be found in the diverse set of the electric, biofuels and fuel cell concepts.

In order to aid the acquisition of sustained R\&D funding so that technical and cost issues can be addressed, it may be useful to target some R\&D funds at obtaining a much better understanding of avoided cost penalties, so as to assess better the key aspects of relative benefit associated with each of the three most interesting competitors.

Obviously, it would also appear desirable to analyze better the likelihood that the needed weight/capital/performance/fuel cost etc. R\&D targets can actually be achieved for each of the concepts, including a probabilistic estimate of the time and cost necessary to achieve these results with reasonable certainty. 


\subsection{CONCLUDING REMARKS}

The discussions in the preceding sections illustrate the capability which resides in the Model to explore a variety of comparative policy issues relating to costs, benefits and $R \& D$ targets. Additional features can readily be incorporated to examine still other questions and issues.

For example, in order to facilitate user control and conduct sensitivity studies of other-thandefault fuel costs, an entry for a factor by which to multiply such default values was created on the Other Inputs dialog box. This box reports its entry into cell J38 of the MENUS page. A default value of 1 was placed in cell K38. The default range was extended to K38 to include that new cell by invoking the Block Names Create dialog box from the main Quattro Pro menu, clicking on the listed DEFAULT range, and editing the range definition in the window provided for this purpose. The clarifying text used to label the fuel cost multiplier was added to the Other Inputs dialog box by going to the Quattro Pro graph page and editing Dialog 6 (the system name for the Other Inputs dialog box) which resides on that page. Finally, the variable factor by which fuel cost is to be multiplied was introduced into the equation for fuel cost (in $\$$ per liter) which appears on the ENERGY page in cell B5. This equation now includes the factor which is reported from the Other Inputs entry system into cell J38 of the MENUS page. Pressing the Restore Defaults button on the Speed Bar resets this factor to one.

Similar processes can be used to incorporate additional areas of user control. Three "reserved" (unused) entry boxes in the Other Inputs dialog box have been left available for this purpose.

The use of Embedded Data Sets which the user may overwrite (thus providing for easy updating of the Model), and the open architecture of the system (thus providing for future representation of any subarea in additional detail without having to modify other parts of the Model) should allow the Model to retain both currency and validity over time. The Embedded Data Sets should be routinely updated for this purpose. The current values of the Embedded Data Sets are shown in Appendix C.

The life cycle cost sensitivity analysis has identified various key elements for comparative analysis. These should now be modeled and examined in greater detail. Future versions could 
also incorporate representations of the $R \& D$ process (steps, cost and time) estimated to be required to achieve the target performance and cost objectives. The inclusion of probability features would enhance the ability to explore the value of alternative funding levels for the various $R \& D$ targets. The benefit information in the Model is for a single vehicle lifetime. This information needs to be combined with penetration curves to evaluate absolute benefits and to allow the calculation of benefit/cost ratios for $R \& D$ programs. 


\section{APPENDIX A - BIBLIOGRAPHY}

1. Life-Cycle Cost Analysis of Conventional and Fuel Cell/Battery Powered Urban Passenger Vehicles; U.S. Department of Energy; 1992

2. MacKenzie, James; The Key to the Car; World Resources Institute, 1994

3. Emissions of Greenhouse Gases from the Use of Transportation Fuels and Electricity, Volume I; Argonne National Laboratory, DE-92-012102, 1991

4. Cars and Climate Change; International Energy Agency, 1993

5. MacKenzie,James, et al; Car Trouble; World Resources Institute, 1993

6. Delucchi, Mark; Hydrogen Fuel-Cell Vehicles; Institute of Transportation Studies, University of California, UCD-ITS-RR-92-14, 1992

7. European Workshop on the Emission of Nitrons Oxide; National Laboratory of Energy and Industrial Technology, Portugal; 1990

8. Fuel Cycle Evaluations of Biomass-Ethanol and Reformulated Gasoline; National Renewable Energy Laboratory, NREL-TP-463-4950, 1993

9. First Interim Report of the Interagency Commission on Alternative Motor Fuels; 1990

10. Biodiesel, A Technology Performance and Regulatory Overview; National Soy Diesel Development Board, 1994

11. Particles in Air Help Kill 60,000 a Year, Study Says; Washington Post; May 13, 1991

12. Air Pollution Standards May Need Tightening, Study Says; Washington Post, December 9, 1993

13. Breath in Danger II; American Lung Association; 1989

14. Evaluation of Alternative Transportation Fuels and Vehicles; U.S. Department of Energy; 1990

15. Substitute Fuels for Road Transport; International Energy Agency; 1990

16. Potential Emissions and Air Quality Effects of Alternative Fuels - Final Report; Sierra Research, SR89-03-04, 1989

17. The Gassing of America; Washington Post; April 13, 1990 
18. Emissions of Greenhouse Gases from the Use of Transportation Fuels and Electricity, Volume 2: Appendixes A-S, Argonne National Laboratory, ANL/ESD/TM-22, Vol. 2, 1992

19. Proposed Reactivity Adjustment Factors for Transitional Low-Emission Vehicles; California Air Resources Board; 1991

20. Environmental Externalities in the Electric Utility Sector; Department of Energy draft, 1992

21. MacKenzie, James, et al; the Going Rate; World Resources Institute, 1992

22. Darmstadter, fuel; Estimating the Cost of Carbon Dioxide Abatement; Resources for the Future, No. 103, Spring 1993

23. Weyant, John; Costs of Reducing Global Carbon Emissions; Journal of Economic Perspectives, Volume 7, No. 4, Fall 1993

24. Proceedings, National Conference on Environmental Externalities; National Association of Regulatory Utility Commissioners, 1990

25. Benefits and Costs for an Enhanced Transportation R\&D Funding Level; U.S. Department of Energy draft; 1990

26. Edlestine, R., Proposed Quantification of Air Emission Benefits; Gas Research Institute, Private Communication, 1993

27. Acid Rain Compliance Strategies for the Clean Air Act Amendments of 1990; Energy Information Administration, DOE/EIA-0582, 1994

28. EPA Tells Chemical Plants to Cut Toxic Emission 88\%; Washington Post; March 2,1994

29. Harrington, W, et al; Shifting Gears: New Directions for Cars and Clean Air; Resources for the Future, No. 115, Spring 1994

30. Alberini, Anna, et al; Will Speeding the Retirement of Old Cars Improve Air Quality?; Resources for the Future, No. 115, Spring 1994

31. The Price of Mobility; Natural Resources Defense Council, 1993

32. Monthly Energy Review; Energy Information Administration; April 1993

33. Wooley, R., et al; First Semi-Annual Report, AFDC Light Duty Vehicles; National Renewable Energy Laboratory, 1993

34. Patil, P. et al; Energy, Environmental and Economic Benefits; Fuel Cell Program and Abstracts, 1992 


\section{APPENDIX B - PRIOR BIBLIOGRAPHY}

\section{Reports}

1. Humphreys, K.K., and D.R. Brown, Life-Cycle Cost Comparisons of Advanced Storage Batteries and Fuel Cells for Utility, Stand-Alone and Electric Vehicle Applications, prepared by Pacific Northwest Laboratory, Richland, Washington for the U.S. Department of Energy, January 1990 (PNL-7203, UC 212).

2. Theodore Barry \& Associates, A Comparative Analysis of Electric Vehicles and Other Alternative Clean Fuel Vehicles for Southern California Edison, September 1989.

3. Takagishi, S.K., Life-Cycle Cost Comparison, Proceedings of the 9th Electric Vehicle Symposium, Toronto, Ontario, Canada on November 13-16, 1988.

4. Brunner, J.W., et al, Electric Vehicle Development Corporation, Estimated Life-Cycle Costs for Electric and Conventional Vans, prepared for U.S. Department of Energy, July 1987.

5. Booz-Allen \& Hamilton, Inc., Comparison of Life-Cycle Costs of Alternative Fuel Vehicles, prepared for U.S. Department of Energy, Washington, D.C., December 1988.

6. Idaho National Engineering Laboratory and EG\&G Idaho, Inc., An Approach for Testing Fuel Cell/Battery Hybrid Power Sources for Bus Applications, prepared for the U.S. Department of Energy, May 1989.

7. Electric and Hybrid Vehicles Program, 14th Report to Congress for Fiscal Year 1990, U.S. Department of Energy, Washington, D.C., February 1991.

8. Lindquist, J., et al, "Electric Vehicle Cost Competitiveness in the United States and Europe: Implications for the U.S. Electric Vehicle Industry," Proceedings of the 10th Electric Vehicle Symposium held in Hong Kong in 1989, pp. 10001006.

9. Murray, H.S., and J.R. Huff, Fuel Cell/Battery Hybrid Vehicle Assessment, Los Alamos National Laboratory, Los Alamos, New Mexico, October 1987 (LA-10948-MS, UC96).

10. Patil, P.G., Electric Vehicle Battery and Fuel Cell Research and Development Program, U.S. Department of Energy, August 1989.

11. Sheladia Associates, Inc., Assessment of Battery and Fuel CelliBattery Technologies for Electric Vehicles, prepared for Idaho National Engineering Laboratory, U.S. Department of Energy, April 1988. 
12. U.S. Department of Energy, Mission Directed Goals for Electric Vehicle Battery Research and Development: The Task Force on Electric Vehicle Battery Goals, November 1987 (DOE/CE-0148).

13. Henriksen, G.L., et al, National Program Plan for Electric Vehicle Battery Research and Development: Technical Plan, Idaho National Engineering Laboratory, U.S. Department of Energy, Washington, DC, August 1989, (DOE/ID-10219, UC-331).

14. Program Plan for Research and Development and Demonstration of a Fuel Cell/Battery Powered Bus System, U.S. Department of Energy and U.S. Department of Transportation, January 1987.

15. Patil, P.G., The U.S. DOE Electric Vehicle Battery Research and Development Program, U.S. Department of Energy, Washington, DC (Date unknown).

16. Barber, K.F., and S.K. Takagishi, "The U.S. Department of Energy's Electric Vehicle Product Improvement Program," Proceedings of the 9th Electric Vehicle Symposium held in Toronto, Ontario, Canada on November 13-16, 1988.

17. Hsu, D., and J. Duncan, "Griffon Electric Vans in Courier Service at the Ministry of Transportation," Proceedings of the 9th Electric Vehicle Symposium held in Toronto, Ontario, Canada on November 13-16, 1988.

18. Romano, S., "Design Considerations for a Fuel CelliBattery Powered Transit Bus," Proceedings of the 9th Electric Vehicle Symposium held in Toronto, Ontario, Canada on November 13-16, 1988.

19. Spindler, W.C., et al, "Opportunities for Optimizing EV Battery Performance, Battery Specific Power, and Vehicle Equivalent Electric Circuit Considerations," Proceedings of the 9th Electric Vehicles Symposium held in Toronto, Ontario, Canada on November 13-16, 1988.

20. Ratner, E.Z., et al, "Assessment of Battery Technologies for EV Applications," Proceedings of the 9th Electric Vehicle Symposium held in Toronto, Ontario, Canada on November 13-16, 1988.

21. Kevala, R.J., "Conceptual Design of a Fuel Cell/Battery-Powered Bus System," Proceedings of the 9th Electric Vehicle Symposium held in Toronto, Ontario, Canada on November 13-16, 1988.

22. Brown, P.J., et al, "Overview of U.S. Government Programs on Electric Vehicles," pp. 271-275 (Report No. 889285).

23. Patil, P.G., et al, "Integration of a Fuel Cell/Battery Power Source in a Small Transit Bus System," pp. 227-231 (Report No. 889120). 
24. Romano, S., "The Fuel Cell Powered Bus-The Answer to An Unlimited Range Electric Vehicle" Proceedings of the 10th Electric Vehicle Symposium held in Hong Kong on December 3-5, 1990, pp. 682-691.

25. Kevala, R.J. and M.Y.C. Woo, "Design of a Fuel Cell/Battery Powered Transit Bus," Proceedings of the 10th Electric Vehicle Symposium held in Hong Kong on December 3-5, 1990. pp. 678-681.

26. Parkash, C.B., et al, "Electric Vehicles and the Environment," Proceedings of the 10th Electric Vehicle Symposium held in Hong Kong on December 3-5, 1990, pp. 10131029.

27. Gosden, D.F., "Electric Vehicles and the Greenhouse Effect," Proceedings of the 10th Electric Vehicle Symposium held in Hong Kong in December 3-5, 1990, pp. 10521065.

28. Risser, R., and O. Bevilacqua, "PG\&E's Evaluation of the Electric A-Van," Proceedings of the 10th Electric Vehicle Symposium held in Hong Kong on December 3-5, 1990 , pp. 818-830.

29. Wang, Q.L., and M.A. Deluchi, "Comparison of Primary Energy Consumption by Gasoline Internal Combustion Engine Vehicles and Electric Vehicles," Proceedings of the 10th Electric Vehicle Symposium held in Hong Kong in December 3-5, 1990, pp. 898-912.

30. Gris, A. and S.E. Shladover, "Evaluation of Potential Hybrid Electric Vehicle Applications," Proceedings of the 10th Electric Vehicle Symposium held in Hong Kong on December 3-5, 1990, pp. 722-737.

31. Patil, P.G., et al, "U.S. Research \& Development Program on Fuel Cells for Transportation Applications," Proceedings of the 10th Electric Vehicle Symposium held in Hong Kong on December 3-5, 1990, pp. 657-669.

32. Adams, W.A., et al, "Electrochemical Propulsion System Efficiency Modelling and Environmental Issues," Proceedings of the 10th Electric Vehicle Symposium held in Hong Kong on December 3-5, 1990, pp. 401-410.

33. Barber, K.F., "An Overview of the Electric and Hybrid Vehicles R\&D Program at the U.S. Department of Energy," Proceedings of the 10th Electric Vehicle Symposium held in Hong Kong on December 3-5, 1990, pp. 24-35.

34. Technology \& Management Services, Inc., Assessment of Potential Technology Exchanges Involving the Electric Vehicle Battery and Fuel Cell Program, prepared for the Argonne National Laboratory, Argonne, Illinois, February 1989.

35. Patil, P. G., et. al, "Shipping, Use, and Disposal/Recycle Considerations for Sodium/Beta Batteries in EV Applications," U.S. Department of Energy, (DE 90 017667, CONF-9006243-3). 
36. Krumpelt, M., and C.C. Christianson, "An Assessment and Comparison of Fuel Cells for Transport Applications," Argonne National Laboratory, Argonne, Illinois, September 1989 (ANL-89/28, DE 90 001807).

37. Hamilton, W., Electric and Hybrid Vehicles, prepared for EG\&G Idaho, Inc., and U.S. Department of Energy, July 1989 (DE 90 002218, DOE/ID-10252).

38. Kumar, R., "Requirements for a Fuel Cell for Transportation Applications," Proceedings of the Direct Methanol/Air Fuel Cell Workshop held in Washington, DC on May 14-16, 1990.

39. Krumpelt, M., and P.G. Patil, U.S. Department of Energy, Proceedings of the Second Annual Fuel Cells Contractors Review Meeting held at Morgantown, West Virginia on May 2-3, 1990, pp. 193-203.

40. Ratner, E. Z. (Organizer), Assessment of Battery Technologies for Electric Vehicles, Volume II - Appendices, Part I \& II, Prepared for EG\&G, Idaho, Inc. and U.S. Department of Energy, Washington, DC, February 1990.

41. Report on the Alternative Motor Fuels, The Interagency Commission on Alternative Motor Fuels and the U.S. Alternative Fuels Council, 1990.

42. Patil, P.G., "Prospects for Electric Vehicles," Proceedings of the 25th IECEC, Reno, Nevada, August 1990.

43. Christianson, C.C., et. al, "Electric Vehicle Battery and Fuel Cell Program at $A N L$," DOE/Laboratory Project Review and Coordination Meeting, Argonne, Illinois, September 1990.

44. DeLuca, W.H., et. al, "Performance Evaluation of Advanced Battery Technologies for Electric Vehicle Application," Proceedings of the 25th IECEC, Volume 3, Reno, Nevada, August 1990.

45. Krumpelt, M., and R. Kumar, "Assessment of Fuel Cells for Transportation", Extended Abstracts, Ninth Battery and Electrochemical Contractors Conference, Alexandria, Virginia, November 1989

46. Deluchi, M.A., et. al, "Electric Vehicles: Performance, Life-Cycle Costs, Emissions, and Recharging Requirements," Transportation Research, Volume 22A, No. 5, 1989.

47. Los Alamos National Laboratory, "Fuel Cell Bus Feasibility Study," U.S. Department of Transportation, Washington, D.C., 1986.

48. Booz, Allen \& Hamilton, Inc., Research and Development of a Fuel Cell/Battery Powered Bus System: Phase I Final Technical Report, February 1990 (DOE/CH/10650-01). 
49. Kevala, R.J., "Development of a Liquid-Cooled Phosphoric-Acid Fuel Cell/Battery Power Plant for Transit Bus Applications," Proceedings of the 25th IECEC, Reno, Nevada, August 1990.

50. Roan, V.P., and J. Fletcher, "Transient Performance Modeling and Considerations for a Methanol-Fueled Phosphoric Acid Fuel Cell System Designed for Transportation Applications," Proceedings of the 25th IECEC, Volume 3, Reno, Nevada, August 1990.

51. Chi, C.V., et. al, Research and Development of a Fuel Cell/Battery Powered Bus System: Phase I Final Technical Report, February 1990 (DE-AC08-87NV10714).

52. Chi, C.V., "Air-Cooled Phosphoric Acid Fuel Cell/Ni-Cd Battery Powered Bus," Proceedings of the American Institute of Chemical Engineers Annual Conference, San Francisco, California, November 1989.

53. Chi, C.V., et. al, "Development of a Fuel Cell Power Source for Bus," Proceedings of the 25th IECEC, Volume 3, Reno, Nevada, August 1990.

54. Romano, S., and L.D. Price, "Installing a Fuel Cell in a Transit Bus" Proceedings of the SAE International Congress and Exposition, Detroit, Michigan, February 1990.

55. Romano, S., "The DOE/DOT Fuel Cell Bus Program and its Applications to Transit Missions," Proceedings of the 25th IECEC, Volume 3, Reno, Nevada, August 1990.

56. Budney, P.A., and M.G. Andrew, "Hybrid Lead Acid Battery Power for Today's Electric Vehicles," Proceedings of the Tenth International Electric Vehicle Symposium held in Hong Kong on December 3-5, 1990.

57. Rajan, J.B., et. al, Environmental, Health, and Safety Concerns Associated With Nonpetroleum Fuel Use in U.S. Transportation, Progress Report 1. Argonne National Laboratory, Argonne, Illinois, June 1989 (ANL/ES-163).

58. Hardy, K.S., et. al, Advanced Vehicle Systems Development, Jet Propulsion Laboratory, 1985 (DOE/CS-54209-22).

59. Electric Power Research Institute, Palo Alto, California, Technical Assessment Guide, Volume I, 1986.

60. Consiglio, J.A., and P.C. Symons, Evaluation of Developmental Battery Cost Estimates, Electric Power Research Institute, Palo Alto, California, 1985 (EPRI RP-113624 and -25).

61. Brown, D.R., and J.A. Russell, A Review of Storage Battery System Cost Estimates, Pacific Northwest Laboratory, Richland, Washington, 1986 (PNL-5741). 
62. George, J.H.B., Guidelines for Estimating the Capital Costs of Battery-Based Energy Storage Systems, Electric Power Research Institute, Palo Alto, California, 1984 (RP-1198-2)

63. Pacific Northwest Laboratory, "Battery System Market Penetration and Life-Cycle Cost Estimates," prepared for the U.S. Department of Energy, Richland, Washington.

64. Burke, A.F., "Electric Vehicle Propulsion and Battery Technology 1975-1995," Proceedings of the 25th Intersociety Energy Conversion Engineering Conference, Reno, Nevada, August 12-17, 1990.

65. DeLuchi, M.A., et. al, Hydrogen and Methanol Production From Biomass and Use in Fuel Cell and Internal Combustion Engine Vehicles: A Preliminary Assessment, Center for Energy and Environmental Studies, Princeton University, Princeton, New Jersey, August 1991 (PU/CESS Report No. 263).

66. Kevala, R.J., The Phosphoric Acid Fuel Cell/Battery Bus Project, Program and Abstracts, 1990 Fuel Cell Seminar, November 25-28, 1990, Phoenix, Arizona. pp. 10-13.

67. Abens, S., et al, Air-Cooled Fuel Cell Power Source for Bus, Program and Abstracts, 1990 Fuel Cell Seminar, November 25-28, 1990, Phoenix, Arizona. pp. 28-31.

68. Kumar, R., et al, Methanol Reformers for Fuel Cell Powered Vehicles: Some Design Considerations, Program and Abstracts, 1990 Fuel Cell Seminar, November 2528, Phoenix, Arizona, pp. 76-79.

69. Romano, S., The Fuel Cell Bus Program and its Application to Transit Missions, Program and Abstracts, 1990 Fuel Cell Seminar, November 25-28, 1990, Phoenix, Arizona, pp. 457-461.

70. Braithwaite, J.F., and W.L. Auxer, Status of the DOE-Sponsored Sodium/Sulfur Battery Development Program, Preprints of the Annual Automotive Technology Development Contractor's Coordination Meeting, Volume II, October 28-31, 1991, Dearborn, Michigan.

71. Ohi, J.M., and C.C. Christianson, Environmental Assessment and EV Battery Readiness Working Groups, Preprints of the Annual Automotive Technology Development Contractor's Coordination Meeting, Volume II, October 28-31, 1991, Dearborn, Michigan.

72. Patil, P.G., Fuel Cell Systems R\&D Program Overview, Preprints of the Annual Automotive Technology Development Contractor's Coordination Meeting, Volume II, October 28-31, 1991, Dearborn, Michigan.

73. Kevala, R.J., Fuel Cell/Battery Powered Bus Systems R\&D, Preprints of the Annual Automotive Technology Development Contractor's Coordination Meeting, Volume II, October 28-31, 1991, Dearborn, Michigan. 
74. DeLuca, W.H., et. al, Key Battery Test Results at Argonne National Laboratory, Preprints of the Annual Automotive Technology Development Contractor's Coordination Meeting, Volume II, October 28-31, 1991, Dearborn, Michigan.

75. Tuck, C.D.S. (Editor), Modern Battery Technology, Ellis Horwood Limited, Publisher, New York, October 1991.

76. Ratner, E.Z., et. al, Assessment of Battery Technologies for Electric Vehicles, Volume I, prepared for EG\&G Idaho, Inc., Idaho Falls, Idaho, August 1989 (DOE/ID10243).

77. Fuel Cell Program of the Department of Energy, The Gas Research Institute, and the Electric Power Research Institute, prepared by the Fuel Cell Implementation Committee for the Steering Committee under agreements between the U.S. Department of Energy, the Gas Research Institute, and the Electric Power Research Institute, August 1990.

78. International Energy Agency, Substitute Fuels for Road Transport: A Technology Assessment, 1990.

79. Electric Power Research Institute, "Evaluation of Near-Term Electric Vehicle Battery Systems Through In-Vehicle Testing," Interim Report, Palo Alto, California, December 1986 (EM-4701, Research Project 1136-27).

80. Electric Power Research Institute, "Evaluation of Electric Vehicle Battery Systems Through In-Vehicle Testing," Fourth Annual Report, June 1989 (EPRI-CU6330, Project 1136-27).

81. National Energy Strategy: Powerful Ideas for America, U.S. Department of Energy, Office of Scientific and Technical Information, Oak Ridge, Tennessee, February 1991.

82. Wyczalik, F.A., "GM Electric Vehicle Technology in the 1990's," Proceedings of the 26th Intersociety Energy Conversion Engineering Conference Boston, Massachusetts, August 4-9, 1991. Volume 4, pp. 317-322.

83. Heitner, K.L., "The Range Extender Hybrid Vehicle," Proceedings of the 26th Intersociety Energy Conversion Engineering Conference Boston, Massachusetts, August 4-9, 1991. Volume 4, pp. 323-328.

84. Hagey, G., "The National Fuel Cell R\&D Program and U.S. Markets for Fuel Cell Systems," Proceedings of the 25th IECEC, Volume 3, Reno, Nevada, August 1990.

85. Goldstein, R.H., "Electric Power Research Institute: 1990 Fuel Cell Status," Proceedings of the 25th IECEC, Volume 3, Reno, Nevada, August 1990.

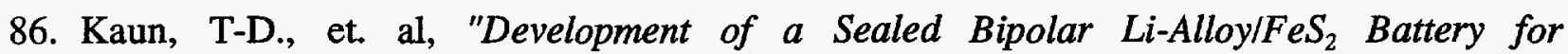
Electric Vehicles," Proceedings of the 25th IECEC, Volume 3, Reno, Nevada, August 1990. 
87. Hudson, C.L., and E.S. Putnam, "Preliminary Energy Use and Economic Analysis of the Aluminum-Air Battery for Automotive Propulsion," Lawrence Livermore Laboratory, April 1980 (UCRL 15242).

88. O'Connel, L.G., et.al, "Energy-storage Systems for Automobile Propulsion: Final Report Volume 2: Energy-storage Devices," Lawrence Livermore National Laboratory December 15, 1980 (UCRL 53063-80, Volume 2).

89. U.S. Department of Energy, "Technical and Economic Assessments of Electrochemical Energy storage systems - Topical Report on the Potential for Savings in Load Levelling Battery and Balance of Plant Costs," August 1985 (DOE/ET/26950 - 1).

90. Chilenskas, A.A., et.al, "A Preliminary Estimate of the Manufacturing Cost for Lithium/Metal sulfide cells for stationary and mobile applications," Argonne National Laboratory, January 1980 (ANL-79-59).

91. Ford Aerospace \& Communications Corporation, "Sodium - Sulfur Battery Development Economic Analysis, Phase IV Topical Status Report" September 1980 (DOE/CH 110012-T1).

92. Clark, R.P., et.al., "Prospects for Advanced Storage Battery Technologies," Sandia National Laboratories, 1984 (SAND-84-07690).

93. Broeck, Van den, "Fuel Cell Development at ELENCO for Vehicle Applications," Proceedings of the 10th Electric Vehicle Symposium held in Hong Kong on December 3-5, 1990 , pp. 670-677.

94. Bobbio, A., et. al, "Hybrid Buses Power Control System," Proceedings of the 10th Electric Vehicle Symposium held in Hong Kong on December 3-5, 1990, pp. 738-750.

95. Miles, R., et.al, "All Electric Hybrid Power Source for Electric Vehicles," Proceedings of the 10th Electric Vehicle Symposium held in Hong Kong on December 3-5, 1990 , pp. 784-794.

96. U.S. Advanced Battery Consortium, 1991.

97. U.S. Department of Energy, Assessment of Costs and Benefits of Flexible and Alternative Fuel Use in the U.S. Transportation Sector, Technical Report Six: Cost of Producing Methanol from Unutilized Domestic Natural Gas, 1991.

\section{Conference Proceedings}

1. Preprints of the Annual Automotive Technology Development Contractors' Coordination Meeting, Dearborn, Michigan, October 28-31, 1991 (Volumes I \& II). 
2. Fuel Cell Program and Abstracts: 1990 Fuel Cell Seminar, sponsored by Fuel Cell Seminar Organizing Committee, Phoenix, Arizona, November 25-28, 1990.

3. Proceedings of the 26th Intersociety Energy Conversion Engineering Conference, Boston, Massachusetts, August 4-9, 1991 (Volume 4).

4. Proceedings of the Seventh Annual Battery Conference on Applications and Advances, Long Beach, California, January 21-23, 1992.

5. Proceedings of 10th Electric Vehicle Symposium (EVS), Hong Kong, December 3-5, 1990.

6. Proceedings of 9th Electric Vehicle Symposium (EVS), Toronto, Canada, November 13-16, 1988.

Newspaper Clippings, Magazine Articles, Weekly Reports, Etc.

1. "Chrysler, Westinghouse to Jointly Build Electric Cars: Companies Hope to Market Vehicle by Late 90s with Greater Speed, Range than Competitors," The Washington Post, March 4, 1992.

2. "Jump-Starting a New Electric Car Battery: Consortium Awards Michigan Firm First Development Contract," The Washington Post, May 20, 1992.

3. "GM Advances Model of Electricity-Run Car: Experts Say Prototype Could Shatter Biases," The Washington Post, January 4, 1990.

4. "Back on the Fast Track: Industrial Progress, New Economic Urgency Signify Light at End of Tunnel for Electric Car," The Washington Post, November 19, 1990.

5. "GM Picks Michigan Plant for Building Electric Car," The New York Times, March 5, 1991.

6. "The Greening of Detroit: A Push is on to Make Cars More Environmentally Friendly," Business Week, April 8, 1991.

7. "Los Alamos Makes Major Breakthrough in Fuel Cell Electric Vehicles," Alcohol Week's New Fuels Report, Volume 12, No. 47, November 25, 1991.

8. "The Stakes are High as Electric Cars Accelerate into the Showroom," Leasley Hazleton, Auto Columnist for Lear's Magazine.

9. "Batteries: Designed by a Team of Visionary Engineers, a Unique New Car is Fast, Sexy and with Zero Emissions--Environmentally Correct for the Nineties," Discover, March 1992. 
10. "Fresh Change of the Electric Brigade," Financial Times, April 11, 1991.

11. "Smart Cars and Highway Go Global," IEEE Spectrum, May 1991.

12. "Auto Oil Research Finds No Immediate Benefits in Use of Gasoline-Methanol Blend," Oil \& Gas Journal, February 24, 1992.

13. "Electric Vehicles: A Clean, Efficient, and Reliable Alternative," $\underline{\text { U.S. }}$ Department of Energy Information, March 1990 (DOE ICE-0289P).

14. "Automotive Newsfront," Popular Science, December 1991.

15. "U.S. Industry Pushes Natural Gas Motor Fuel," Oil and Gas Journal, March 18, 1991.

16. "New Battery Required for Autos of Future: Big Three Turn to Small Michigan Firm for a Fundamentally Different Prototype," The Washington Post, May 25, 1992.

17. "The Push for Advanced Batteries," EPRI Journal, April/May 1991.

18. Electric Vehicle News, September 1991.

19. Electric Vehicle Progress, March 1, 1992.

20. "Fuel Cells: An Overview," Automotive Engineering, Volume 100, No. 4, April 1992.

21. "Contract "Buses" Fuel Cells," Coal \& Synfuels Technology, Volume 12, No. 42, October 28, 1991. 


\section{APPENDIX C - EMBEDDED DATA SETS}

The Model contains the following sixteen (16) Embedded Data Sets:

EDS 1 - Consumer Price Index

EDS 2 - Vehicle Curb Weight

EDS 3 - Electric Drive Systems

EDS 4 - ICE Drive Systems

EDS 5 - Fuel Cell Performance \& Cost Factors

EDS 6 - Battery Performance \& Cost Factors

EDS 7 - Power System Maintenance Factors

EDS 8 - Vehicle Maintenance Factors

EDS 9 - Insurance Factors

EDS 10 - Emissions Cost

EDS 11 - Emissions Allocation

EDS 12 - Fuel Prices

EDS 13 - Import Premium

EDS 14 - Hydrogen Storage Systems

EDS 15 - Hydrogen Fuel Cost

EDS 16 - Performance of Hydrogen PEM Fuel Cells 
EDS 1 is contained in the Finance Module (Model page FINANCE).

EDS 1- Consumer Price Indices

\begin{tabular}{|c|c|c|c|c|c|}
\hline Year & CPI('82=1) & $\begin{array}{l}\text { New Vehicles } \\
(1982-84=100)\end{array}$ & $\begin{array}{c}\text { Motor Fuel } \\
(1982-84=100)\end{array}$ & $\begin{array}{c}\text { Maintenance } \\
\text { \& Repair } \\
(1982-84=100)\end{array}$ & $\begin{array}{c}\text { Insurance } \\
(1982-84=100)\end{array}$ \\
\hline 1980 & 0.82 & 88.50 & 97.40 & 81.50 & 82.00 \\
\hline 1981 & 0.91 & 91.57 & 98.07 & 89.20 & 85.90 \\
\hline 1982 & 0.97 & 96.88 & 98.73 & 96.00 & 91.40 \\
\hline 1983 & 1.00 & 99.90 & 99.40 & 100.30 & 100.40 \\
\hline 1984 & 1.04 & 102.60 & 97.40 & 103.80 & 108.20 \\
\hline 1985 & 1.08 & 106.10 & 98.70 & 106.80 & 119.20 \\
\hline 1986 & 1.10 & 110.60 & 77.10 & 110.30 & 135.00 \\
\hline 1987 & 1.14 & 114.40 & 80.20 & 114.80 & 146.20 \\
\hline 1988 & 1.18 & 116.50 & 80.90 & 119.70 & 156.60 \\
\hline 1989 & 1.24 & 119.20 & 88.50 & 124.90 & 166.60 \\
\hline 1990 & 1.31 & 121.40 & 101.20 & 130.10 & 177.90 \\
\hline 1991 & 1.36 & 126.60 & 105.54 & 135.67 & 185.52 \\
\hline 1992 & 1.41 & 130.69 & 108.94 & 140.05 & 191.51 \\
\hline 1993 & 1.46 & 135.43 & 112.89 & 145.13 & 198.45 \\
\hline 1994 & 1.51 & 140.26 & 116.92 & 150.31 & 205.53 \\
\hline 1995 & 1.56 & 144.90 & 120.79 & 155.28 & 212.34 \\
\hline 1996 & 1.61 & 149.92 & 124.97 & 160.66 & 219.69 \\
\hline 1997 & 1.68 & 155.58 & 129.69 & 166.73 & 227.99 \\
\hline 1998 & 1.74 & 161.53 & 134.65 & 173.10 & 236.70 \\
\hline 1999 & 1.81 & 168.03 & 140.07 & 180.07 & 246.23 \\
\hline 2000 & 1.89 & 175.09 & 145.95 & 187.63 & 256.57 \\
\hline
\end{tabular}

Note: Data beyond 1990 is based on CPI projection from DOEJEIA. 
EDS 2 is contained in the Basic Vehicle Module (Model page BASICVEH).

EDS 2 - Vehicle Curb Weight

\begin{tabular}{|c|l|c|c|c|}
\hline \multicolumn{5}{|c|}{$\begin{array}{c}\text { Curb Weight (kg) } \\
\text { Battery Perfromance Category } \\
\text { Low }\end{array}$} \\
\hline 1 & Conventional Auto & 1,178 & Medium & High \\
\hline 2 & & & & NA \\
\hline 3 & Conventional Van & 1,461 & NA & NA \\
\hline 4 & Electric Auto & 1,700 & 1,600 & 1,500 \\
\hline 5 & Electric Van & 1,800 & 1,700 & 1,600 \\
\hline 6 & Fuel Cell/Battery Auto & 1,656 & 1,548 & 1,472 \\
\hline 7 & & & & \\
\hline 8 & Fuel Cell/Battery Van & 2,070 & 1,921 & 1,816 \\
\hline
\end{tabular}


EDS 3 is contained in the Power Systems Module (Model page POWERSYS).

EDS 3 - Electric Drive Systems

\begin{tabular}{|c|c|c|c|c|}
\hline Type & Name & $\begin{array}{c}\text { Motor } \\
\text { Cost Factor }\end{array}$ & $\begin{array}{l}\text { Controller } \\
\text { Cost Factor }\end{array}$ & $\begin{array}{c}\text { Data } \\
\text { Vintage }\end{array}$ \\
\hline 0 & None & $\overline{0}$ & 0 & 1982 \\
\hline 1 & $A C$ & 19 & 45 & 1982 \\
\hline 2 & DC Brushless & 26.5 & 90 & 1982 \\
\hline 3 & $\overline{D C}$ Brush & 79 & 62.5 & 1982 \\
\hline
\end{tabular}


EDS 4 is contained in the Power Systems Module (Model page POWERSYS).

EDS 4 - ICE Drive Systems

\begin{tabular}{|c|c|c|c|}
\hline Type & Name & $\begin{array}{c}\text { Engine } \\
\text { Cost Factor }\end{array}$ & $\begin{array}{c}\text { Data } \\
\text { Vintage }\end{array}$ \\
\hline 0 & None & 0 & 1982 \\
\hline 1 & Gasoline & 360 & 1982 \\
\hline 2 & Diesel & 390 & 1982 \\
\hline
\end{tabular}


EDS 5 is contained in the Fuel Cell Module (Model page FUELCELL).

EDS 5 - Fuel Cell Performance \& Cogt Factors

\begin{tabular}{|c|c|c|c|c|c|c|c|c|c|}
\hline$\frac{T y x}{0}$ & Neme & $\begin{array}{c}\text { Speotifio power } \\
\text { Con innoure } \\
\text { Wikg) }\end{array}$ & $\begin{array}{c}\text { Pouk } \\
\text { Wurkgl }\end{array}$ & $\begin{array}{c}\text { Powor Densily } \\
\text { Conthuouse } \\
\text { (Wn) }\end{array}$ & $\begin{array}{l}\text { Peok } \\
\text { (wMIn }\end{array}$ & $\begin{array}{c}\text { Enoteney } \\
{[6]}\end{array}$ & $\begin{array}{c}\cos x \\
\cos x\end{array}$ & 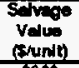 & 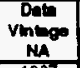 \\
\hline & $\begin{array}{l}\text { Phosphosicadid } \\
\text { PEM-Methend }\end{array}$ & $\frac{91}{100}$ & $\frac{250}{300}$ & $\frac{59}{98}$ & $\frac{179}{200}$ & $55 \%$ & $\frac{\$ 250}{\$ 165}$ & $\frac{5960}{5960}$ & \begin{tabular}{|l}
1987 \\
1987 \\
\end{tabular} \\
\hline 3 & PEM-Hytrogen & 230 & 465 & 340 & 688 & $53 \%$ & $\$ 180$ & $\frac{+500}{5800}$ & 1990 \\
\hline
\end{tabular}


EDS 6 is contained in the Battery Module (Model page BATTERY).

EDS 6 - Battery Performance \& Cost Factors

\begin{tabular}{|c|c|c|c|c|c|c|c|c|c|c|c|c|c|}
\hline Type & Nama & $\begin{array}{c}\text { Specitic Energy } \\
\text { (whkg) } \\
\text { Low }\end{array}$ & thigh & $\begin{array}{l}\text { Specific power } \\
\text { W/kg) } \\
\text { Low }\end{array}$ & High & $\begin{array}{c}\text { Effidonoy } \\
(\%)\end{array}$ & $\begin{array}{c}\text { Cycto } \\
\text { Lite }\end{array}$ & $\stackrel{A}{A}$ & $\underset{(s / \mathrm{km})}{8}$ & $\begin{array}{l}\text { द } \\
\text { (s) }\end{array}$ & $\begin{array}{c}\text { Salvage Valuo } \\
\text { (sikWh) } \\
\text { (1982 s) }\end{array}$ & $\begin{array}{c}\text { Rerative } \\
\text { Meinternanos } \\
\text { Fector }\end{array}$ & $\begin{array}{l}\text { Oatu } \\
\text { Vintege } \\
\end{array}$ \\
\hline$A$ & Low Portorm ance & 38 & 45 & 80 & 100 & $70 \%$ & 800 & 350 & 50 & 50 & $\$ 1.85$ & 2.00 & \begin{tabular}{|l|}
1985 \\
190
\end{tabular} \\
\hline $\mathrm{B}$ & Medium Performanca & 80 & 100 & 150 & 200 & $75 \%$ & 600 & 5150 & $\$ 0$ & 50 & $\$ 2.03$ & $\frac{1.00}{1.00}$ & $\frac{1990}{1920}$ \\
\hline$c$ & High Peflormancos & $\frac{200}{158}$ & \begin{tabular}{|l}
200 \\
158 \\
\end{tabular} & $\frac{400}{157}$ & 400 & $\frac{80 \%}{10 \%}$ & 1000 & $\$ 100$ & 50 & $\frac{\$ 0}{\$ 0}$ & 51.35 & $\frac{1.00}{6.50}$ & $\frac{1990}{1882}$ \\
\hline 2 & $\begin{array}{l}\text { A Aluminum-Alr } \\
\text { Bipolar }\end{array}$ & $\frac{158}{45}$ & \begin{tabular}{|l}
158 \\
56 \\
\end{tabular} & $\frac{157}{275}$ & $\frac{157}{600}$ & $\frac{18 \%}{85 \%}$ & $\frac{5000}{750}$ & $\frac{50}{572}$ & $\frac{542}{50}$ & $\frac{50}{50}$ & $\frac{50.00}{\$ 1.85}$ & $\frac{4.50}{100}$ & $\frac{188}{188}$ \\
\hline 3 & Iron-Air & 55 & 100 & $\frac{1}{102}$ & 146 & $50 \%$ & 500 & 591 & $\frac{0}{50}$ & 50 & $\$ 0.00$ & $\frac{1.00}{4.00}$ & $\frac{198}{198}$ \\
\hline 4 & Load-Acid & 38 & 45 & 80 & 100 & 7070 & 800 & $\$ 50$ & so & $\$ 0$ & $\$ 1.85$ & 2.00 & \\
\hline 5 & |lithium-Iron & 72 & 102 & 90 & 107 & $60 \%$ & 750 & 881 & so & so & $\$ 2.23$ & 2.50 & 188. \\
\hline 6 & Nickel-Fon & 48 & 56 & 75 & 110 & $58 \%$ & 1500 & 5125 & so & 50 & 87.31 & 2.50 & $\frac{1985}{1985}$ \\
\hline & Nikeketzinc & & 60 & 155 & 155 & $70 \%$ & 600 & 564 & \$0 & 50 & $\$ 11.41$ & 1.50 & $\frac{1985}{1095}$ \\
\hline 8 & Sodium-Sulfur & 75 & 130 & 130 & 210 & $80 \%$ & 750 & 591 & so & $\$ 0$ & 80.00 & 4.50 & $\frac{1985}{1095}$ \\
\hline$\frac{9}{10}$ & ZZno-Bromine & $\frac{40}{42}$ & \begin{tabular}{|l}
75 \\
75 \\
\end{tabular} & $\frac{52}{80}$ & $\frac{94}{115}$ & $\frac{60 \%}{48 \%}$ & $\frac{600}{1250}$ & $\frac{\$ 75}{575}$ & $\frac{50}{50}$ & $\frac{50}{50}$ & $\frac{\$ 2.23}{\$ 0.00}$ & $\frac{4.00}{4.00}$ & \begin{tabular}{|l}
1985 \\
1985 \\
\end{tabular} \\
\hline
\end{tabular}


EDS 7 is contained in the Operating Cost Module (Model page OPCOST).

EDS 7 - Power System Maintenance Factors

\begin{tabular}{|c|c|c|}
\hline Data Vintage & Power System & $\begin{array}{l}1982 \\
\text { Factor }\end{array}$ \\
\hline 1 & TICE & 1.675 \\
\hline 2 & Fuel Cell/Battery & 2.250 \\
\hline 3 & Battery EV & 1.750 \\
\hline
\end{tabular}


EDS 8 is contained in the Operating Cost Module (Model page OPCOST).

EDS 8 - Vehicle Maintenance Factors

\begin{tabular}{|c|c|c|c|}
\hline Data Vintage & & & 1982 \\
\hline Type & Type of Vehicle & Vehicle Factors & \\
\hline 1 & Conventional Auto & 0.0123 & 78.67 \\
\hline 2 & Conventional Bus & 0.0200 & 150.00 \\
\hline 3 & Conventional Van & 0.0191 & 81.73 \\
\hline 4 & Electric Auto & 0.0114 & 81.73 \\
\hline 5 & Electric Van & 0.0114 & 81.73 \\
\hline 6 & Fuel Cell/Battery Auto & 0.0037 & 90.00 \\
\hline 7 & Fuel Cell/Battery Bus & 0.0060 & 160.00 \\
\hline 8 & Fuel Cell/Battery Van & 0.0057 & 85.00 \\
\hline
\end{tabular}


EDS 9 is contained in the Operating Cost Module (Model page OPCOST).

\section{EDS 9 - Insurance Factors}

\begin{tabular}{|c|c|c|}
\hline \begin{tabular}{|l} 
Data Vintage \\
Passengers
\end{tabular} & & $\begin{array}{c}1982 \\
\text { Passenger Factors }\end{array}$ \\
\hline 2 & 748 & 243 \\
\hline 4 & 748 & 243 \\
\hline 5 & 919 & 256 \\
\hline 6 & 748 & 243 \\
\hline $10+$ (Buses) & 1500 & 260 \\
\hline
\end{tabular}


EDS 10 is contained in the Environmental Cost Module (Model page ENVIRO).

EDS 10 - Emissions Cost

\begin{tabular}{|l|c|c|r|}
\hline \multicolumn{4}{|c|}{$\begin{array}{c}1990 \\
(\$ \text { per ton })\end{array}$} \\
\hline Hydrocarbons (HC) & & $\$ 10,000$ & 1990 \\
\hline Carbon Monoxide (CO) & & $\$ 850$ & 1990 \\
\hline Nitrogen Oxides (NOx) & & $\$ 5,000$ & 1990 \\
\hline
\end{tabular}

EDS 10 - Emissions Cost (continued)

\begin{tabular}{|c|c|c|c|c|c|}
\hline & Partic & $\mathrm{SO} 2$ & $\begin{array}{l}\text { I\$ per unit } \\
\text { Aldehyde }\end{array}$ & BTX & $\mathrm{CO} 2 \mathrm{EQ}$ \\
\hline Unit & TON & TON & TON & TON & TON \\
\hline Value & 4500 & 450 & 2000 & 2000 & 16 \\
\hline Year & 1990 & 1990 & 1990 & 1990 & 1990 \\
\hline
\end{tabular}


EDS 11 is contained in the Environmental Cost Module (Model page ENVIRO).

EDS 11 - Emissions Allocation

\begin{tabular}{|c|c|c|c|c|}
\hline $\begin{array}{l}\text { Fuel } \\
\text { Type }\end{array}$ & Vehicle & \multicolumn{3}{|c|}{ (gm per km) } \\
\hline 1 & Gasoline ICE & 0.440 & 3.800 & 0.280 \\
\hline 2 & Diesel & 0.130 & 0.470 & 1.260 \\
\hline 3 & Methanol ICE (M100) & 0.580 & 1.060 & 0.380 \\
\hline 4 & Ethanol (E100) ICE & 0.240 & 1.060 & 0.120 \\
\hline 5 & Methane (CNG) ICE & 0.120 & 0.080 & 0.360 \\
\hline 6 & Gasoline ICE 2003 Limit & 0.400 & 3.420 & 0.280 \\
\hline 7 & Reformulated diesel & 0.030 & 0.130 & 1.220 \\
\hline 8 & M85 ICE & 0.559 & 1.471 & 0.365 \\
\hline 9 & Fuel Cell/Hydrogen & 0.000 & 0.000 & 0.000 \\
\hline 10 & 1992 Limit & 0.156 & 2.125 & 0.250 \\
\hline 11 & Fuel Cell/Methanol & 0.050 & 0.080 & 0.480 \\
\hline 12 & Elec & 0.020 & 0.040 & 0.120 \\
\hline
\end{tabular}

EDS 11 - Emissions Allocation (continued)

\begin{tabular}{|c|c|c|c|c|c|}
\hline \multicolumn{3}{|l|}{ Fuel } & \multicolumn{3}{|c|}{ [Gm per $\mathrm{Km}]$} \\
\hline Type & Partic & $\mathrm{SO} 2$ & Aldehyde & BTX & $\mathrm{CO} 2 \mathrm{EQ}$ \\
\hline 1 & 0.0100 & 0.0350 & 0.0030 & 0.0450 & 260 \\
\hline 2 & 0.0733 & 0.0000 & 0.0000 & 0.0000 & 210 \\
\hline$\overline{3}$ & 0.0000 & 0.0000 & 0.0080 & 0.0100 & 84 \\
\hline$\overline{4}$ & 0.0000 & 0.0020 & 0.0180 & 0.0090 & 82 \\
\hline 5 & 0.0028 & 0.0000 & 0.0065 & 0.0000 & 231 \\
\hline 6 & 0.0100 & 0.0350 & 0.0030 & 0.0450 & 263 \\
\hline 7 & 0.0536 & 0.0000 & 0.0000 & 0.0000 & 210 \\
\hline 8 & 0.0015 & 0.0053 & 0.0073 & 0.0153 & 111 \\
\hline 9 & 0.0000 & 0.0000 & 0.0000 & 0.0000 & 77 \\
\hline 10 & & & & & \\
\hline 11 & 0.0000 & 0.0000 & 0.0080 & 0.0100 & 84 \\
\hline 12 & 0.0000 & 0.1500 & 0.0000 & 0.0000 & 244 \\
\hline
\end{tabular}


EDS 12 is contained in the Energy Cost Module (Model page ENERGY).

EDS 12 - Fuel Prices

\begin{tabular}{|c|c|c|c|c|c|c|c|c|}
\hline Type & & $\begin{array}{c}\text { Volumetric } \\
\text { Density } \\
\text { kg/l }\end{array}$ & $\begin{array}{c}\text { Energy } \\
\text { Density } \\
\text { BTU/1 }\end{array}$ & $\begin{array}{l}\text { Energy } \\
\text { Equivalent } \\
s \|\end{array}$ & $\$$ \$gal & $\begin{array}{l}\text { Estimated } \\
\text { Commercialized } \\
\$ \wedge\end{array}$ & $\$ / g a l$ & $\begin{array}{l}\text { Data } \\
\text { Year } \\
\text { Basis }\end{array}$ \\
\hline 1 & Gasoline & 0.737 & 30,154 & $\$ 0.28$ & $\$ 1.34$ & $\$ 0.35$ & $\$ 1.34$ & 1990 \\
\hline 2 & Diesel & 0.827 & 34,188 & $\$ 0.29$ & $\$ 1.38$ & $\$ 0.36$ & $\$ 1.38$ & 1990 \\
\hline 3 & Methanol (M100) & 0.791 & 14,943 & $\$ 0.14$ & $\$ 0.53$ & $\$ 0.23$ & $\$ 0.89$ & 1990 \\
\hline 4 & Ethanol (E100) & 0.791 & 19,992 & $\$ 0.19$ & $\$ 0.71$ & $\$ 0.39$ & $\$ 1.48$ & 1990 \\
\hline 5 & Methane (CNG) & 0.161 & 6,526 & $\$ 0.06$ & $\$ 0.23$ & $\$ 0.07$ & $\$ 0.26$ & 1990 \\
\hline 6 & Reformulated Gasoline & 0.731 & 29,824 & $\$ 0.28$ & $\$ 1.33$ & $\$ 0.39$ & $\$ 1.46$ & 1990 \\
\hline 7 & Reformulated Diesel & 0.827 & 34,188 & $\$ 0.29$ & $\$ 1.10$ & $\$ 0.32$ & $\$ 1.20$ & 1990 \\
\hline 8 & M85 & 0.783 & 17,225 & $\$ 0.16$ & $\$ 0.61$ & $\$ 0.25$ & $\$ 0.96$ & 1990 \\
\hline 9 & Hydrogen @8000 psi & 0.023 & 3,056 & $\$ 0.03$ & $\$ 0.11$ & $\$ 0.78$ & $\$ 2.97$ & 2000 \\
\hline
\end{tabular}

@3000 psig 
EDS 13 is contained in the Energy Cost Module (Model page ENERGY).

\section{EDS 13 - Import Premium}

Import Premium
$\$ 0.275 \quad \$ / G A L$


EDS 14 is contained in the Hydrogen PEM Module (Model page HEPEM).

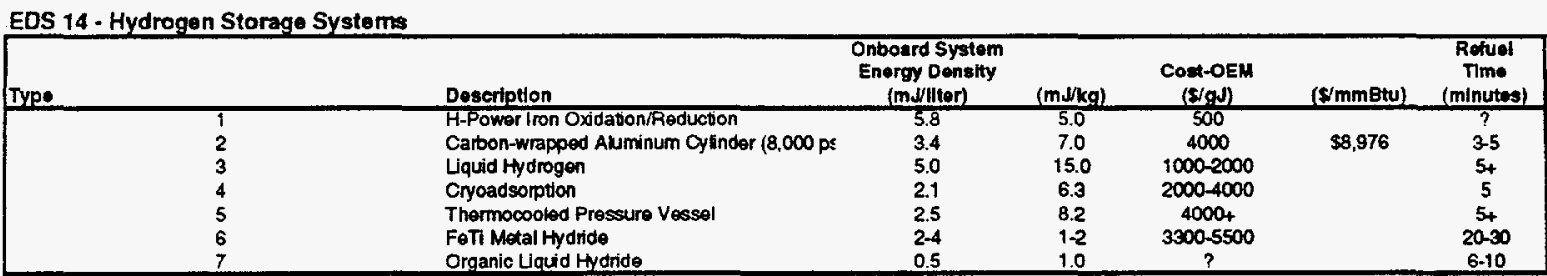

Re1 52: Deilucchi, Table 3, p. 59 . 
EDS 15 is contained in the Hydrogen PEM Module (Model page HEPEM).

EDS 15 - Hydrogen Fuel Cost in 2000

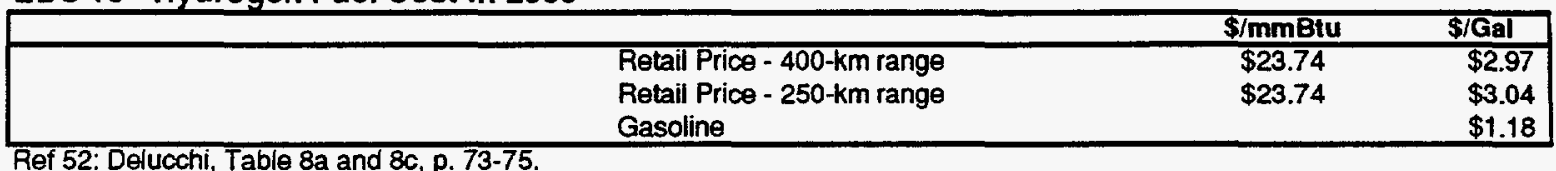


EDS 16 is contained in the Hydrogen PEM Module (Model page HEPEM).

EDS 16 - Pertormance of Hydrogen PEM Fuel Cells

\begin{tabular}{|c|c|c|c|c|c|c|c|}
\hline & $\begin{array}{c}\text { Specific Power } \\
\text { W/kg } \\
\text { Continuous }\end{array}$ & Peak & $\begin{array}{c}\text { Power Density } \\
\text { Wn } \\
\text { Continuous }\end{array}$ & Peak & $\begin{array}{c}\text { Efficiency } \\
(\%)\end{array}$ & $\begin{array}{l}\text { Cost } \\
1990 \$ \\
(\$ / K w)\end{array}$ & $\begin{array}{l}\text { Salvage } \\
\text { Value } \\
\text { (S/unit) }\end{array}$ \\
\hline PEM@ $3.4 \mathrm{~atm}$ pressure & 230 & 465 & 340 & 688 & $53.26 \%$ & $\$ 180$ & $\$ 960$ \\
\hline
\end{tabular}




\section{APPENDIX D - REFERENCE CASE ANALYSIS RESULTS}

The following fourteen cases were analyzed for this work:

Case 1A Reference Car - Conventional Gasoline/Automatic Transmission

Case 1B Reference Car - Conventional Gasoline/Manual Transmission

Case 2A Reference Van - Conventional Gasoline/Automatic Transmission

Case 2B Reference Van - Conventional Gasoline/Manual Transmission

Case 3A Reference Car - Conventional Diesel/Automatic Transmission

Case 3B Reference Car - Methanol M-100/Automatic Transmission

Case 3C Reference Car - Ethanol E-100/Automatic Transmission

Case 3D Reference Car - Compressed Natural Gas/Automatic Transmission

Case 3E Reference Car - Reformulated Gasoline/Automatic Transmission

Case 3F Reference Car - Reformulated Diesel/Automatic Transmission

Case 3G Reference Car - Methanol Blend M-85/Automatic Transmission

Case 4A Reference Electric Car - High Technology Lead-Acid Battery/DC Brushless Motor/Automatic Transmission

Case 5A Reference Fuel Cell/Battery Car - Methanol M-100/PEMFC/Medium Perfromance Genreic Battery/DC Brushless Motor/Automatic Transmission

Case 5B Reference Fuel Cell/Battery Car - Hydrogen/PEMFC/Medium Perfromance Genreic Battery/DC Brushless Motor/Automatic Transmission 


\section{LIFE CYCLE COST MODEL INPUT MODULE}

Case Number:

Basic Vehicle Configuration

Technology Options

Type of Vehicle

Power System

Type of ICE

Type of Fuel Cell

Type of Fuel

Type of Battery Propulsion

Type of Motor/Controller

Type of Transmission

Status of Technology

\begin{tabular}{|c|}
\hline Input \\
\hline 1 \\
\hline 1 \\
\hline 1 \\
\hline 0 \\
\hline 1 \\
\hline 0 \\
\hline 0 \\
\hline 1 \\
\hline Low \\
\hline
\end{tabular}

Option:

A

Conventional Auto

ICE

Spark Ignition

None

Conventional Gasoline

None

None

Automatic

Low

Options
$1-8$
$1-3$
$0-2$
$0-2$
$0-8$
$0, A-C: 1-10$
$0-3$
$1-2$
Low/High

Vehicle Physical Characteristics

Conventional Auto

Passonger Capacity $(2,4,5,6+, 10+)$

Test Weight (kg)

Curb Woight $(\mathrm{kg})$

Base Vehicle Weight $(\mathrm{kg})$

Accessories $(\mathrm{kg})$

Vehide Frontal Area (sq. m)

Basic Material Salvage Value $(\$ / \mathrm{kg})$

Lite of Vehicle (yr)

Distance Traveled (km/yr)

Life Cycle Distance Traveled $(\mathrm{km})$

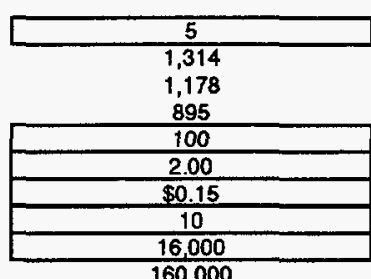

Vehiclo Performance Characteristics

Accoleration to $88 \mathrm{Km} / \mathrm{h}$ (s)

Top Speed (km/h)

Gradability (\%)

Rolling Friction Coefficient (km/km)

Aorodynamic Drag Coefficient

Peak Power: (kW)

Driving Schedule

Battery Power-to-Energy Ratio

Range (km)

Full Cycles per year

Partial Cycles per year

20
110
7

ropulsion System Characteristics Power Sysiem

ICE:

Engine Power ( $k W$ )

Specific Power $(\mathrm{kW} / \mathrm{kg})$

Specific Cost $(\$ / \mathrm{kW})$

Engine Woight $(\mathrm{kg})$

Fuel Efficiency: (km/l) gasoline equiv (mpg)

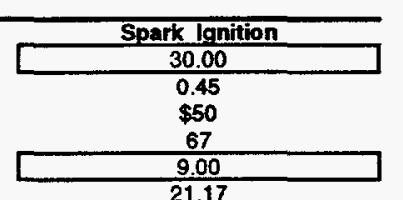

\section{Enorgy Source}

Conventional Gasoline

Fuel Cost (\$N)

Fuel Efficiency $(\mathrm{Vkm})$

Eledricity Cost (\$/kWhr)

Fuel Efficiency (kWhr/km)

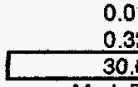

110

0.010

30.00

Mod. FUDS

NA
400

400
40

Drive Train

Whotor

Peak Power (kW)

Fuel Coll:

Specific Power [Continuous] (kW/kg)

Power Density [Continuous] (kW/I)

Efficiency

Specitic Cost $(\$ / k W)$

Woight (kg)

Fuel Efficiency: $(\mathrm{km} / \mathrm{l})$

$$
\text { (mpg) }
$$

\begin{tabular}{|c|}
\hline None \\
\hline 0.00 \\
\hline 0.000 \\
0.000 \\
$0 \%$ \\
$\$ 0$ \\
0 \\
\hline 12.00 \\
\hline 28.22 \\
\hline
\end{tabular}

Battery:

Power Rating (kW)

Energy Capacity ( $k W h$ )

Specific Energy (Wh/kg)

Specific Power (W/kg)

Efficiency $(\%)$

Cydo Life

Specific Cost $(\$ / \mathrm{kW})$

Waight (kg)

$80 \%$ Full Range Discharge $(\mathrm{km})$

Number of Replacements

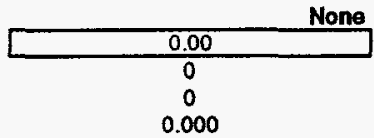

None

Specific Power $(\mathrm{kW} / \mathrm{kg})$

Weight $(\mathrm{kg})$

Controller

Peak Power ( $k W$ )

Specific Power (kW/kg)

Weight (kg)

Transmission System

Paak Power (kW)

Specific Power ( $k W / k g)$

Weight (kg)

Drivo Train Efficioncy (\%)

$\$ 0.38$

0.11

$\$ 0.05$

conomic Analysis Factors

Analysis base year

Present Value Discount Rate (\%100)

Cost Escalation[ilnflation] Rate $(\% / 100)$

\begin{tabular}{|c|}
\hline 1992 \\
\hline 0.080 \\
\hline 0.045 \\
\hline
\end{tabular}

Fuel Tank

Material

Specific Weight (gm/cc)

Specific Cost $(\$ / k g)$

Tank Capacity: (I)

Tank Weight (w/ Fuel) (kg)

None

0.00

None

0.00

Cost of Capital $(\% / 100)$

Loan Term (yr)

Down payment $(\%)$

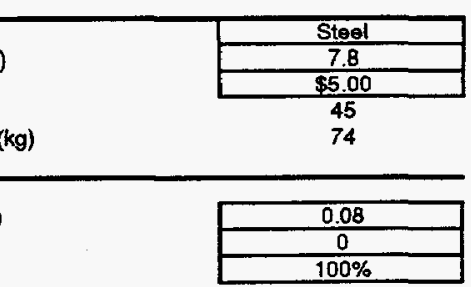

End of Input Soction 


\section{Life Cycle Cost Summary}

1992

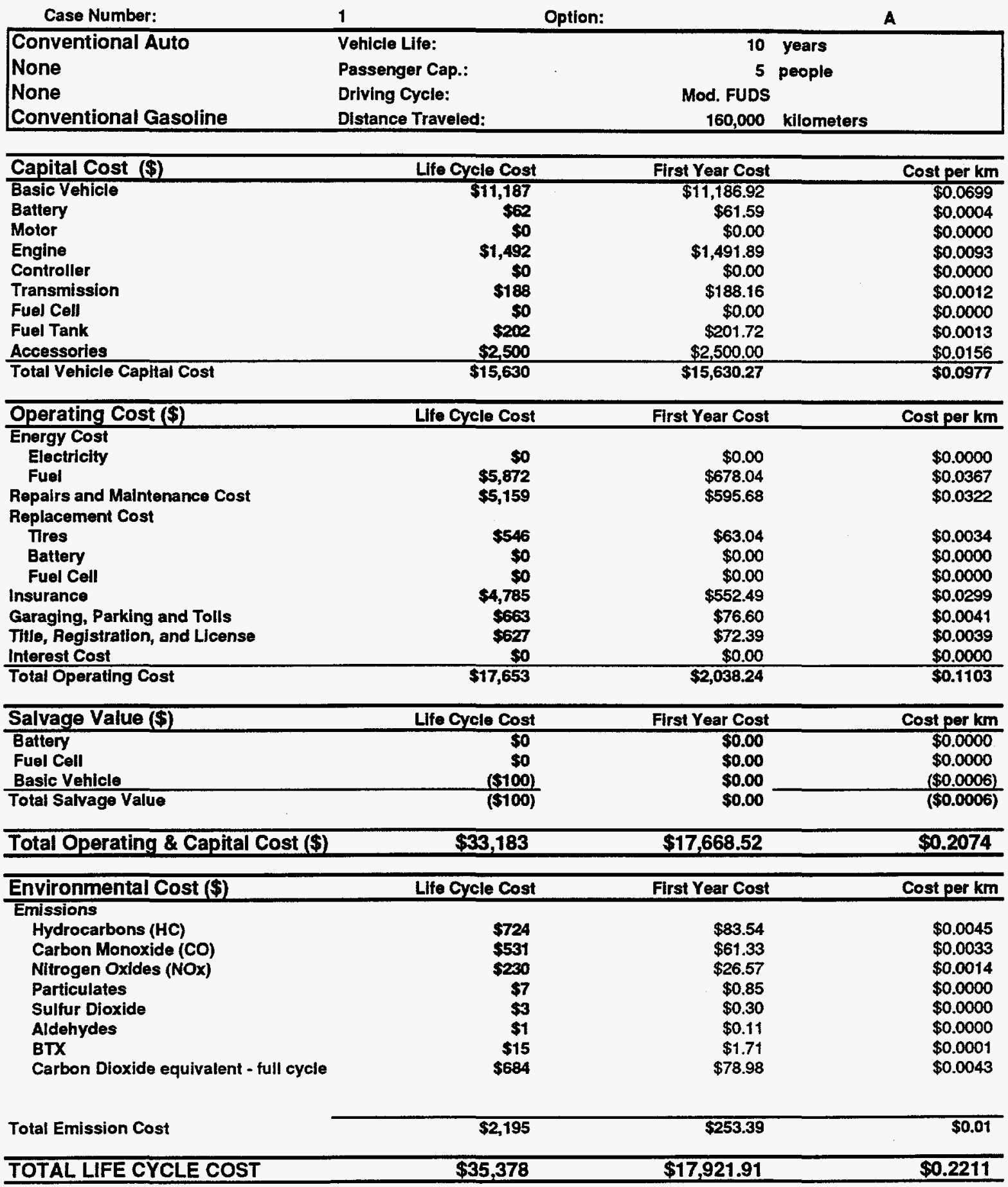




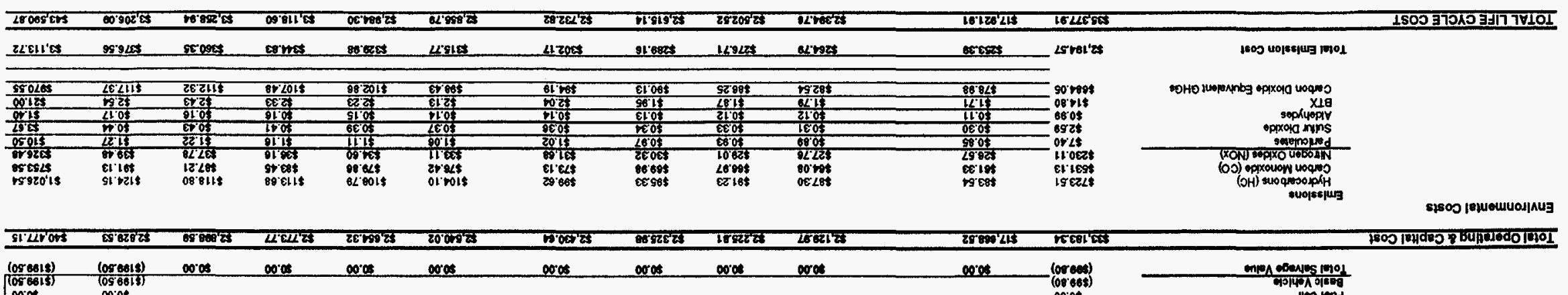

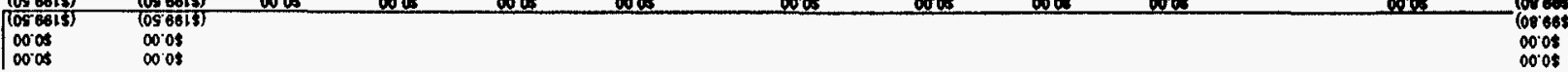

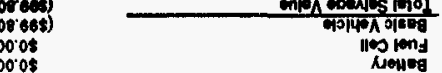

ONION OBENIES

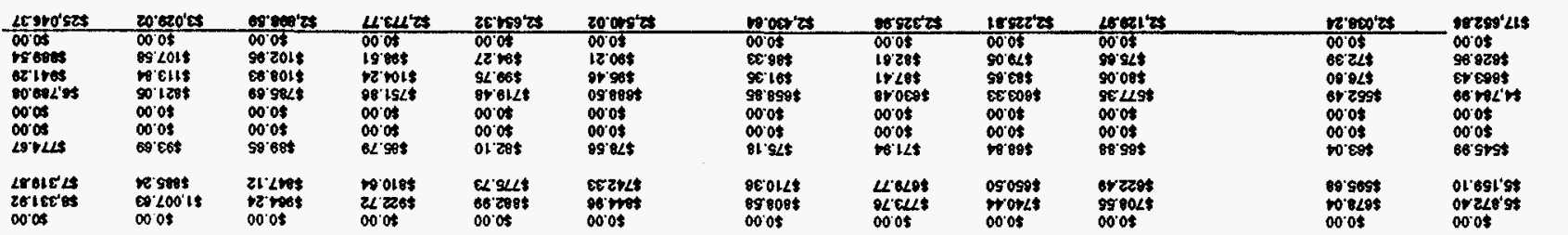

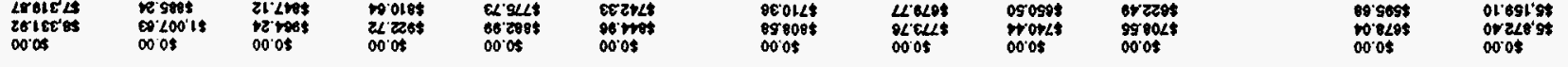

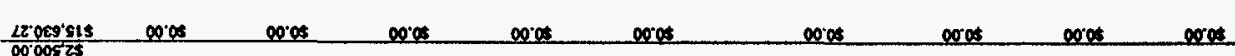
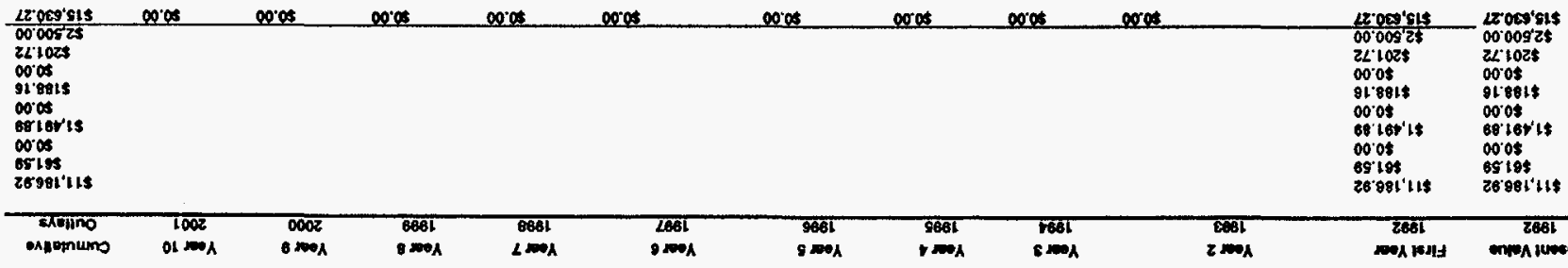

26981 '1

oxponums ot

$080^{\circ} 0$
$080^{\circ} 0$ sont

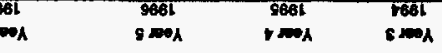

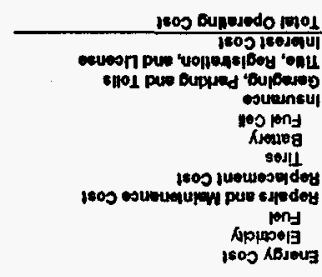

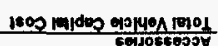

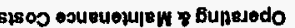

\begin{tabular}{|c|}
\hline 0800 \\
\hline
\end{tabular}

:

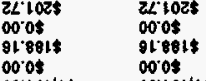

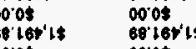

0006

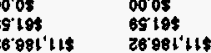

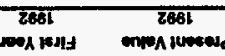

S500

ixphes

insondasi

ouon

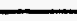

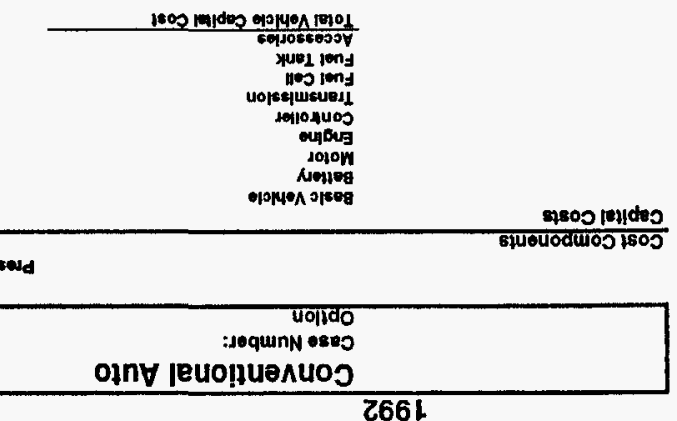




\section{LIFE CYCLE COST MODEL INPUT MODULE}

Case Number:

1

Option:

$\mathbf{8}$

Basic Vehicle Contiguration

\begin{tabular}{l|l|}
\hline Technology Options \\
Type of Vehicle \\
Power System \\
Type of ICE \\
Type of Fuet Cell \\
Type of Fuel \\
Type of Battery Propulsion \\
Type of Motor/Controller \\
Type of Transmission \\
Status of Technology
\end{tabular}

Conventional Auto
ICE
Spark Ignition
None
Conventional Gasoline
None
None
Manual
Low

Options

$1-8$

$1-3$

$0-2$

$0-2$

$0-8$

$0, A-C: 1-10$

$0-3$

ow/High

Vehicle Physical Characteriotics

Conventional Auto

Passenger Capacity $(2,4,5,6+10+)$

Test Woight $(\mathrm{kg})$

Curb Weight $(\mathrm{kg})$

Base Vehiclo Weight $(\mathrm{kg})$

Accessories (kg)

Vehicle Frontal Area (sq. m)

Basic Material Salvage Value (\$\$kg)

Life of Vehicle (yr)

Distance Traveled (km/yr)

Life Cycle Distance Traveled (km)

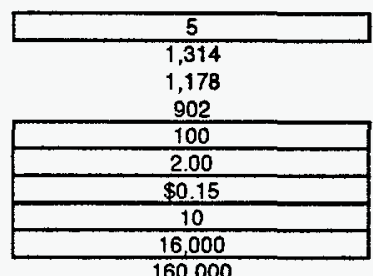

Vehicle Perfomance Characteriatica

Accoleration to B8Km/ (s)

Acceleration to $88 \mathrm{~K}$
Top Speed $(\mathrm{km} / \mathrm{h})$

Gradability (\%)

Rolling Friction Coefficient (km/km)

Aerodynamic Drag Coefficient

Peak Power: (kW)

Driving Schedule

Battery Power-10-Energy Ratio

Range (km)

Full Cycles per year

Partial Cycles per year

20

roputsion System Characteristics Power System

ICE:

Engine Power (kW)

Specific Power (kW/kg)

Specific Cost (\$/kW)

Engine Weight $(\mathrm{kg})$

Fuel Efficiency: (km/) gasoline equiv (mpg)

Fuel Cell:

Power Rating (kW)

Specific Power [Continuous] (kW/kg)

Power Density [Continuous] (kW/)

Efficiency

Specitic Cost (\$/kW)

Weight $(\mathrm{kg})$

Fuel Efficiency: (km/)

(mpg)

Battery:

Power Rating (kW)

Energy Capacity (kWh)

Specitic Energy (Wh/kg)

Specilic Power (W/kg)

Efficiency $(\%)$

Cycte Lifo

Specitic Cost (\$/kW)

Weight (kg)

$80 \%$ Full Range Discharge (km)

Number of Replacements

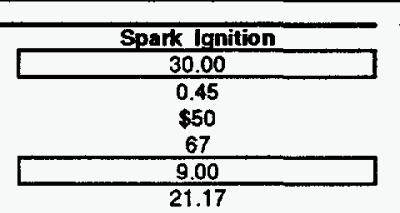

Energy Source

Conventional Gasoline

Fuel Cost (\$I)

Fuel Efficiency $(V \mathbf{k m})$

Electricity Cost (S/kWhr)

Fuel Efficiency (kWhr/km)

Drive Train

Motor

\begin{tabular}{ll} 
None & $\begin{array}{l}\text { Peak Power }(\mathrm{kW}) \\
\text { Specitic Power (kW/kg) }\end{array}$ \\
\hline 0.00 &
\end{tabular}

Woight (kg)

10

7

0.010

0.000

0.000

$0 \%$

30.00

FUDS

Controller

Peak Power (kW)

Specific Power $(\mathrm{kW} / \mathrm{kg})$

Woight $(\mathrm{kg})$

NA
400

40

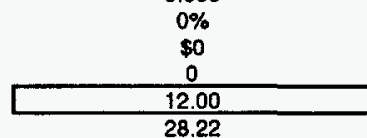

Transmisaion System

Peak Power (kW)

Specific Power (kW/kg)

Weight (kg)

Drive Train Efficiency (\%)

$\$ 0.38$

0.11

$\$ 0.05$

conomic Anatysis Factors

Analysis base year

Present Value Discount Rate (\%100)

Cost Escalationflnflation] Rate $(\% 100)$

\begin{tabular}{|c|}
\hline 1992 \\
\hline 0.080 \\
\hline 0.045 \\
\hline
\end{tabular}

Loan Term (yr)

Down payment $(\%)$

\section{Fuel Tank}

Material

Specitic Weight (gm/co)

Specific Cost (\$/kg)

Tank Capacity: (I)

Tank Woight (w/ Fuel) (kg)

None

None
0.00

0

Iona

0.00

nual

1.06

28

End of Ingut Section

Engineering Systems Management, Inc. 


\section{Life Cycle Cost Summary}

\section{2}

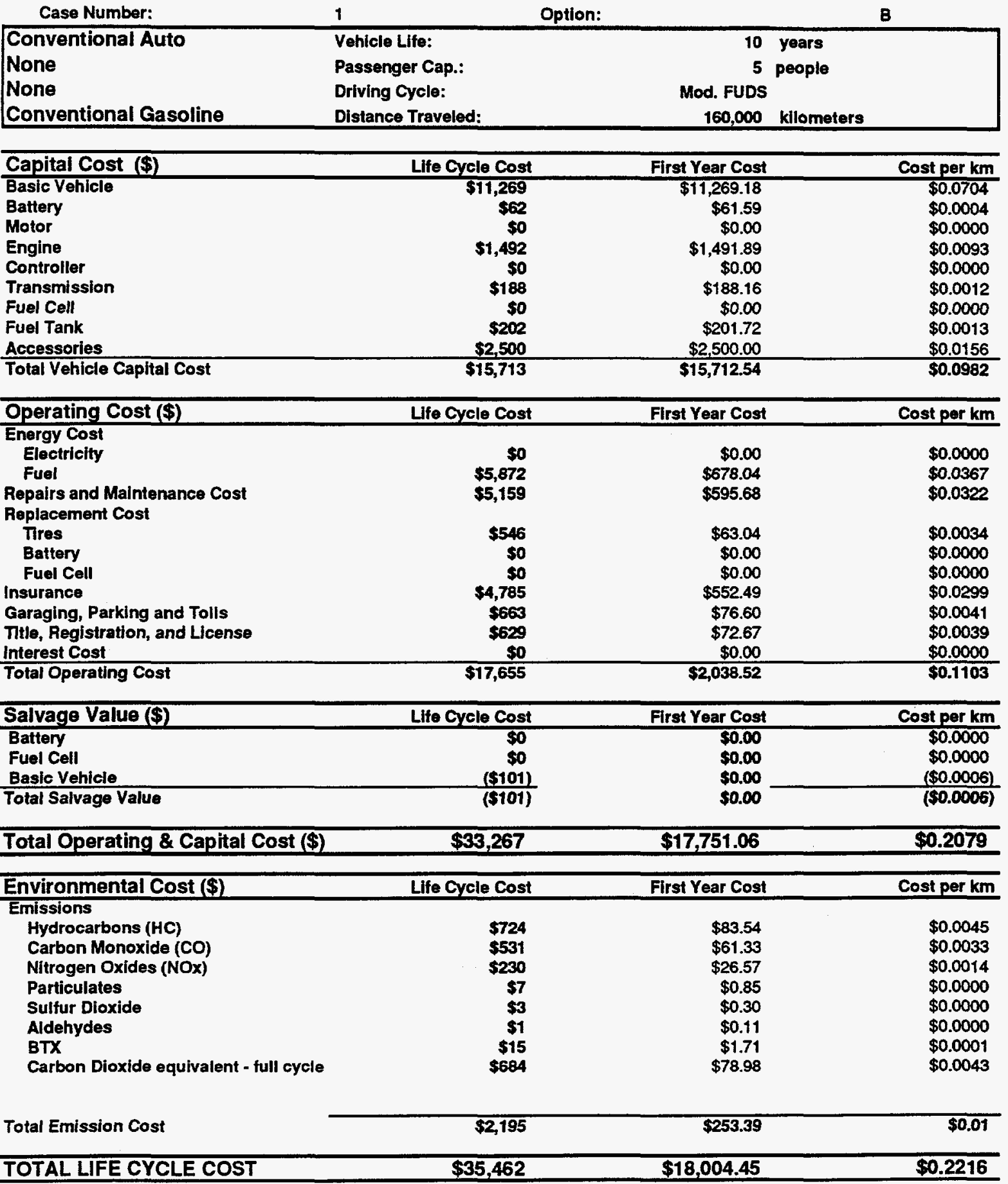




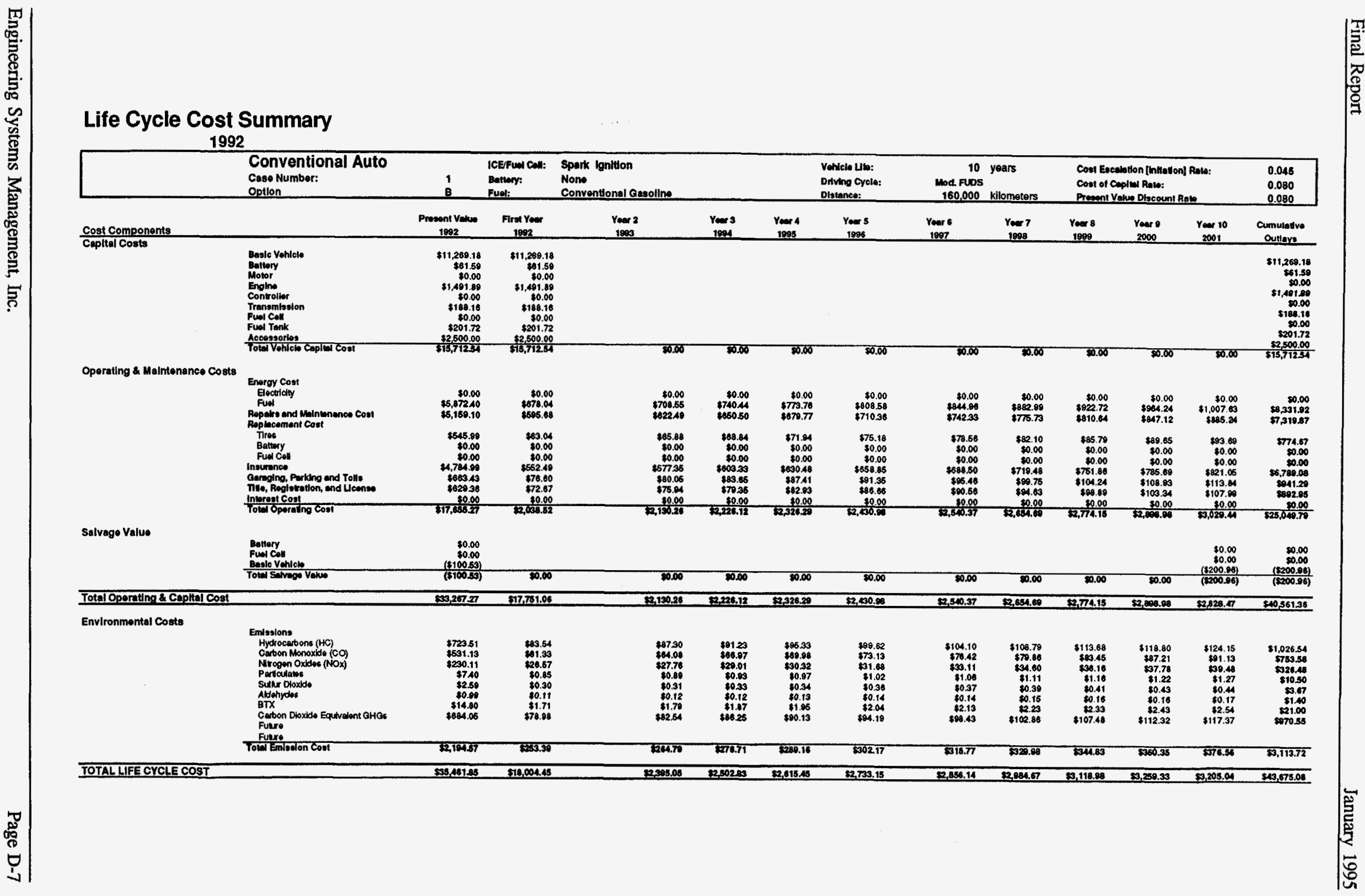




\section{LIFE CYCLE COST MODEL INPUT MODULE}

Case Number:

Basic Vehicie Configuration

Technology Options

Type of Vehicle

Power System

Typo of ICE

Type of Fuel Cell

Type of Fuel

Type of Battery Propulsion

Type of Motor/Controller

Type of Transmission

Status of Technology
2

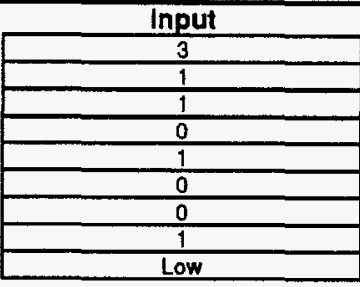

Option:

Conventional Van

ICE

Spark tgnition

None

Conventional Gasoline

None

None

Automatic

Low
A

Options

$1-8$

$1-3$

$0-2$

$0-8$

$0, A-C: 1-10$

0-3

Low/High

\begin{tabular}{l|l}
\hline Vehicle Physical Characteristics \\
\hline Conventional Van \\
Passenger Capacity $(2,4,5,6+, 10+)$ \\
Test Weight (kg) & 5 \\
Curb Weight (kg) & 1,756 \\
Base Vehicle Weight (kg) & 1,461 \\
Accessories (kg) & 1,141 \\
Vehicle Frontal Area (sq. m) & 100 \\
Basic Material Salvage Value (\$/kg) & 2.00 \\
Life of Vehicle (yr) & $\$ 0.15$ \\
Distance Traveled (km/yr) & 10 \\
Life Cycle Distance Traveled (km) & 16,000 \\
\hline
\end{tabular}

Vehicte Performance Characteristics

Accoleration to $88 \mathrm{Km} / \mathrm{h}$ (s)

Top Speed $(\mathrm{km} / \mathrm{h})$

Gradability (\%)

Rolling Friction Coefficient (km/km)

Aerodynamic Drag Coefficient

Peak Power: (kW)

Driving Scthedule

Battery Power-to-Energy Ratio

Range (km)

Full Cycles per year

Partial Cycles per year

\section{0}

110

0.470

40.86

Mod. FUDS

NA

400

40

355

Propulsion System Characteristics

Power System

ICE:

Engine Power (kW)

Specitic Power ( $k W / k g)$

Specific Cost (\$/kW)

Engine Weight (kg)

Fuel Efficiency: $(\mathrm{km} / \mathrm{l})$ gasoline equiv (mpg)

Fuel Cell:

Power Rating (kW)

Specific Power [Continuous] (kW/kg)

Power Density [Continuous] (kW/l)

Efficiency

Specific Cost $(\$ / \mathrm{kW})$

Woight (kg)

Fuel Efficiency: (km/l)

(mpg)

Battery:

Power Rating (kW)

Energy Capacity (kWh)

Specific Energy (Wh/kg)

Specific Power (W/kg)

Efficiency (\%)

Cycle Life

Specific Cost (\$/kW)

Weight (kg)

80\% Full Range Discharge (km)

Number of Replacements

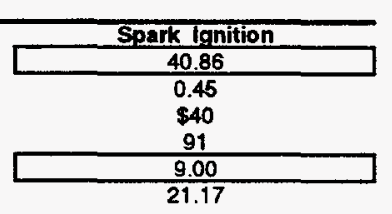

Energy Source

Conventional Gasoline

Fuel Cost (\$/l)

Fuel Efficiency $(\mathrm{Vkm})$

Electricity Cost ( $\$ / k W h r)$

Fuel Efficiency (kWhr/km)

Drive Train

Totor

Peak Power (kW)

Specific Power (kW/kg)

Woight $(\mathrm{kg})$

Controller

Peak Power (kW)

Specific Power (kW/kg)

Weight $(\mathrm{kg})$

Tranemiseion System

Peak Power (kW)

Specific Power (kW/kg)

Woight (kg)

Drive Train Efficiency (\%)

$\$ 0.38$

0.11

$\$ 0.05$

0.4

conomic Analysis Factors

Analysis base year

Present Value Discount Rate (\%100)

Cost Escalation[inflation] Rate (\%/100)

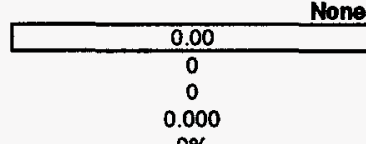

Fuel Tank

Materia

Specilic Weight (gm/cc)

Specitic Cost $(\$ / \mathrm{kg})$

Tank Capacity: (I)

Tank Weight (w/ Fuel) (kg)

None

0.00

0

0

None

0.00

0

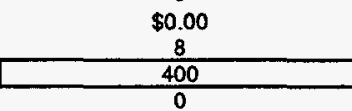

Cost of Capital (\%/100)

Loan Term (yr)

Down payment (\%)
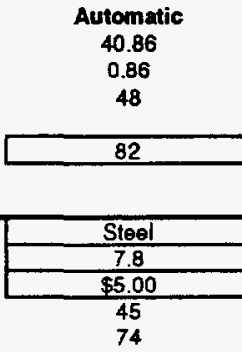

\begin{tabular}{|r|}
\hline 1992 \\
\hline 0.080 \\
\hline 0.045 \\
\hline
\end{tabular}

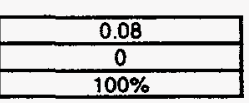

End of input Section 


\section{Life Cycle Cost Summary}

\section{2}

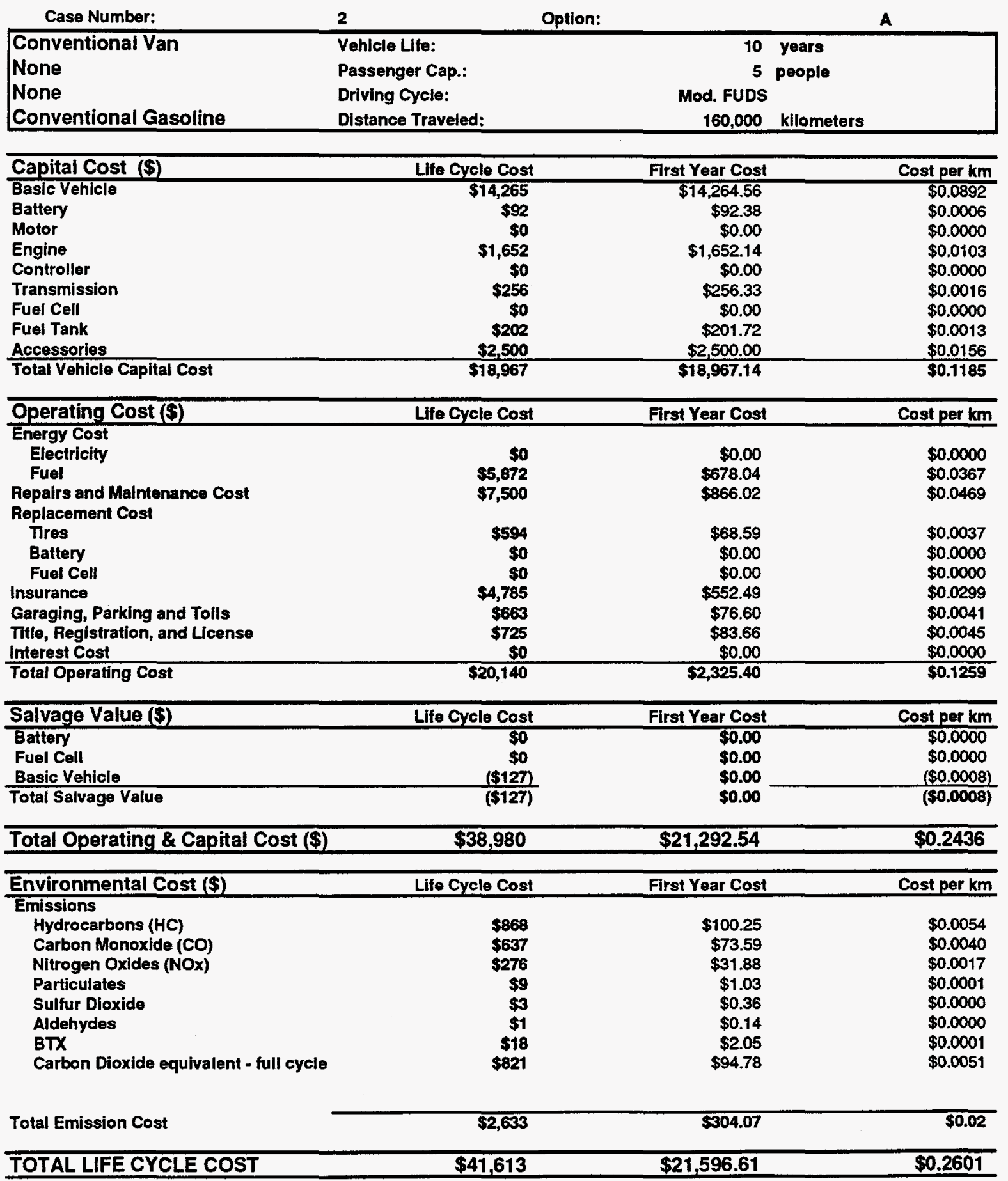




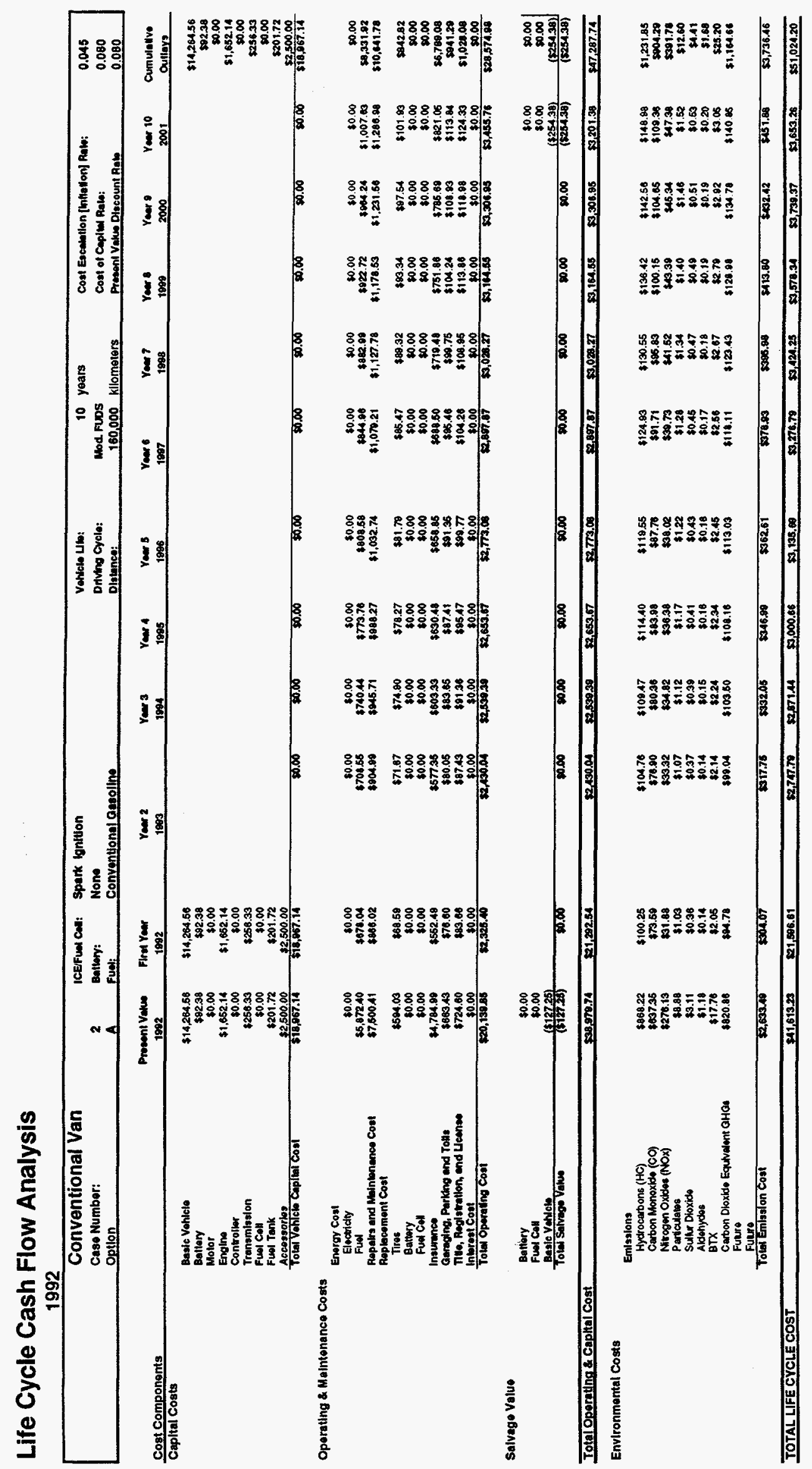




\section{LIFE CYCLE COST MODEL INPUT MODULE}

Case Number:

Option:

B

Basic Vehicle Configuration

\begin{tabular}{l|}
\hline Technology Options \\
Type of Vehicle \\
Power System \\
Type of ICE \\
Type of Fuel Cell \\
Type of Fuel \\
Type of Battery Propulsion \\
Type of Motor/Controller \\
Type of Transmission \\
Status of Technology
\end{tabular}

Conventional Van

ICE

Spark lgnition

None

Conventional Gasoline

None

None

Mamual

Low

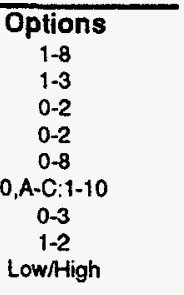
Vehicle Physical Characteristice
Conventional Van
Passenger Capacity $(2,4,5,6+, 10+)$
Test Woight ( $\mathrm{kg}$ )
Curb Woight $(\mathbf{k g})$
Base Vehiclo Weight $(\mathrm{kg})$
Accossories $(\mathrm{kg})$
Vehicle Frontal Area (sq. m)
Basic Material Salvage Value $(\$ \mathrm{~kg})$
Lifte of Vehicle (yr)
Distance Traveled (km/yr)
Life Cycle Distanco Traveled (km)

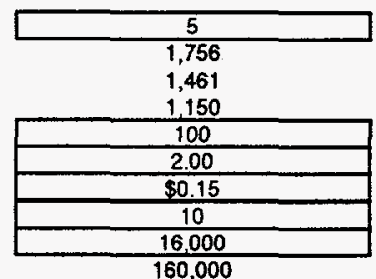

Vehicle Performance Characteristic:

Acceleration to $88 \mathrm{Km} / \mathrm{h}$ (s)

Top Speed $(\mathrm{km} / \mathrm{h})$

Gradability (\%)

Rolling Friction Coefficient ( $\mathbf{k m} / \mathbf{k m})$

Aerodynamic Drag Coefficient

Peak Power: (kW)

Driving Schodule

Battery Power-to-Energy Ratio

Range $(\mathrm{km})$

Full Cycles per year

Partial Cycles per year

\begin{tabular}{|c|}
\hline 20 \\
110 \\
7 \\
0.011 \\
0.470 \\
\hline 40.86 \\
\hline Mod. FUDS \\
NA \\
400 \\
40 \\
355
\end{tabular}

Propulsion Syatem Characteristic

POW:

Engine Power (kW)

Specific Power (kW/kg)

Specitic Cost (\$/kW)

Engine Weight $(\mathrm{kg})$

Fuel Efficiency: (kml) gasoline equiv

$$
\text { (mpg) }
$$

\begin{tabular}{c}
\hline Spark lonition \\
\hline 40.86 \\
\hline 0.45 \\
$\$ 40$ \\
91 \\
\hline 9.00 \\
\hline 21.17
\end{tabular}

\section{Enargy Sourco}

Conventional Gasoline

Fuel Cost (\$N1)

Fuel Efficiency $(\mathrm{l} / \mathrm{km})$

Electricity Cost (\$/kWhr)

Fuel Efficiency (kWhr/km)

$\$ 0.38$

Drive Train

Fuel Coll:

Power Rating (kW)

Specitic Power [Continuous] ( $k W / k g$ )

Power Density [Continuous] (kW/I)

Efficiency

Specific Cost $(\$ / \mathrm{kW})$

Woight (kg)

Fuel Efficiency: $(\mathrm{km} / \mathrm{i})$

(mpg)

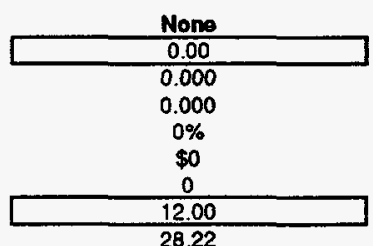

Motor

Peak Power (kW)

Specific Power (kW/kg)

Woight $(\mathrm{kg})$

Controller

Peak Power (kW)

Specific Power $(\mathrm{kW} / \mathrm{kg})$

Weight $(\mathrm{kg})$

Tranemiasion System

Peak Power (kW)

Power Rating (kW)

Energy Capacty ( $(\mathrm{WW})$

Specific Energy ( $W / \mathrm{h} / \mathrm{kg})$

Specific Power (W/kg)

Efficiency $(\%)$

Cyde Life

Specific Cost (\$/kW)

Weight (kg)

$80 \%$ Full Range Discharge $(\mathrm{km})$

Number of Replacements

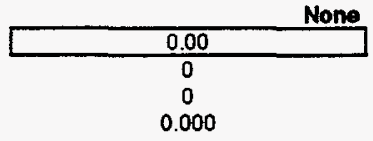

Specitic Power $(\mathrm{kW} / \mathrm{kg})$

Woight $(\mathrm{kg})$

Drive Train Efficiency (\%)

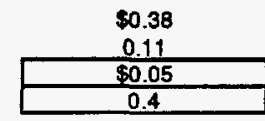

Fuel Tank

Material

Specific Weight (gm/cc)

Specific Cost $(\$ / \mathrm{kg})$

Tank Capacity: (I)

Tank Weight (w/ Fuel) (kg)

\section{Economic Analysis Factors}

Analysis base year

Present Value Discount Rate (\%100)

Cost Escalation[inflation] Rate $(\% 100)$

\begin{tabular}{|c|}
\hline 1992 \\
\hline 0.080 \\
\hline 0.045 \\
\hline
\end{tabular}

Cost of Capital $(\% / 100)$

Loan Term $(y r)$

Down payment $(\%)$

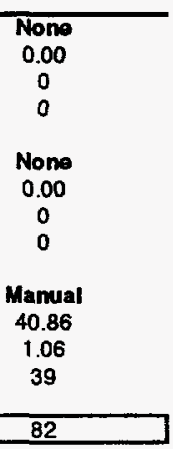

End of inout Soction 


\section{Life Cycle Cost Summary}

\section{2}

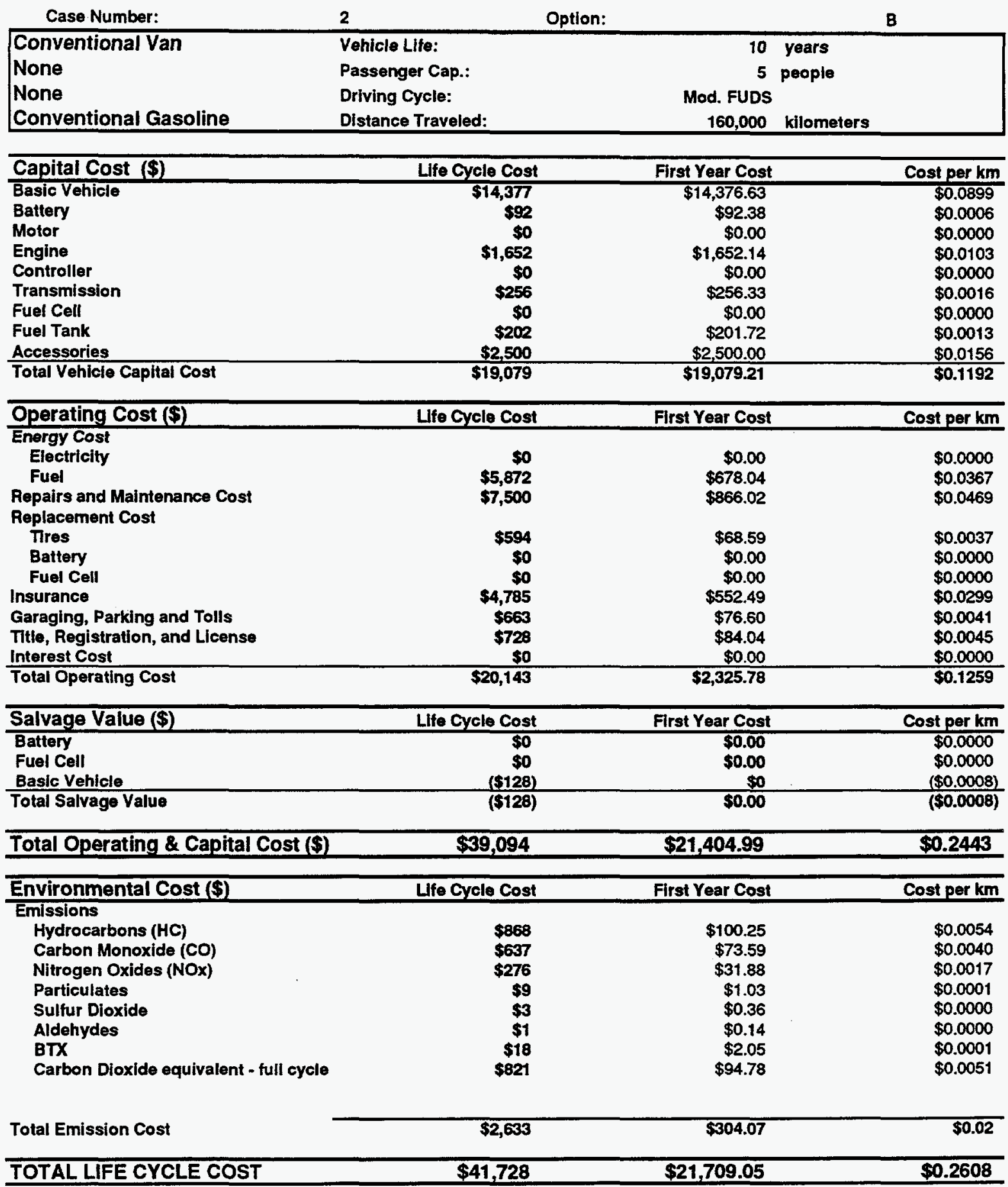


Life Cycle Cost Summary

\begin{tabular}{|c|c|c|c|c|c|c|c|c|c|c|c|c|c|}
\hline & $\begin{array}{l}\text { Conventional Van } \\
\text { Cass Number: } \\
\text { Optlon }\end{array}$ & $\begin{array}{l}2 \\
B \\
\end{array}$ & $\begin{array}{l}\text { ICEFIUN Call: } \\
\text { Bation: } \\
\text { Fud: }\end{array}$ & $\begin{array}{l}\text { Spark tgnitlon } \\
\text { None } \\
\text { Conventlonal aesolline }\end{array}$ & & & $\begin{array}{l}\text { Votwelo Lib: } \\
\text { DAtving Cycle: } \\
\text { Dlotences: }\end{array}$ & $\begin{array}{r}\text { Mod. } \\
160 \\
\end{array}$ & $\begin{array}{l}\text { yoars } \\
\text { Kilometers }\end{array}$ & $\begin{array}{l}\text { Cost } \\
\text { conte } \\
\text { Preater }\end{array}$ & 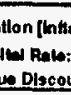 & Anto: & $\begin{array}{l}0.045 \\
0.080 \\
0.080\end{array}$ \\
\hline Cost Components & & $\begin{array}{l}\text { Prosont Vatus } \\
1002\end{array}$ & $\begin{array}{c}\text { Firu Yaur } \\
1092\end{array}$ & $\begin{array}{c}\text { Your } 2 \\
1093 \\
\end{array}$ & $\begin{array}{c}\text { rear } 3 \\
1004 \\
\end{array}$ & $\begin{array}{r}r \text { rom } 4 \\
1905 \\
\end{array}$ & $\begin{array}{r}\text { Your } 5 \\
1996 \\
\end{array}$ & $\begin{array}{c}\text { Yours } \\
1007 \\
\end{array}$ & $\begin{array}{r}\text { rour } \\
1008\end{array}$ & $\begin{array}{l}\text { Your } 8 \\
1000\end{array}$ & $\begin{array}{r}\text { Your } 0 \\
2000 \\
\end{array}$ & $\begin{array}{c}r_{\text {and }} 10 \\
2001 \\
\end{array}$ & $\begin{array}{c}\text { Cumulative } \\
\text { Oulleve }\end{array}$ \\
\hline & 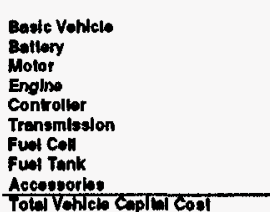 & $\begin{array}{r}\$ 14,376.63 \\
\$ 82.38 \\
\$ 0.00 \\
\$ 1,662.14 \\
\$ 0.00 \\
\$ 250.33 \\
\$ 0.00 \\
\$ 201.72 \\
\$ 2500.00 \\
\$ 10,070.21\end{array}$ & $\begin{array}{r}\$ 14,370.63 \\
\$ \$ 2.38 \\
\$ 0.00 \\
\$ 1,062.14 \\
\$ 0.00 \\
\$ 256.33 \\
\$ 50.00 \\
\$ 201.72 \\
\$ 2.500 .00 \\
\$ 10,000.21 \\
\end{array}$ & & & & & & & & . & & 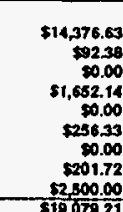 \\
\hline
\end{tabular}

Operating \& Maintenance Costs

\begin{tabular}{|c|c|c|c|c|c|c|c|c|c|c|c|c|}
\hline 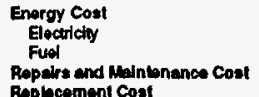 & $\begin{array}{r}\$ 5.00 \\
\$ 56.872 .40 \\
\$ 7,500 \wedge 1\end{array}$ & $\begin{array}{l}\$ 50.00 \\
\$ 677.04 \\
8686.02\end{array}$ & $\begin{array}{r}50.00 \\
75085 \\
7004.00\end{array}$ & $\begin{array}{r}50.00 \\
5740.44 \\
89045.71\end{array}$ & $\begin{array}{r}\$ 0.00 \\
\$ 773.76 \\
\$ 5088.27\end{array}$ & $\begin{array}{r}\$ 0.00 \\
\$ 808.58 \\
\$ 1,062.74\end{array}$ & $\begin{array}{r}\$ 0.00 \\
\$ 844.96 \\
\$ 1,070.21\end{array}$ & $\begin{array}{r}\$ 0.00 \\
\quad \begin{array}{r}882.99 \\
\$ 1,127.78\end{array}\end{array}$ & $\begin{array}{r}\$ 0.00 \\
\$ 922.72 \\
\$ 1,178.53\end{array}$ & $\begin{array}{r}\$ 0.00 \\
\$ 1.424 .24 \\
\$ 1.231 .56\end{array}$ & $\begin{array}{l}\$ 1.00 .000 \\
\$ 1,206.03\end{array}$ & 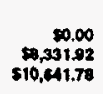 \\
\hline 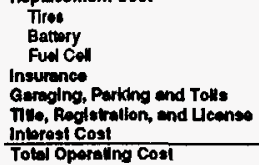 & 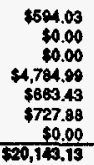 & 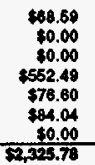 & 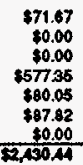 & 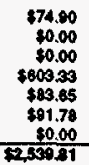 & 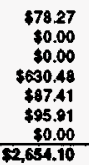 & $\begin{array}{r}\$ \$ 1.70 \\
80.00 \\
\$ 0.00 \\
\$ \$ 50.06 \\
\$ 11.35 \\
\$ 10022 \\
\$ 0.00 \\
\$ 2,73.53\end{array}$ & 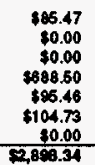 & 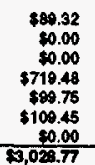 & 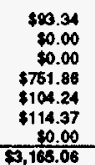 & 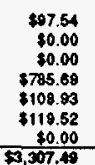 & $\begin{array}{r}\$ 101.83 \\
\$ 0.00 \\
\$ 0.00 \\
\$ 821.06 \\
\$ 113.24 \\
\$ 124.90 \\
\$ 0.00 \\
\$ .0166 .23 \\
\end{array}$ & 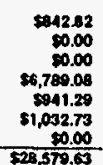 \\
\hline
\end{tabular}

Salvago Value

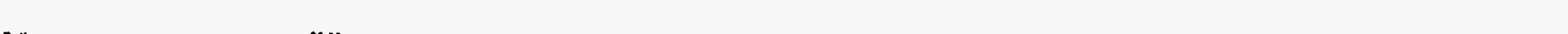

\begin{tabular}{|c|c|c|c|c|c|c|c|c|c|c|c|c|c|}
\hline Salvage Value & 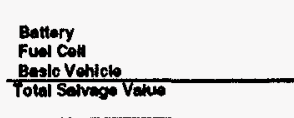 & $\begin{array}{r}50.00 \\
\$ 0.00 \\
(\{120.25 \\
(3122.23)\end{array}$ & $\$ 0.00$ & $\$ 0.00$ & $\infty 0.00$ & $\$ 0.00$ & $\$ 0.00$ & $\$ 0.00$ & $\infty .00$ & $\$ 0.00$ & $\$ 0.00$ & $\begin{array}{r}80.00 \\
80.00 \\
-(2556.38) \\
(5258.38)\end{array}$ & 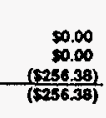 \\
\hline Total Operating \& Capltal Cost & & $\$ 200200$ & \$1,0402 & $92,30.44$ & 253981 & 2.034 .10 & $2 ., 72.53$ & 28.890 .34 & $\$ 3,028 . \pi$ & $\$ 0.165 .06$ & $00,307.49$ & $0,199.98$ & $\$ 47,402.4$ \\
\hline Environmental Costs & 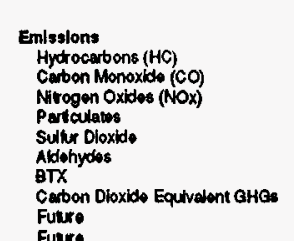 & 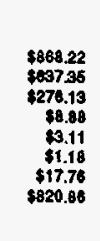 & 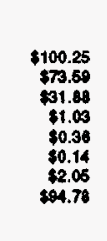 & 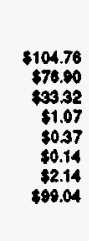 & 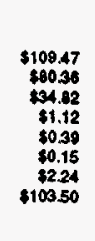 & 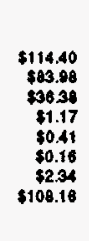 & 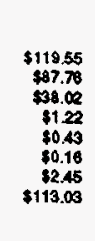 & 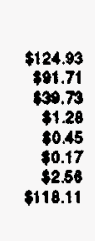 & 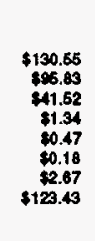 & 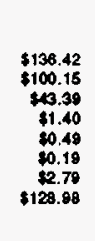 & 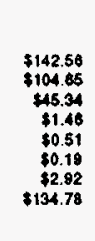 & 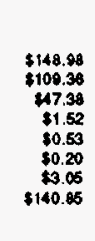 & 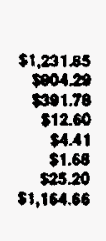 \\
\hline & Tothertaston cost & $\$ 2,039,49$ & Wकम.ण & \$17.73 & \$332.05 & $\$ 26,00$ & $\$ 362.61$ & $\$ 778.93$ & $\$ 30.98$ & म्र13.20 & $\mathscr{4 0 2 . 4 2}$ & 961,18 & $50,738,46$ \\
\hline TOTAL LIFE CYCLE COST & & B1,727.57 & $\mathbf{8 1 , 7 0 8 , 0 3}$ & $22,748.19$ & $\$ 2,871.86$ & $\$ 0,001.00$ & $\$ 0, \mathbf{1 3 6 , 1 4}$ & $\$ 0,277.27$ & $8,424.74$ & $\$ 3,578.86$ & $\$ 3,730.91$ & $\$ 0,651,62$ & $\$ 01,138.93$ \\
\hline
\end{tabular}




\section{LIFE CYCLE COST MODEL INPUT MODULE}

Case Number: Basic Vehicle Configuration

Technology Options
Type of Vehicle
Power System
Type of ICE
Type of Fuel Cell
Type of Fuel
Type of Battery Propulsion
Type of Motor/Controller
Type of Transmission
Status of Technology

Option:

Conventional Auto
ICE
Compression Ignition
None
Conventional Diesel
None
None
Automatic
Low

A

Options
$1-8$
$1-3$
$0-2$
$0-2$
$0-8$
$0, A-C: 1-10$
$0-3$
$1-2$
Low/High

Vehicle Performance Characteristics

Acceleration to $B 8 K \mathrm{Km} / \mathrm{h}$ (s)

Top Speed ( $\mathrm{km} / \mathrm{h})$

Gradability (\%)

Rolling Friction Coefficient (km/km)

Aerodynamic Drag Coefficient

Peak Power: (kW)

Driving Schedule

Battery Power-to-Energy Ratio

Range (km)

Full Cyctes per year

Partial Cycles per year

\begin{tabular}{|c|}
\hline 20 \\
110 \\
7 \\
0.010 \\
0.320 \\
\hline 30.00 \\
\hline Mod. FUDS \\
NA \\
400 \\
40 \\
355
\end{tabular}

Distance Traveled (km/yr)

Life Cycle Distance Traveled (km)

160,000

\section{Energy Source}

Conventional Diesel

Specitic Cost (\$kW)

Engine Weight $(\mathrm{kg})$

Fuel Etticiency: (km/) gasoline equiv (mpg)

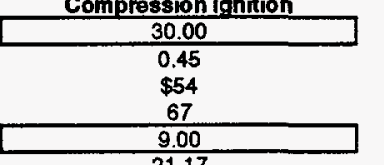

Fuel Cell:

Power Rating (kW)

Power Density [Continuous] (kW/1)

Efficiency

Specitic Cost (\$/kW)

Weight (kg)

Fuel Efficiency: (km/)

(mpg)

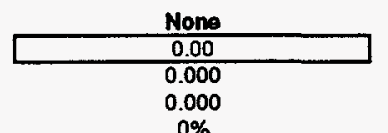

0.000

$0 \%$

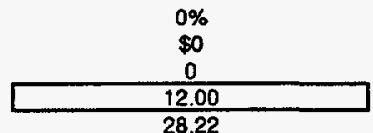

Battery:

Power Rating (kW)

Energy Capacity (kWh)

Specific Energy (Wh/kg)

Specitic Power (W/kg)

Efficiency (\%)

Cycle Lifo

Specitic Cost $(\$ / \mathrm{kW})$

Weight (kg)

$80 \%$ Full Range Discharge $(\mathrm{km})$

Number of Replacements

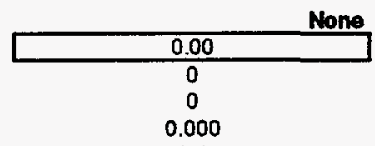

Fuel Cost (\$/l)

Fuel Efficiency ( $/ \mathrm{km})$

Electricity Cost (\$/kWhr)

Fuel Efficiency (kWhr/km)

Drive Train

Motor

Peak Power (kW)

Specific Power (kW/kg)

Weight (kg)

Controller

Peak Power (kW)

Specitic Power (kW/kg)

Woight (kg)

Tranemission System

Peak Power (kW)

Specific Power ( $\mathrm{kW} / \mathrm{kg}$ )

Weight (kg)

Drive Train Efficiency (\%)

$\$ 0.39$

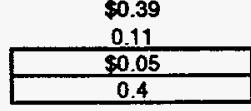

Fuel Tank

Material

Specific Weight (gm/cc)

Specific Cost ( $\$ / \mathrm{kg})$

Tank Capacity: (I)

Tank Weight (w/ Fuel) (kg)

Cost of Capital $(\% / 100)$

Loan Term (yr)

Down payment (\%)
Theng

0.00

0

None

0.00

0

Automatic

30.00

0.86

35

82

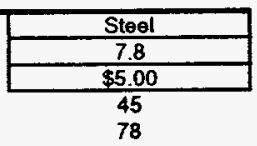

\begin{tabular}{|c|}
\hline 0.08 \\
\hline 0 \\
\hline $100 \%$ \\
\hline
\end{tabular}

Economic Analysis Factors

Analysis base year

Present Value Discount Rate $(\% 100)$

Cost Escatation[Inflation] Rate (\%100)

\begin{tabular}{|c|}
\hline 1992 \\
\hline 0.080 \\
\hline 0.045 \\
\hline
\end{tabular}

End of Input Section 


\section{Life Cycle Cost Summary}

1992

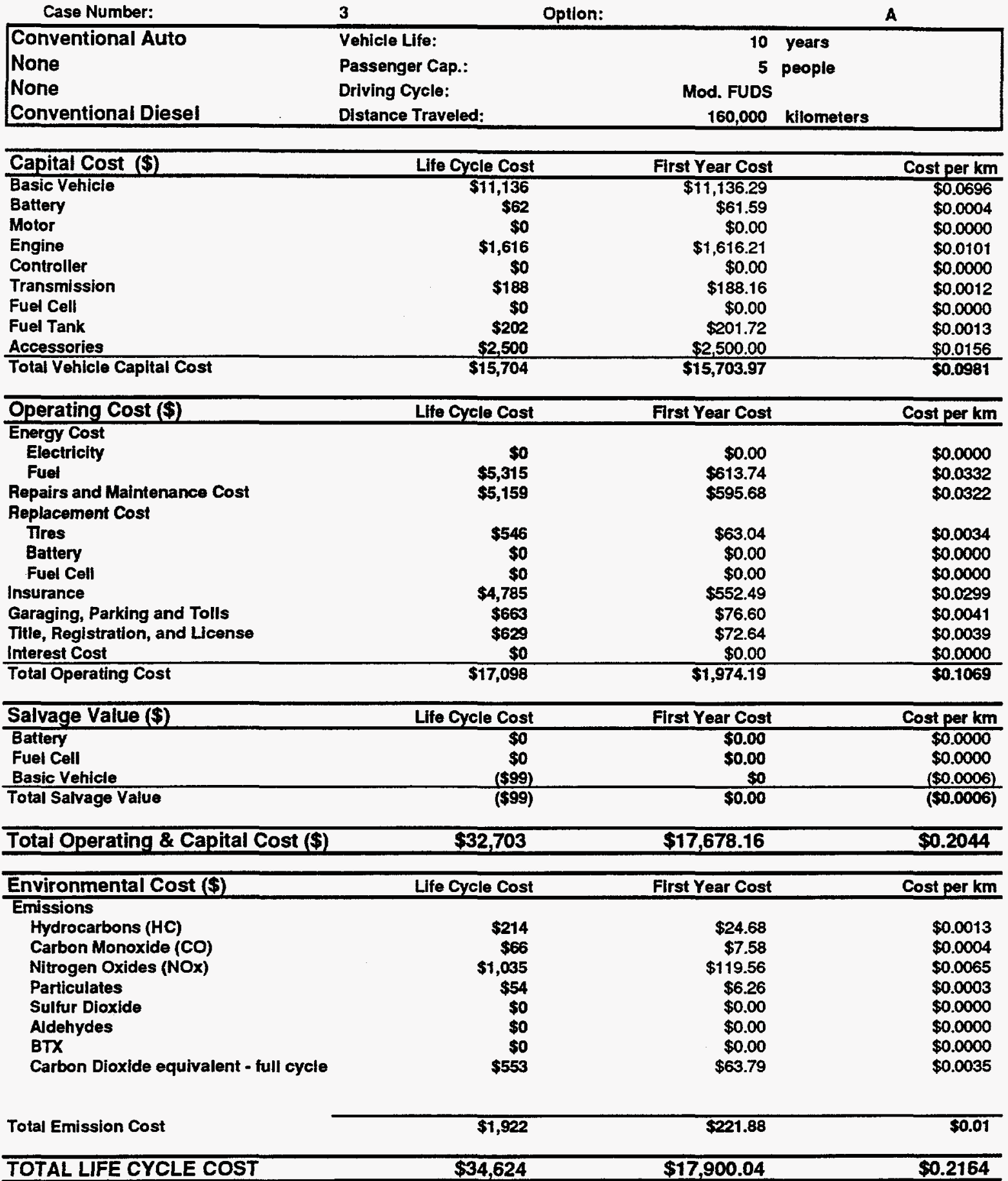




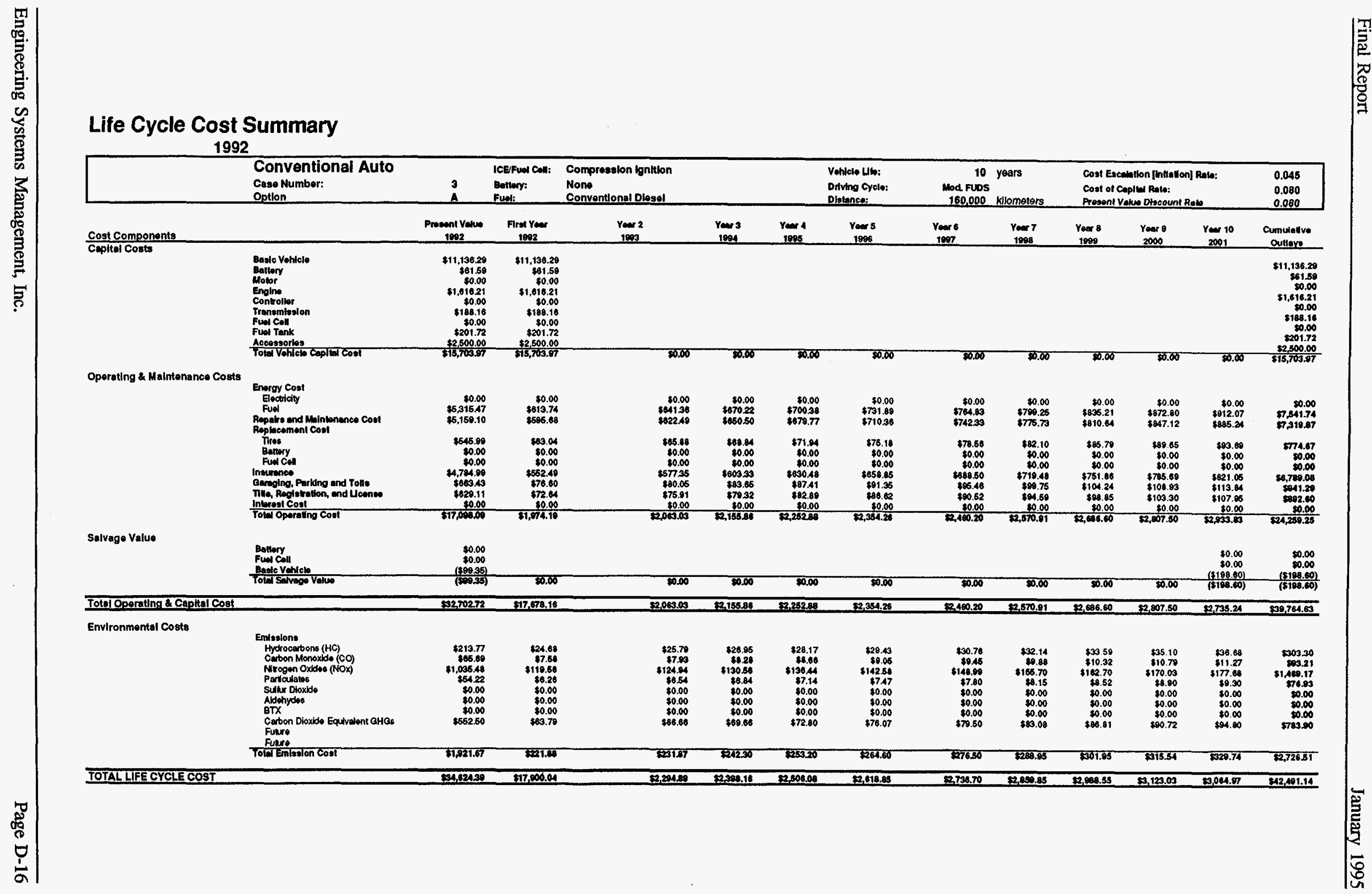




\section{LIFE CYCLE COST MODEL INPUT MODULE}

Gase Number:

Basic Vehicle Configuration

Technology Options

Type of Vehicle

Power System

Type of ICE

Type of Fuel Cell

Type of Fuel

Type of Battery Propulsion

Type of Motor/Controller

Type of Transmission

Status of Technology

\begin{tabular}{|c|}
\hline Input \\
\hline 1 \\
\hline 1 \\
\hline 1 \\
\hline 0 \\
\hline 3 \\
\hline 0 \\
\hline 0 \\
\hline 1 \\
\hline Low \\
\hline
\end{tabular}

Option:

Conventional Auto

ICE

Spark Ignition

None

Methanol (M100)

None

None

Automatic

Low

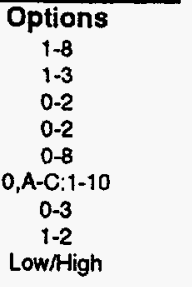

Vehicle Performance Characteristics

Accoleration to B8Km/h (s)

Top Speed $(\mathrm{km} / \mathrm{h})$

Gradability (\%)

Aolling Friction Coefficient ( $\mathrm{km} / \mathrm{km}$ )

Aerodynamic Drag Coefficient

Peak Power: (kW)

Driving Schedule

Battery Power-to-Energy Ratio

Pange (km)

Full Cycles per year

Partial Cycles per year

110

Base Vehicle Weight $(\mathrm{kg})$

Accessories $(\mathrm{kg})$

Basic Material Salvage Value $(\$ / k g)$

Life of Vehicle (yr)

Distance Traveled (km/yr)

Life Cycle Distanco Traveled $(\mathbf{k m})$

16,000

160,000

Propulsion System Characteristics Power Sysiem

TCE:

Engine Power (kW)

Specific Power (kW/kg)

Specitic Cost (\$/kW)

Engine Weight (kg)

Fuel Efficiency: (km/) gasoline equiv (mpg)

\begin{tabular}{|c|}
\hline Spark Ignition \\
\hline 30.00 \\
\hline 0.45 \\
$\$ 50$ \\
67 \\
\hline 9.00 \\
\hline 21.17
\end{tabular}

\section{Enargy Source}

Wothanol (M100)

Fuel Cost (\$/)

Fuel Efticiency ( $/ \mathrm{km})$

Electricity Cost (\$/kWhr)

Fuel Efficiency (kWhr/lom)

20
110

110

0.010

0.010
0.320

30.00

Mod, FUDS

NA
400

40

355

Drive Train

Notor

Peak Power (kW)

Specific Power (kW/kg)

Weight (kg)

Specific Power [Continuous] (kW/kg)

Power Density [Continuous] (kW/I)

Efficiency

Specific Cost $(\$ / k W)$

Woight (kg)

Fuel Efficiency: (km/)

(mpg)

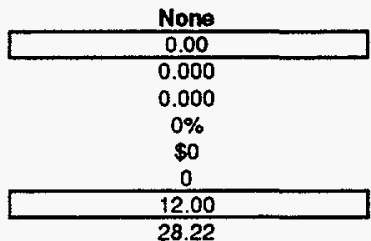

Controller

Peak Power (kW)

Specific Power ( $\mathrm{kW} / \mathrm{kg}$ )

Weight (kg)

Transmission System

Peak Power (kW)

Specitic Power ( $\mathrm{kW} / \mathrm{kg}$ )

Weight (kg)

Power Rating (kW)

Energy Capacity (kWh)

Specific Energy (Wh/kg)

Spactic Power ( $W / \mathrm{kg})$

Efficiency $(\%)$

Cycle Life

Specific Cast (\$/kW)

Woight (kg)

$80 \%$ Full Range Discharge (km)

Number of Replacements

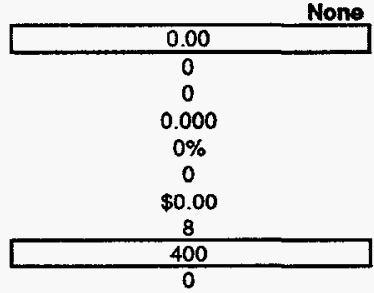

Drive Train Etficiency (\%)

Fuel Tank

Material

Specitic Weight ( $\mathrm{gm} / \mathrm{cc})$

Specific Cost (\$/kg)

Tank Capacity: (I)

Tank Weight (w/ Fuel) (kg)

\begin{tabular}{|c|}
$\$ 0.25$ \\
0.11 \\
\hline$\$ 0.05$ \\
\hline 0.4 \\
\hline
\end{tabular}

Economic Analysis Factors

Analysis base year

Present Value Discount Rate (\%100)

Cost Escalation[Inflation] Rate $(\% 100)$

\begin{tabular}{|c|}
\hline 1992 \\
\hline 0.080 \\
\hline 0.045 \\
\hline
\end{tabular}

Cost of Capital $(\% / 100)$

Loan Term (yr)

Down payment $(\%)$
None

0.00

None

0.00

Automatic

30.00

0.86

35

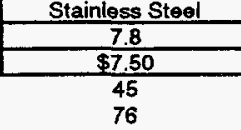

End of Input Soction 


\section{Life Cycle Cost Summary}

\section{2}

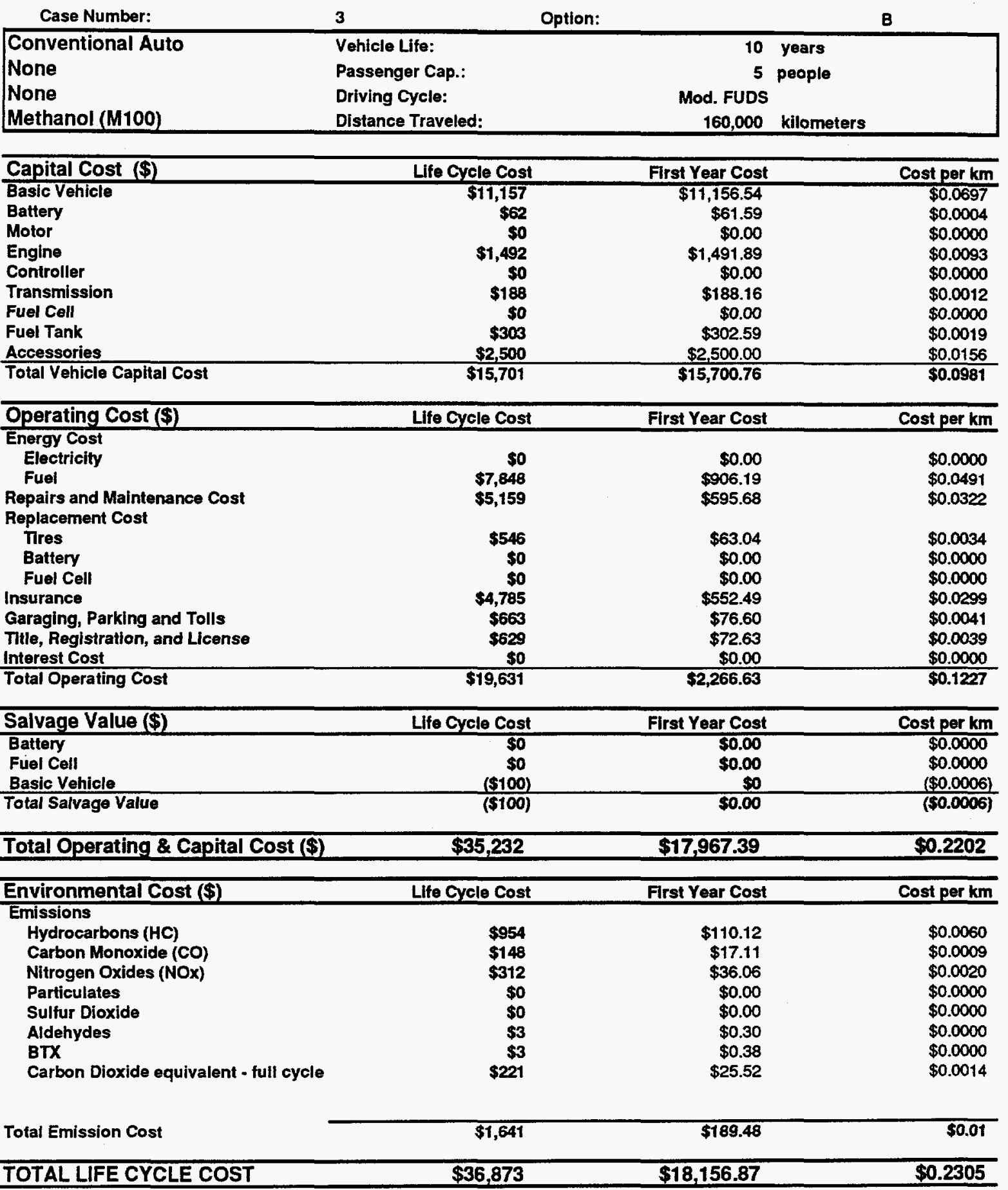




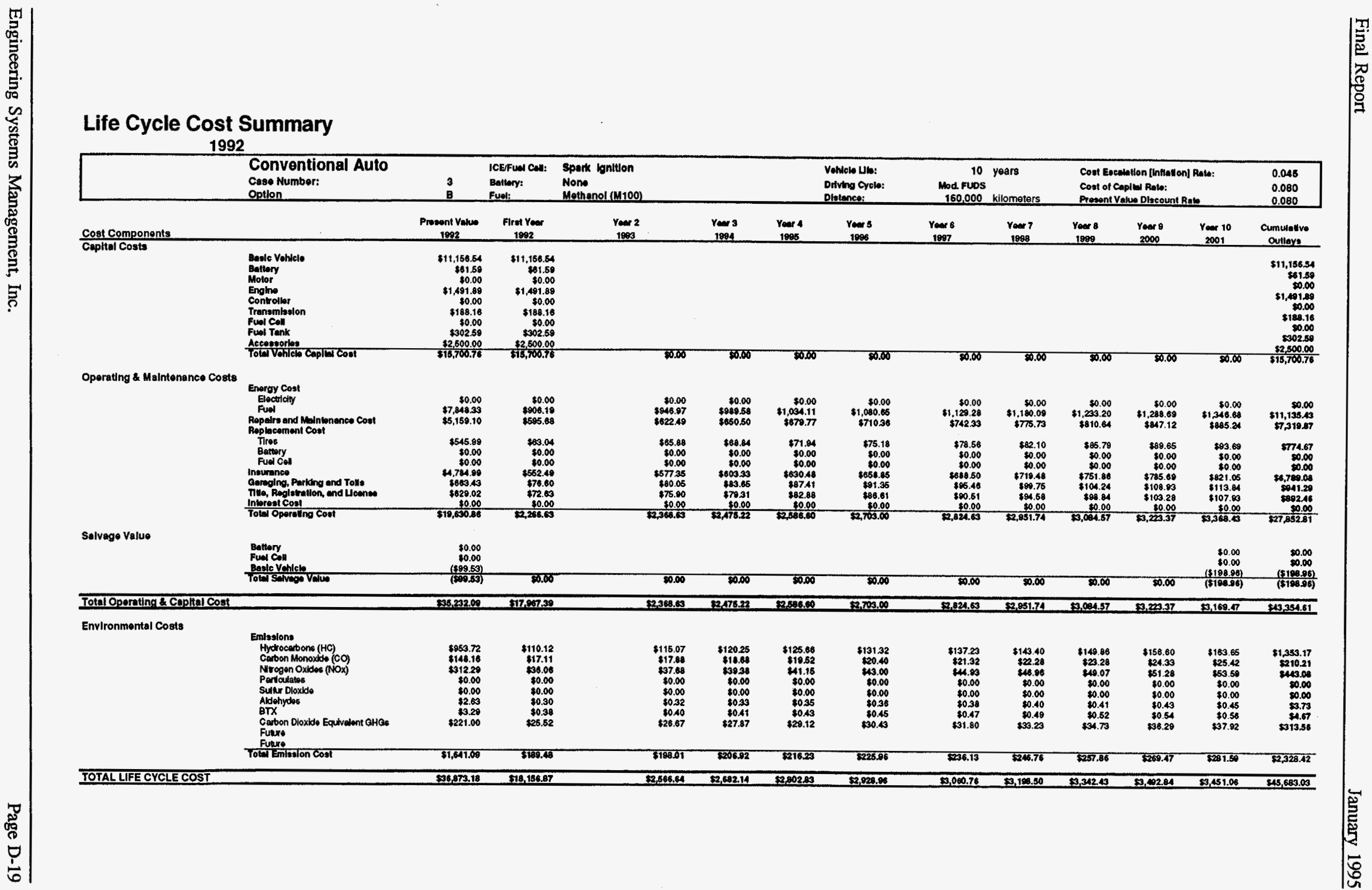




\section{LIFE CYCLE COST MODEL INPUT MODULE}

Caso Number:

Basic Vehicle Contiguration

Technology Options

Type of Vehicle

Power System

Type of ICE

Type of Fuel Cell

Type of Fuel

Type of Battery Propulsion

Type of Motor/Controller

Type of Transmission

Status of Technology
Option:

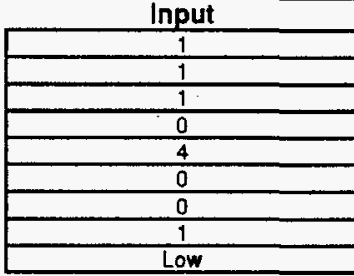

Conventional Auto

ICE

Spark Ignition

None

Ethanol (E100)

None

None

Automatic

Low
Options

1-8

$1-3$

$0-2$

$0-8$

$0, A-C: 1-10$

$0-3$

Low/High

Vehicle Physical Characteristics

Conventional Aưto

Passenger Capacity $(2,4,5,6+, 10+)$

Test Weight (kg)

Curb Weight (kg)

Base Vehicle Weight (kg)

Accessories (kg)

Vehicle Frontal Area (sq. m)

Basic Material Salvage Value $(\$ / \mathrm{kg})$

Life of Vehicle (yr)

Distance Traveled (km/yr)

Life Cycle Distance Traveled $(\mathrm{km})$

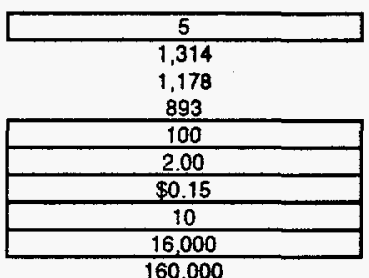

160,000

Vehicle Performance Characteristics

Accoleration to $88 \mathrm{Km} / \mathrm{h}$ (s)

Top Speed $(\mathrm{km} / \mathrm{h})$

Gradability (\%)

Rolling Friction Coefficient $(\mathrm{km} / \mathrm{km})$

Aerodynamic Drag Coefficient

Peak Power: (kW)

Driving Schedule

Battery Power-to-Energy Ratio

Pange (km)

Full Cycles per year

Partial Cycles per year

20

20

0.320

30.00

Mod. FUDS

NA

400

40

355

Propulsion Syatem Characteriatics Power System

TCE:

Engine Power ( $k W$ )

Specific Power (kW/kg)

Specific Cost (\$/kW)

Engine Weight $(\mathrm{kg})$

Fuel Efficiency: $(\mathrm{km} /)$ gasoline equiv (mpg)

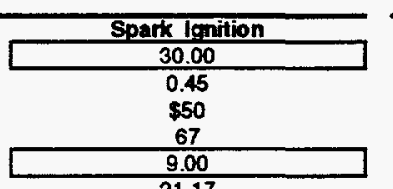

\section{Enerer Source}

Ethanol (E100)

Fuel Cost (\$/1)

Fuel Efficiency ( $(\mathbf{k m})$

Electricity Cost (\$/kWhr)

Fusl Efficiency (kWhr/km)

$\$ 0.42$

Drive Train

Peak Power (kW)

Fuel Cell:

Power Rating (kW)

Specific Power [Continuous] (kW/kg)

Power Density [Continuous] (kW/I)

Efficiency

Specific Cost (\$kW)

Weight (kg)

Fuel Efficiency: (km/l)

(mpg)

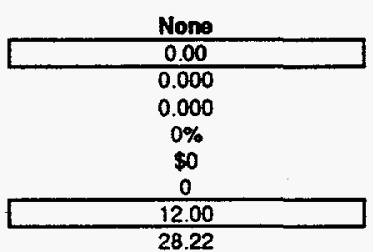

Specific Power (kW/kg)

Woight (kg)

Controller

Peak Power (kW)

Specific Power $(\mathrm{kW} / \mathrm{kg})$

Woight (kg)

0.11

$\$ 0.05$

Battery:

Power Rating (kW)

Energy Capacity (kWh)

Specific Energy (Wh/kg)

Specitic Power (W/kg)

Efficiency $(\%)$

Cycle Lifo

Specific Cost (\$/kW)

Weight (kg)

$80 \%$ Full Range Discharge (km)

Number of Replacements

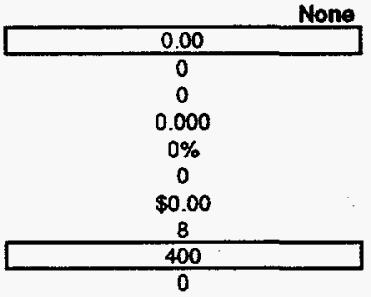

Transmission System

Peak Power (kW)

Specific Power ( $\mathrm{kW} / \mathrm{kg}$ )

Woight $(\mathrm{kg})$

Drive Train Efficiency (\%)

None

0.00

0

Fuel Tank

Material

Specific Weight (gm/cc)

Specific Cost (\$/kg)

Tank Capacity: (i)

Tank Weight (w/ Fuel) (kg)

None

0.00

Economic Analysis Factors

Analysis base year

Present Value Discount Rate (\%/100)

Cost Escalation[Inflation] Rate $(\% / 100)$

\begin{tabular}{|c|}
\hline 1992 \\
\hline 0.080 \\
\hline 0.045 \\
\hline
\end{tabular}

Cost of Capital (\%/100)

Loan Term (yr)

Down payment $(\%)$

End of Inpur Soction 


\section{Life Cycle Cost Summary}

\section{2}

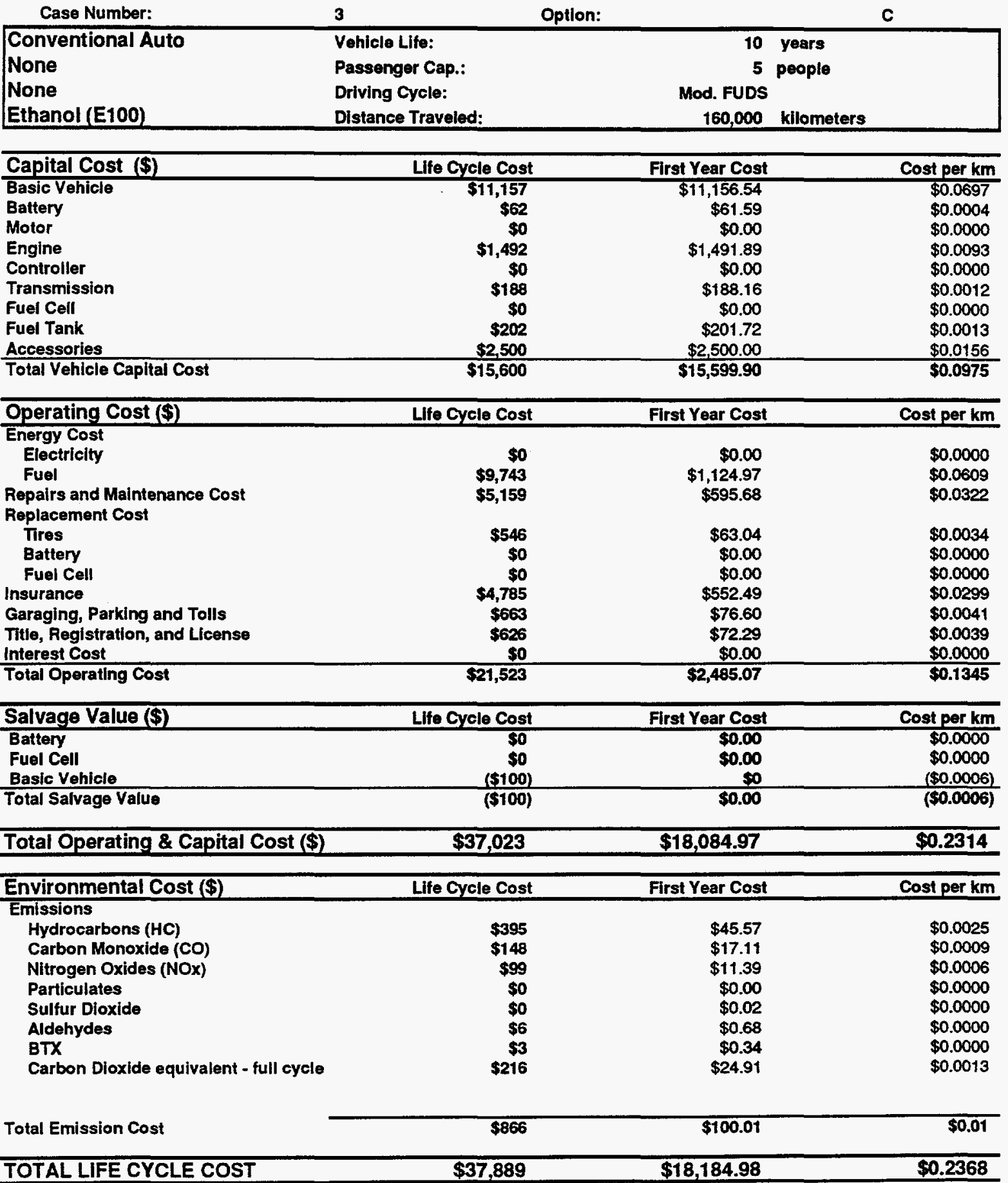




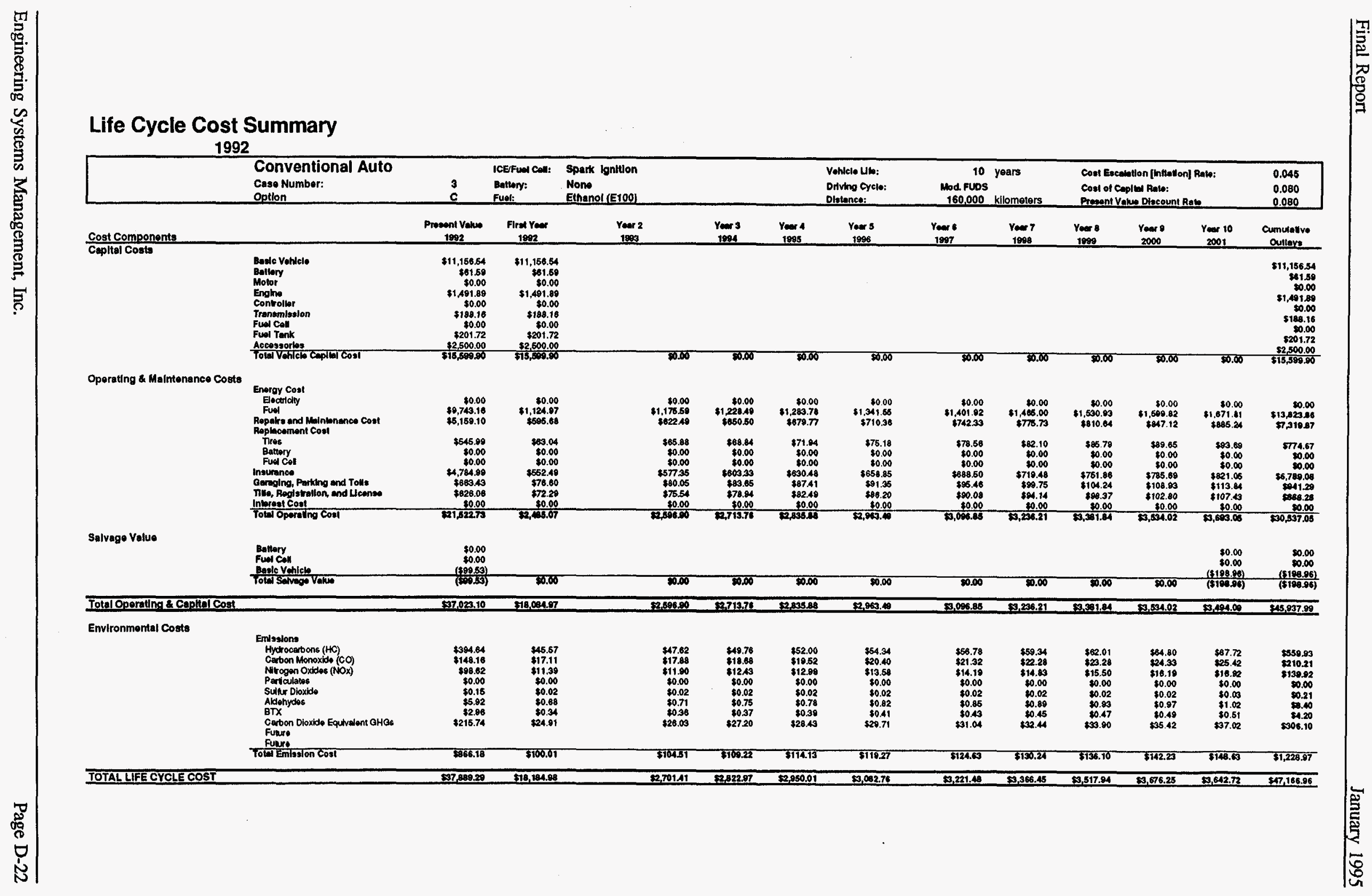




\section{LIFE CYCLE COST MODEL INPUT MODULE}

Case Number:

Option:

D

Basic Vehicle Configuration

Technology Options

Type of Vehicle

Power System

Type of ICE

Type of Fuel Cell

Type of Fuel

Type of Battery Propulsion

Type of Motor/Controller

Type of Transmission

Stafus of Technology

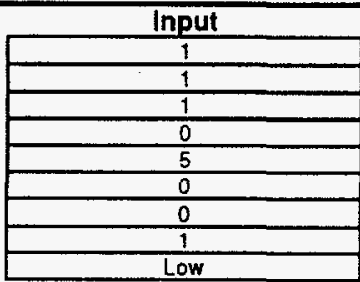

Conventional Auto

ICE

Spark lgnition

None

Methane (CNG)

None

None

Automatic

Low

Options
$1-8$
$1-3$
$0-2$
$0-2$
$0-8$
$0, A-C: 1-10$
$0-3$
$1-2$
Low/High

\section{Vehicle Physical Characteristics}

Conventional Auto

Passenger Capacity $(2,4,5,6+, 10+)$

Test Weight (kg)

Curb Weight $(\mathrm{kg})$

Base Vehicle Weight $(\mathrm{kg})$

Accessories (kg)

Vehicle Frontal Area (sq. m)

Basic Material Salvage Value $(\$ / \mathrm{kg})$

Lite of Vehicle (yr)

Distance Traveled (km/yr)

Life Cycle Distance Traveled $(\mathbf{k m})$

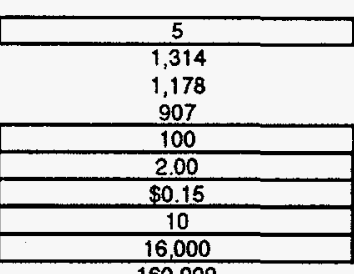

160,000

Vehicle Performance Characteristics

Acceleration to $88 \mathrm{Km} / \mathrm{h}$ (s)

Top Speed $(\mathrm{km} / \mathrm{h})$

Gradability (\%)

Rolling Friction Coefficient ( $\mathrm{km} / \mathrm{km}$ )

Aerodynamic Drag Coefficient

Peak Power: (kW)

Driving Schedule

Battery Power-to-Energy Ratio

Range (km)

Full Cycles per year

Partial Cycies per year

Low/High

Propulsion System Characteristics Power System

TCE:

Engine Power (kW)

Specitic Power (kW/kg)

Specific Cost $(\$ / k W)$

Engine Weight $(\mathrm{kg})$

Fuel Efficiency: (km/l) gasoline equiv

(mpg)

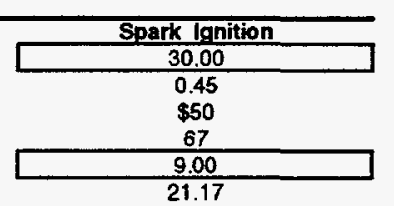

Energy Source

Mothane (CNG)

lethane (CNC)

Fuel Cost $(\$ / 1)$

Fuel Efficiency (V/km)

Electricity Cost (\$/kWhr)

Fuel Efficiency (kWhr/km)

Drive Train

Thotor

Peak Power (kW)

Specific Power (kW/kg)

Woight (kg)

Power Pating (kW)

Specitic Power [Continuous] (kW/kg)

Power Density [Continuous] (kW/)

Efficiency

Specific Cost (\$/kW)

Weight (kg)

Fuel Efficiency: $(\mathrm{km} /)$

(mpg)

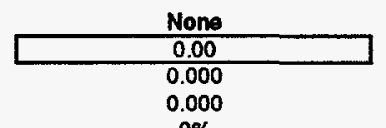

Controller

Peak Power (kW)

Specific Power (kW/kg)

Weight $(\mathrm{kg})$

Transmission System

Peak Power (kW)

Specific Power $(\mathrm{kW} / \mathrm{kg})$

Woight (kg)

Power Rating (kW)

Energy Capacity (kWh)

Specific Energy (Wh/kg)

Specific Power (W/kg)

Efficiency $(\%)$

Cycle Life

Specific Cost (\$/kW)

Weight (kg)

$80 \%$ Full Range Discharge $(\mathrm{km})$

Number of Replacements

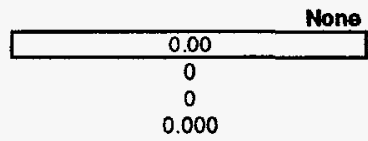

Drive Train Efficiency $(\%)$

\begin{tabular}{|c|}
\hline 20 \\
110 \\
7 \\
0.010 \\
0.320 \\
\hline 30.00 \\
\hline Mod. FU \\
NA \\
400 \\
40 \\
355
\end{tabular}

Fued Tank

\section{Materia}

Specific Weight (gm/cc)

Specific Cost (\$/kg)

Tank Capacity: (I)

Tank Woight (w/ Fuel) (kg)

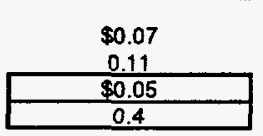

Economic Analysis Factors

Analysis base year

Present Value Discount Rate (\%100)

Cost Escalation[inflation] Rate $(\% 1100)$

\begin{tabular}{|c|}
\hline 1992 \\
\hline 0.080 \\
\hline 0.045 \\
\hline
\end{tabular}

Cost of Capital (\%/100)

Loan Term (yr)

Down payment (\%)

D

None

0.00

0

Automatic

30.00

0.86

10

10

00

A

40

5

End of Input Soction

Engineering Systems Management, Inc.

Page D-23 


\section{Life Cycle Cost Summary}

\section{2}

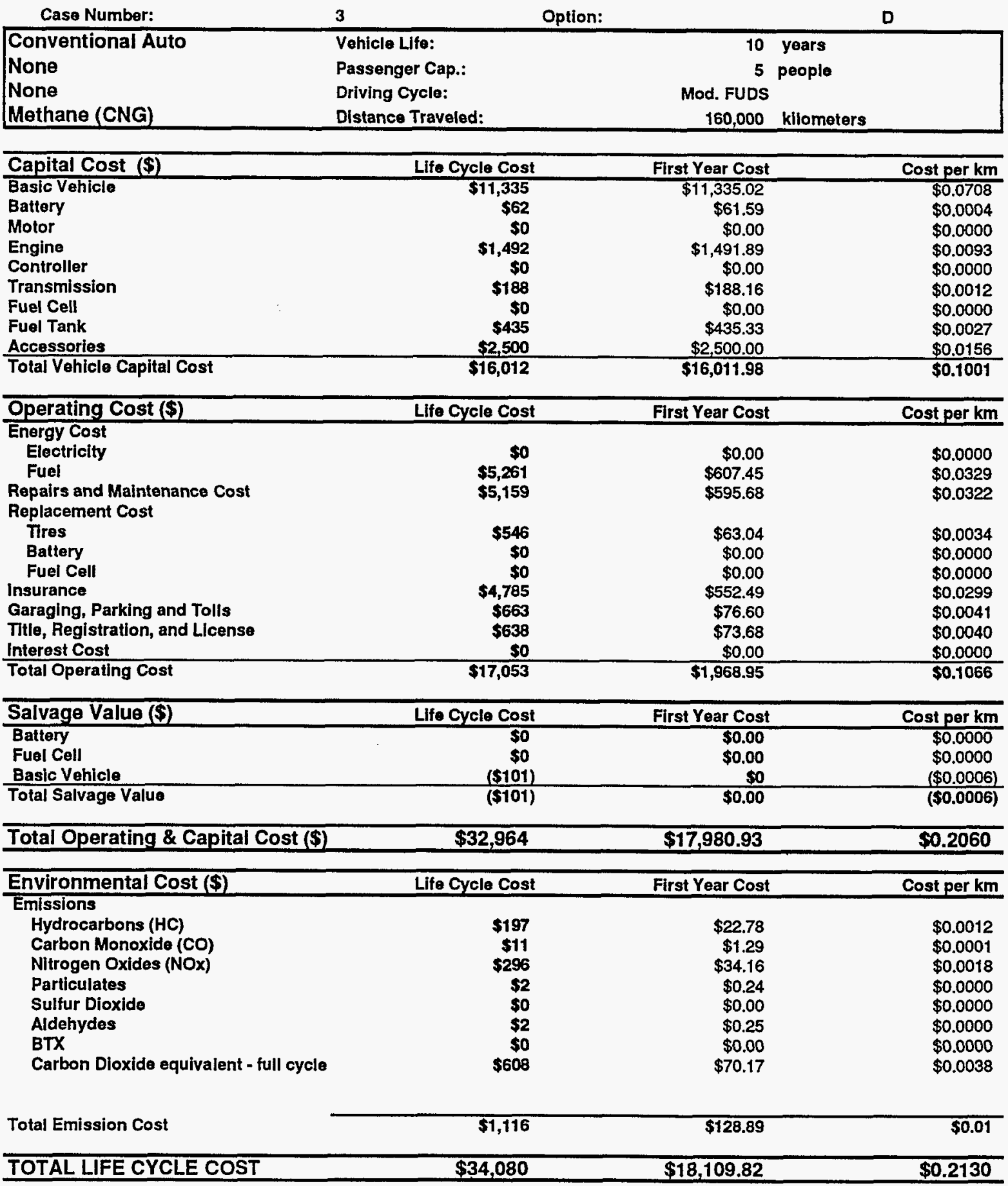




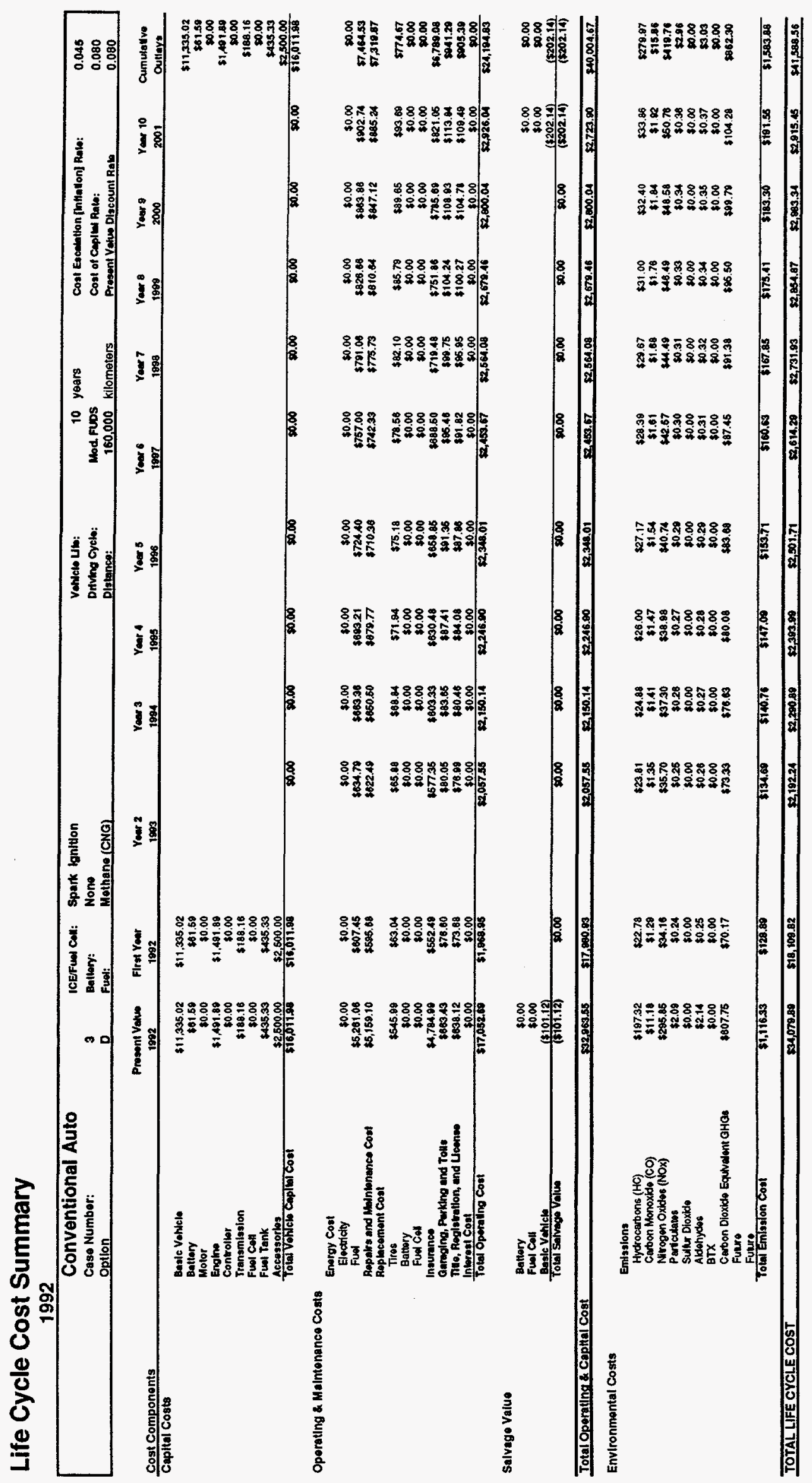




\section{LIFE CYCLE COST MODEL INPUT MODULE}

Case Number:

Basic Vehicle Configuration Technology Options

Type of Vehicle

Power System

Type of ICE

Typo of Fuel Cell

Type of Fuel

Type of Battery Propulsion

Type of Motor/Controller

Typo of Transmission

Status of Technology

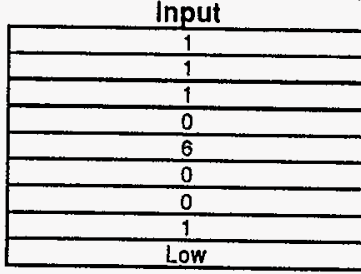

Option:

Conventional Auto

ICE

Spark Ignition

None

None

None

Automatic

Low
Reformulated Gasoline

E

Options
$1-8$
$1-3$
$0-2$
$0-2$
$0-8$
$0, A-C: 1-10$
$0-3$
$1-2$
Low/High

Vehicle Performance Characteristic:

Accoleration to $88 \mathrm{Km} / \mathrm{h}(\mathrm{s})$

Top Speed $(\mathrm{km} / \mathrm{h})$

Gradability (\%)

Rolling Friction Coofficient (km/km)

Aerodynamic Drag Coefficient

Peak Power: (kW)

Driving Schedule

Battery Power-to-Energy Ratio

Range (km)

Full Cycles per year

Partial Cycles per year

20

20

110
7

$\begin{array}{r}7 \\ 0.010 \\ 0.320 \\ \hline 30.00 \\ \hline\end{array}$

30.00

Mod. FUDS

NA

400

40

355
Life of Vehicle (yr)

Distance Traveled (km/yr)

Lifo Cycle Distance Traveled $(\mathbf{k m})$

10

60,000

Propulsion System Characteristics

Power System

TCE:

Engine Power (kW)

Specific Power $(\mathrm{kW} / \mathrm{kg})$

Specific Cost (\$/kW)

Engine Weight $(\mathrm{kg})$

Fuel Etficiency: $(\mathrm{km} / \mathrm{l})$ gasoline equiv (mpg)

Fuel Cell:

Power Rating (kW)

Specific Power [Continuous] (kW/kg)

Power Density [Continuous] (kW/I)

Efficiency

Specific Cost (\$/kW)

Woight (kg)

Fuel Efficiency: $(\mathrm{km} /)$

(mpg)

Battory:

Power Rating (kW)

Energy Capacity (kWh)

Specific Energy $(W \mathrm{~h} / \mathrm{kg})$

Specific Power ( $W / \mathrm{kg})$

Efficiency $(\%)$

Cyclo Life

Specific Cost (\$/kW)

Woight (kg)

80\% Full Range Discharge (km)

Number of Replacements

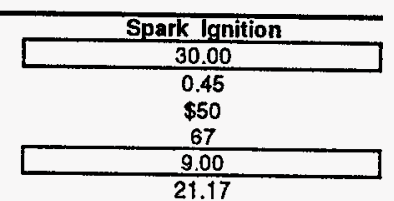

\section{Enorgy Soura}

Foformulated Gasoline

Fuel Cost (\$/I)

Fuel Efficiency $(V \mathrm{~km})$

Electricity Cost (\$/kWhr)

Fuel Efficiency (kWhr/km)

Drive Train

Thotor

Peak Power (kW)

Specitic Power (kW/kg)

Woight $(\mathrm{kg})$

Controller

Peak Power (kW)

Specific Power (kW/kg)

Woight $(\mathrm{kg})$

Transmission System

Peak Power (kW)

Specific Power $(\mathbf{k W} / \mathrm{kg})$

Woight (kg)

Drive Train Efficiency (\%)

$\$ 0.42$

0.11

$\$ 0.05$

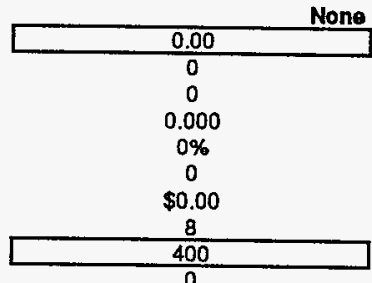

Fuel Tank

Material

Specific Weight (gm/cc)

Specific Cost (\$/ke)

Tank Capacity: (D)

None

0.00
0

0

utomatic

30.00

0.86

35

conomic Analysis Factors

Analysis base year

Present Value Discount Rate $(\% / 100)$

Cost Escalationilnflation] Rato $(\$ / 100)$

Tank Weight (w/ Fuel) (kg)

82

Cost of Capital (\%/100)

Loan Term (yr)

Down paymert $(\%)$

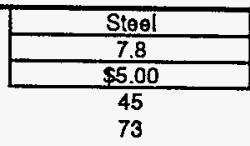

\begin{tabular}{|c|}
\hline 0.08 \\
\hline 0 \\
\hline $100 \%$ \\
\hline
\end{tabular}

End of Input Soction 


\section{Life Cycle Cost Summary}

1992

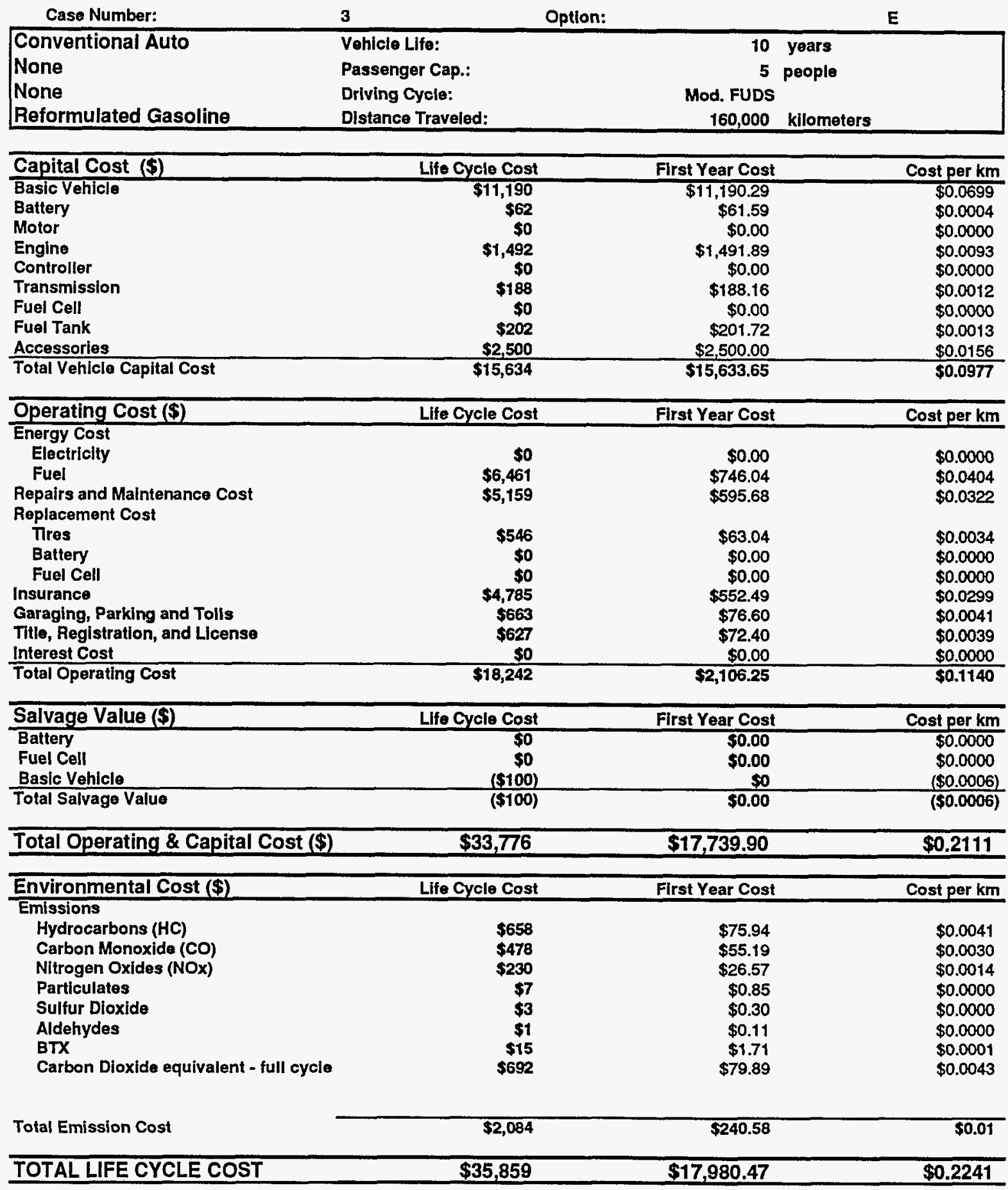


Life Cycle Cost Summary

\begin{tabular}{|c|c|c|c|c|c|c|c|c|c|c|c|c|c|}
\hline \multirow{2}{*}{$\begin{array}{l}\text { Cost Components } \\
\text { Ceppltal Costs }\end{array}$} & \multirow[t]{2}{*}{$\begin{array}{l}\text { Conventional Auto } \\
\text { Caso Number: } \\
\text { Option }\end{array}$} & \multirow{2}{*}{$\begin{array}{c}3 \\
\\
\begin{array}{c}\text { Prosont Vume } \\
1002\end{array} \\
\end{array}$} & \multirow{2}{*}{ 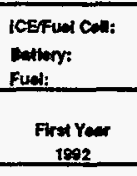 } & \multirow{2}{*}{ 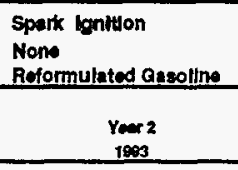 } & \multirow[b]{2}{*}{$\begin{array}{l}Y_{000} 3 \\
1004\end{array}$} & \multirow[b]{2}{*}{$\begin{array}{c}\text { Your } 4 \\
\text { 19005 }\end{array}$} & \multirow{2}{*}{ 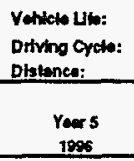 } & \multicolumn{2}{|c|}{$\begin{array}{c}10 \text { years } \\
\text { Mod, FuOS } \\
160,000 \text { kilometers } \\
\end{array}$} & \multicolumn{3}{|c|}{ 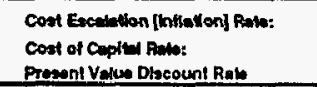 } & \multirow{2}{*}{ 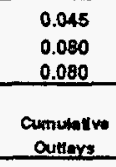 } \\
\hline & & & & & & & & $\begin{array}{l}\text { Yane } 6 \\
1987\end{array}$ & $\begin{array}{c}\text { Your } 7 \\
\text { doge }\end{array}$ & $\begin{array}{c}\text { Your I } \\
1999\end{array}$ & $\begin{array}{r}\text { Yours } \\
2000 \\
\end{array}$ & $\begin{array}{c}\begin{array}{c}\text { Yor } 10 \\
2001\end{array} \\
\end{array}$ & \\
\hline Cespltal Costs & 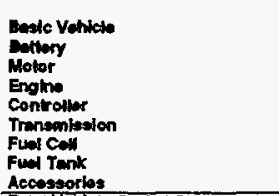 & 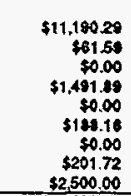 & $\begin{array}{r}\$ 11,190.29 \\
\$ 81.50 \\
\$ 0.00 \\
\$ 1,401.20 \\
\$ 0.00 \\
\$ 132.16 \\
\$ 0.00 \\
\$ \$ 2,72 \\
\$ 2,500.00 \\
\end{array}$ & & & & & & & & & & 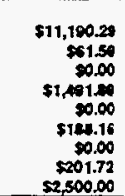 \\
\hline & 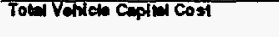 & $515,063.15$ & $515,038,85$ & $\$ 0.0$ & कod & 90 & 50.00 & & $\$ 200$ & $\$ 0.1$ & 50 & \$0. & $\$ 515,033.65$ \\
\hline
\end{tabular}

Operating \& Malntenance costs

\begin{tabular}{|c|c|c|c|c|c|c|c|c|c|c|c|c|}
\hline 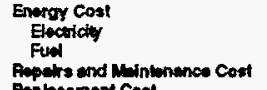 & $\begin{array}{r}50.00 \\
\$ 86,461.24 \\
\$ 5,150.10\end{array}$ & $\begin{array}{r}50.00 \\
\$ 740.04 \\
\$ 006.64\end{array}$ & $\begin{array}{c}50.00 \\
570.40 \\
s \$ 22.40\end{array}$ & $\begin{array}{r}\$ 0.00 \\
\$ 414.400 \\
\$ 400.50\end{array}$ & $\begin{array}{l}\$ 0.00 \\
\$ 05135 \\
\$ 670.77\end{array}$ & $\begin{array}{l}\$ 0.000 \\
\$ 200608 \\
\$ 710.036\end{array}$ & $\begin{array}{l}\$ 0.00 \\
\$ 020.70 \\
\$ 7762.33\end{array}$ & $\begin{array}{r}\$ 0.00 \\
\$ 071.63 \\
\$ 775.73\end{array}$ & $\begin{array}{r}\$ 0.00 \\
\$ 1,1015.25 \\
\$ \$ 10.24\end{array}$ & $\begin{array}{r}\$ 0.00 \\
\$ 1,000.94 \\
\$ \$ 47.12\end{array}$ & $\begin{array}{r}\$ 0.00 \\
\$ 1,100.64 \\
\$ 005.24\end{array}$ & 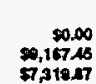 \\
\hline 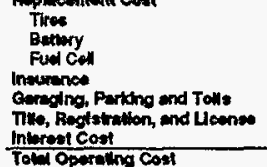 & 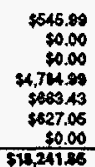 & 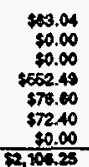 & 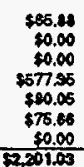 & 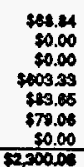 & 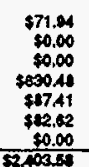 & 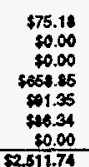 & 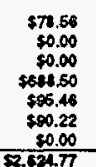 & 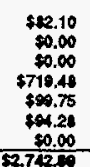 & 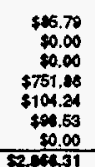 & 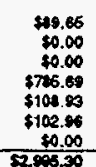 & 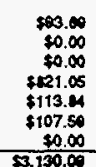 & 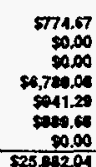 \\
\hline
\end{tabular}

Salvego Value

Tom operaing cost

מ.心

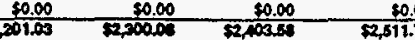

$\$ 0.00 \quad 20.00$

Environmontal costs

$33,775.67-\$ 17,739.00$

$5201.03 \quad \$ 230000 \quad 5200358$

प1.318.13

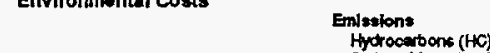

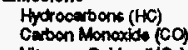

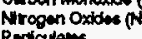

Sulter Dtoxide

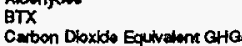

Tom Entason con

\begin{tabular}{|c|c|}
\hline 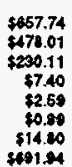 & 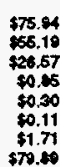 \\
\hline
\end{tabular}

\begin{tabular}{|c|c|c|c|c|c|c|c|c|c|}
\hline 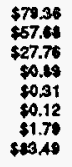 & 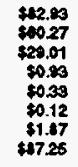 & 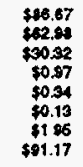 & 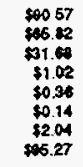 & 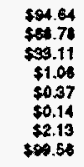 & 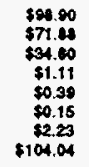 & 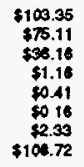 & 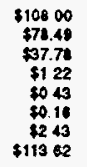 & $\begin{array}{r}\$ 112.26 \\
\$ \$ 2.02 \\
\$ 29.48 \\
\$ 1.27 \\
\$ 0.44 \\
\$ 0.17 \\
\$ 12.44 \\
\$ 110.73\end{array}$ & 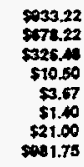 \\
\hline 10 & $\$ 262.77$ & \$2724,4 & 52010 & 502000 & $\approx \mathbf{9 1 3 . 2 0}$ & $\$ 327,30$ & $\sqrt{42.12}$ & 5367.62 & $52,056.24$ \\
\hline & $2,562 \pi$ & $52,070.12$ & $20,202.00$ & $8,924,57$ & $3,058.11$ & $3,193.70$ & $83,337,42$ & $53,288.06$ & $34,272,37$ \\
\hline
\end{tabular}

TOTALLIFECYCLECOST

$\$ 35,059.25 \quad 917,200.47$ 


\section{LIFE CYCLE COST MODEL INPUT MODULE}

Caso Number:

Basic Vehicle Configuration

Technology Options

Type of Vohicle

Power System

Type of ICE

Typo of Fuei Cell

Type of Fuel

Type of Battery Propulsion

Type of Motor/Controller

Type of Transmission

Status of Tochnology

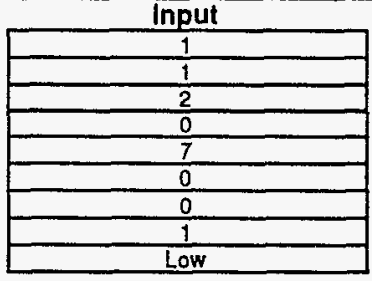

Option:

Conventional Auto

ICE

Compression Ignition

None

Reformulated Diesel

None

None

Automatic

Low
F

Options

$1-8$
$1-3$

$0-2$

$0, A-C: 1-10$

$0-3$

$1-2$

Low/High

Vohicle Physical Characteristics

Conventional Auto

Passenger Capacity $(2,4,5,6+, 10+)$

Tost Woight (kg)

Curb Woight (kg)

Base Vehiclo Woight (kg)

Accessories (kg)

Vehicle Frontal Area (sq. m)

Basic Material Salvage Value $(\$ / \mathrm{kg})$

Life of Vehicle (yr)

Distance Travoled (km/yr)

Lifo Cyclo Distanco Travoled $(\mathrm{km})$

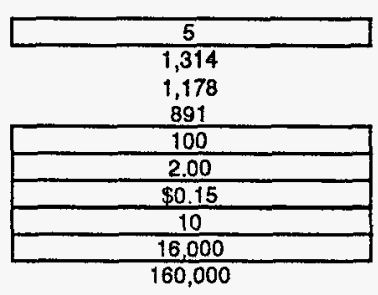

Vehicle Performance Characteristics

Acceleration to $88 \mathrm{Km} / \mathrm{h}$ (s)

Top Speed $(\mathrm{km} / \mathrm{h})$

Gradability (\%)

Rolling Friction Coefficient $(\mathbf{k m} / \mathbf{k m})$

Aerodynamic Drag Coefficient

Peak Power: (kW)

Driving Schedule

Battery Power-to-Energy Ratio

Rangs (km)

Full Cycles per year

Partial Cyclos per year

\begin{tabular}{c|c|}
\hline 20 \\
110 \\
7 \\
0.010 \\
0.320 \\
\hline 30.00 \\
\hline Mod. FUDS \\
NA \\
400 \\
40 \\
355
\end{tabular}

Propulsion System Characteristics Power System

TCE:

Engine Power (kW)

Specific Power (kW/kg)

Specitic Cost (\$/kW)

Engine Weight (kg)

Fuel Efficiency: $(\mathrm{km} / \mathrm{l})$ gasoline oquiv (mpg)

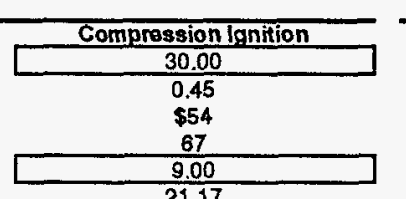

Energy Source

Aolormulated Diesel

Fuel Cost (\$/l)

Fuel Efficiency $(/ \mathrm{km})$

Electricity Cost (\$/kWhr)

Fuol Efficiency (kWhr/km)

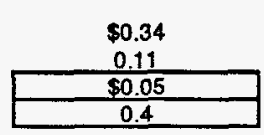

Drive Train

Motor

Poak Power (kW)

Specific Power (kW/kg)

Weight (kg)

Power Rating (kW)

Specific Power [Continuous] (kW/kg)

Power Density [Continuous] (kW/I)

Efficioncy

Specific Cost $(\$ / k W)$

Woight $(\mathrm{kg})$

Fuel Efficiency: (km/l)

$$
\text { (mpg) }
$$

Battory:

Power Rating (kW)

Energy Capacity (kWh)

Specific Energy (Wh/kg)

Specific Power ( $W / \mathrm{kg})$

Efficiency (\%)

Cycle Lifo

Specific Cost $(\$ / \mathrm{kW})$

Woight (kg)

$80 \%$ Full Range Discharge $(\mathrm{km})$

Number of Replacements

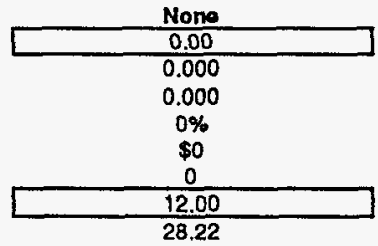

Controller

Poak Power (kW)

Specific Power (kW/kg)

Woight $(\mathrm{kg})$

Transmission Syatem

Peak Power (kW)

Specific Power (kW/kg)

Woight (kg)

None

0.00

0

Drive Train Efficiency (\%)

None

0
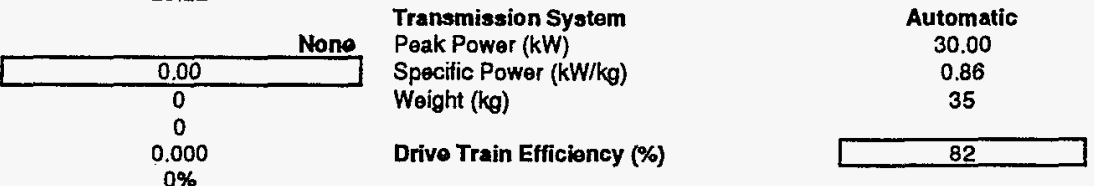

Fuel Tank

Material

Specific Weight (gm/cc)

Spocific Cost $(\mathbf{S} / \mathrm{kg})$

Tank Capacity: (I)

Tank Weight (w/ Fuel) (kg)

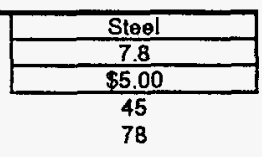

Cost of Capital (\%/100)

Loan Term (yr)

Down payment $(\%)$

\begin{tabular}{|c|}
\hline 0.08 \\
\hline 0 \\
\hline $100 \%$ \\
\hline
\end{tabular}

Present Value Discount Rate (\%/100)

Cost Escalationflnflation] Rate (\%/100)

\begin{tabular}{|c|}
\hline 1992 \\
\hline 0.080 \\
\hline 0.045 \\
\hline
\end{tabular}

(\%)

End of Inpur Soction 


\section{Life Cycle Cost Summary}

\section{2}

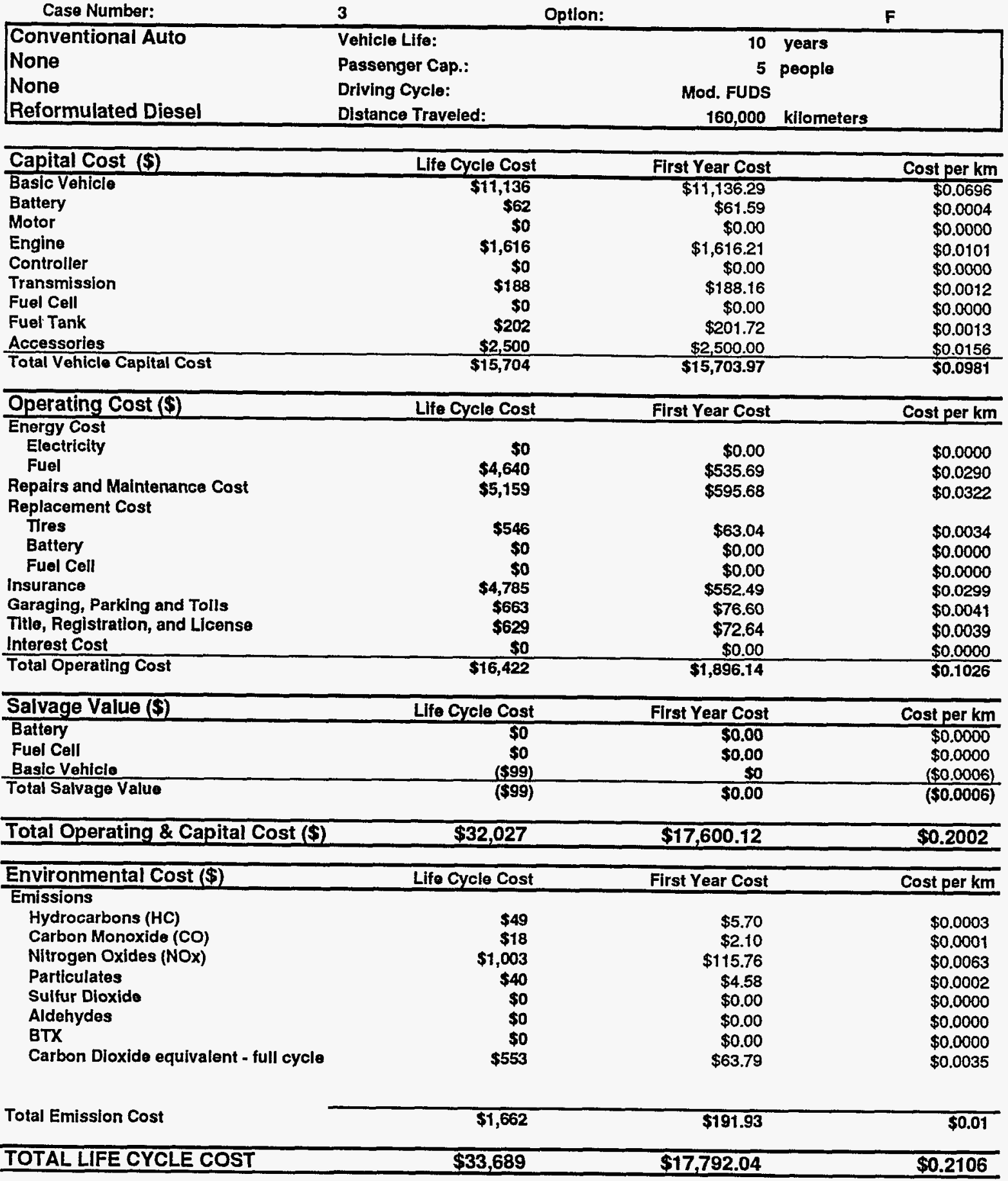


Life Cycle Cost Summary

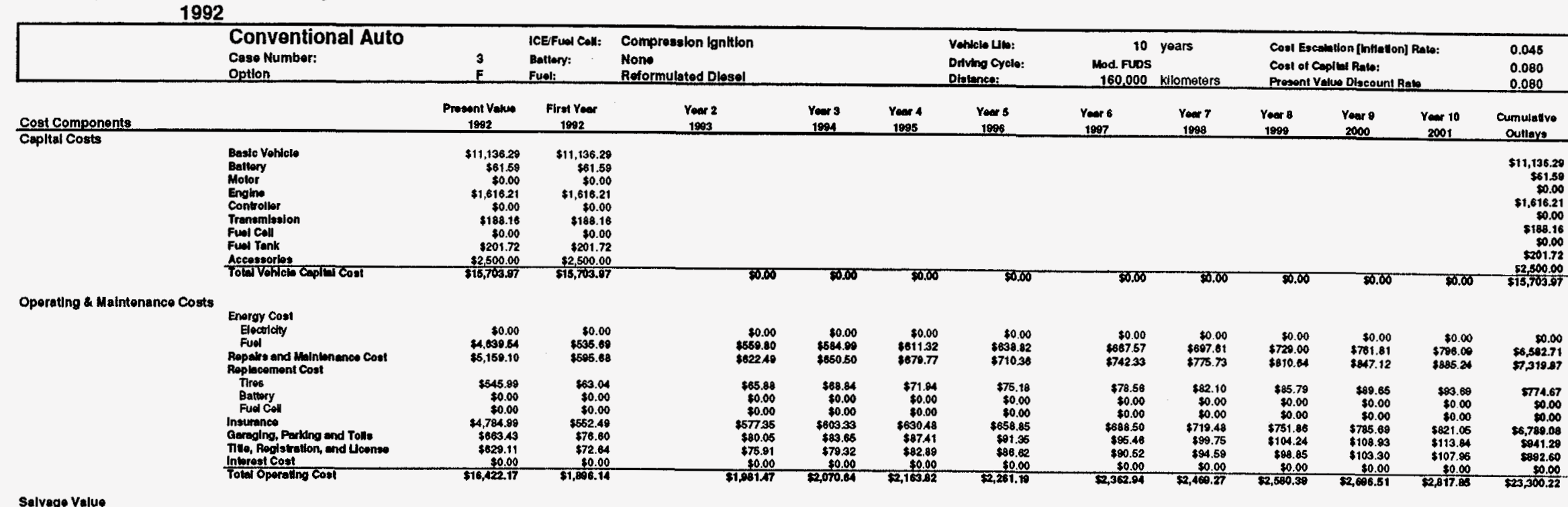

Salvege value

\begin{tabular}{|c|c|c|c|c|c|c|c|c|c|c|c|c|c|}
\hline & 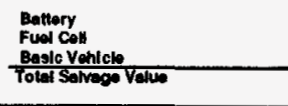 & 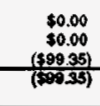 & $\$ 0.00$ & 50.00 & $\$ 0.00$ & 50.00 & 50.00 & 80.00 & $\$ 0.00$ & $\$ 0.00$ & $\$ 0.00$ & $\begin{array}{r}\$ 0.00 \\
80.00 \\
(\$ 19.80) \\
(\$ 128.60)\end{array}$ & $\begin{array}{r}\$ 0.00 \\
\$ 0.00 \\
-(\$ 190.60) \\
(\$ 198.60)\end{array}$ \\
\hline Ioteloperating capital Cost & & $\$ 22.026 .78$ & $\$ 17,000.12$ & $\$ 1,891 / 17$ & 2070.64 & 82.163 .82 & $82,261.18$ & $78,362.94$ & $\mathbf{8 . 6 6 9 . 2 7}$ & $\$ 2,580.39$ & 80.06 .51 & $2,619.26$ & $\$ 88.905 .60$ \\
\hline Environmontai Costs & 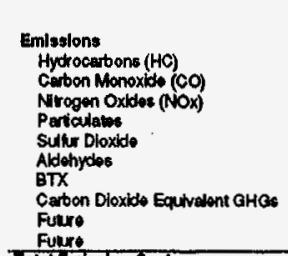 & 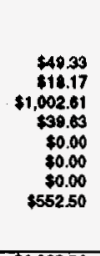 & $\begin{array}{r}\$ 5.70 \\
42.10 \\
\$ 115.70 \\
4.58 \\
40.58 \\
30.00 \\
30.00 \\
\$ 33.7 .7\end{array}$ & 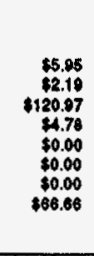 & $\begin{array}{r}\$ 8.22 \\
6220 \\
\$ 120.42 \\
\$ \$ 5.00 \\
\$ 50.00 \\
80.00 \\
\$ \$ 0.00 \\
\$ 89.86\end{array}$ & 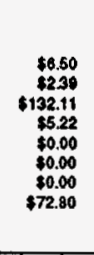 & 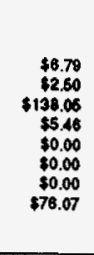 & 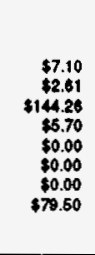 & 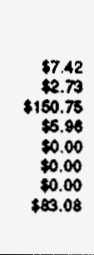 & 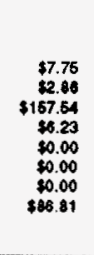 & $\begin{array}{r}\$ 8.10 \\
\$ 2.89 \\
\$ \$ 10.63 \\
\$ 6.52 \\
\$ 0.00 \\
\$ 0.00 \\
\$ 0.00 \\
\$ 90.72\end{array}$ & 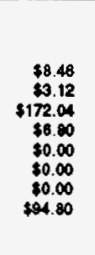 & 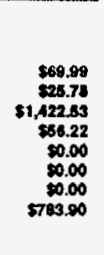 \\
\hline & Tod Emberon cont & $31,662.24$ & $\$ 191.83$ & 20080 & 526050 & 5218.02 & $528 \overline{86}$ & 5239.18 & 520.04 & 8261.19 & $\$ 272.94$ & 8235.22 & $\sqrt{2.356 .43}$ \\
\hline TOTAL LAFE CYCLE COST & & $\$ 3,60903$ & $517,722.04$ & $82,182.03$ & $82,200.23$ & 5033204 & $\$ 2,00,06$ & $2,002.12$ & $52,719.21$ & $82,341.58$ & $82,069.45$ & \$2,801.43 & M1,164.03 \\
\hline
\end{tabular}




\section{LIFE CYCLE COST MODEL INPUT MODULE}

Case Number:

Option:

G

Basic Vehicle Configuration

Technology Options

Type of Vehicle

Power System

Type of ICE

Type of Fuel Cell

Type of Fuel

Type of Battery Propuision

Type of Motor/Controller

Type of Transmission

Status of Technology

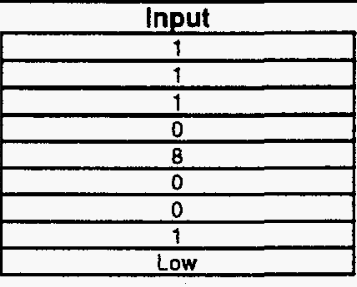

Conventional Auto

ICE

Spark Ignition

None

$M 85$

None

None

Automatic

Low

Options
$1-8$
$1-3$
$0-2$
$0-2$
$0-8$
$0, A-C: 1-10$
$0-3$
$1-2$
Low/High

Vehicle Physical Characteristics

Conventional Auto

Passenger Capacity $(2,4,5,6+, 10+)$

Test Weight (kg)

Curb Weight $(\mathrm{kg})$

Base Vehicle Weight $(\mathrm{kg})$

Accessories (kg)

Vehicte Frontal Area (sq. m)

Basic Material Salvage Value (\$/kg)

Life of Vehicle (yr)

Distance Traveled (km/yr)

Life Cycle Distanco Traveled (km)

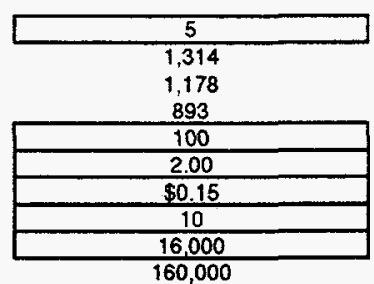

Vehicle Performance Characteristics

Acceleration to $88 \mathrm{Km} / \mathrm{h}(\mathrm{s})$

Top Speed $(\mathrm{km} / \mathrm{h})$

Gradability (\%)

Polling Friction Coefficient $(\mathrm{km} / \mathrm{km})$

Aerodynamic Drag Coefficient

Peak Power: (kW)

Driving Schedule

Battery Power-to-Energy Ratio

Range (km)

Full Cycles per year

Partial Cycles per year

\begin{tabular}{c}
20 \\
110 \\
7 \\
0.010 \\
0.320 \\
\hline 30.00 \\
\hline
\end{tabular}

30.00

NA

400

400

355

Propulsion System Characteristic

POW:

Engine Power (kW)

Specific Power ( $(\mathrm{W} / \mathrm{kg})$

Specific Cost ( $\$ \mathbf{k W})$

Engine Weight $(\mathrm{kg})$

Fuel Efficiency: $(\mathrm{km} /)$ gasoline equiv

$$
\text { (mpg) }
$$

Fuel Cell:

Power Rating (kW)

Specitic Power [Continuous] (kW/kg)

Power Density [Continuous] (kW/I)

Efficiency

Specific Cost (\$/kW)

Weight (kg)

Fuel Efficiency: $(\mathrm{km} /)$

(mpg)

Battery:

Power Rating ( $k w$ )

Energy Capacity (kWh)

Specific Energy (Wh/kg)

Specific Power (W/kg)

Efficiency (\%)

Cycle Life

Specific Cost $(\$ / \mathrm{kW})$

Weight (kg)

80\% Full Range Discharge (km)

Number of Replacements

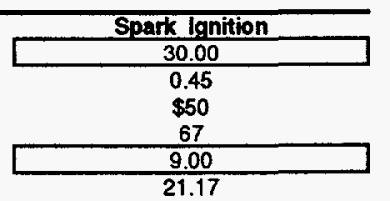

\section{Enercy Source}

$M 85$

Fuel Cost (\$/)

Fuel Efficiency ( $(\mathbf{k m})$

Electricity Cost (\$/kWhr)

Fuel Efficiency (kWhr/km)

0.11

Drive Train

Drive Tra

Poak Power (kW)

Specific Power (kW/kg)

Woight (kg)

Controller

Peak Power (kW)

Specific Power (kW/kg)

Woight (kg)

Tranemission System

Peak Power (kW)

Specific Power ( $\mathrm{kW} / \mathrm{kg})$

Weight (kg)

Drive Train Efficiency (\%)

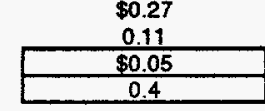

Fuet Tank

Material

Specific Weight (gm/cc)

Specific Cost $(\$ / \mathrm{kg})$

Tank Capacity: (I)

Tank Weight (w/ Fuel) (kg)

None

0.00

0

None

0.00

Economic Analysis Factors

Analysis base year

Present Value Discount Rate $(\% / 100)$

Cost Escalation[Inflation] Rate (\%/100)

\begin{tabular}{|c|}
\hline 1992 \\
\hline 0.080 \\
\hline 0.045 \\
\hline
\end{tabular}

Cost of Capital (\%100)

Loan Term (yr)

Down payment (\%)

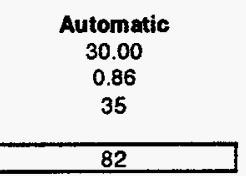

End of Inout Soction

Engineering Systems Management, Inc. 


\section{Life Cycle Cost Summary}

1992

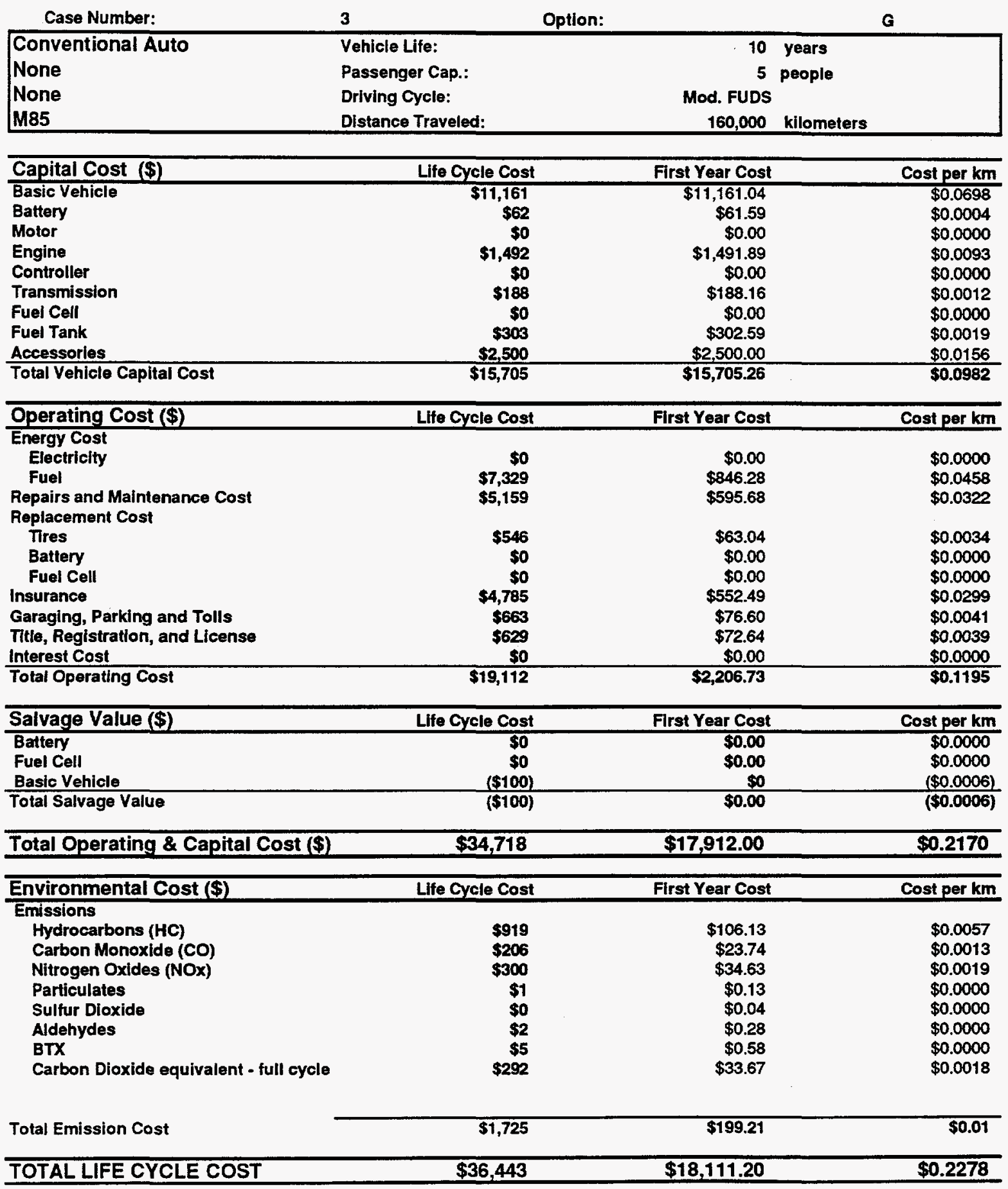


Life Cycle Cost Summary

\begin{tabular}{|c|c|c|c|c|c|c|c|c|c|c|c|c|c|c|}
\hline \multirow[b]{2}{*}{ Cost Components } & \multirow[t]{2}{*}{$\begin{array}{l}\text { Conventional Auto } \\
\text { Case Numbor: } \\
\text { optlon }\end{array}$} & \multirow{2}{*}{$\begin{array}{c}3 \\
a \\
\begin{array}{c}\text { Prosent Valluos } \\
1992\end{array}\end{array}$} & \multirow{2}{*}{ 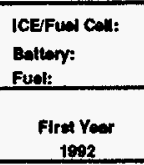 } & \multicolumn{2}{|l|}{$\begin{array}{l}\text { Spark lgnittion } \\
\text { Nono } \\
\text { MB8 }\end{array}$} & \multirow[b]{2}{*}{$\begin{array}{l}\text { Yor } 3 \\
1894 \\
\end{array}$} & \multirow[b]{2}{*}{$\begin{array}{r}\text { Year } 4 \\
1898 \\
\end{array}$} & \multirow{2}{*}{ 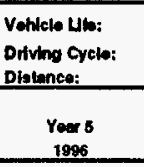 } & \multirow{2}{*}{$\begin{array}{c}10 \\
\begin{array}{r}10 \\
\text { Mod. fuos } \\
160,000\end{array} \\
\begin{array}{c}\text { Yoarc } \\
1927\end{array} \\
\end{array}$} & \multirow{2}{*}{$\begin{array}{c}\text { years } \\
\text { klitometers } \\
\begin{array}{c}\text { Your } 7 \\
1998\end{array} \\
\end{array}$} & \multicolumn{3}{|c|}{ 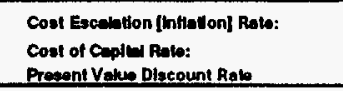 } & \multirow{2}{*}{\begin{tabular}{|c|}
0.045 \\
0.080 \\
0.080 \\
$\begin{array}{c}\text { cumulatve } \\
\text { Quttars }\end{array}$ \\
\end{tabular}} \\
\hline & & & & $\begin{array}{r}\text { Your } 2 \\
1003\end{array}$ & & & & & & & $\begin{array}{l}\text { Your } 8 \\
1009\end{array}$ & $\begin{array}{l}\text { rome } 9 \\
2000\end{array}$ & $\begin{array}{l}\mathrm{Y} \times 10 \\
2001\end{array}$ & \\
\hline Capital Costs & 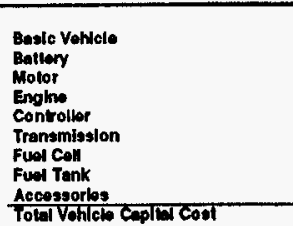 & 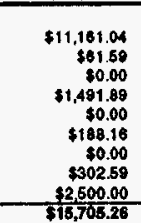 & $\begin{array}{r}\$ 11.161 .04 \\
\$ \$ 1.60 \\
\$ 0.00 \\
\$ 1,401.89 \\
\$ 0.00 \\
\$ 188.16 \\
\$ 0.00 \\
\$ 302.59 \\
\$ 2,500.00 \\
\$ \$ 16,706.28\end{array}$ & & $\$ 00$ & $\$ 0.00$ & $\$ 00$ & $\$ 000$ & 30.06 & 0.00 & $\$ 0.0$ & 30.06 & 30.00 & 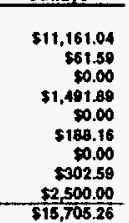 \\
\hline Operating \& Malntenance Costs & 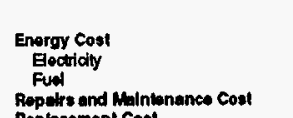 & $\begin{array}{r}\$ 0.00 \\
\$ 7,329.47 \\
\$ 5,169.10\end{array}$ & $\begin{array}{r}\$ 0.00 \\
586.28 \\
+2096.68\end{array}$ & & 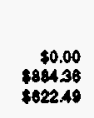 & $\begin{array}{r}\$ 0.00 \\
\$ 02.16 \\
\$ 600.50\end{array}$ & $\begin{array}{r}\$ 0.00 \\
\$ \$ 865.75 \\
\$ 878.7\end{array}$ & $\begin{array}{r}\$ 0.00 \\
\$ 1,009.20 \\
\$ 710.36\end{array}$ & $\begin{array}{r}\$ 0.00 \\
\$ 1,054.62 \\
\$ 742.33\end{array}$ & $\begin{array}{r}\$ 0.00 \\
+1,102.08 \\
\$ \$ 772.73\end{array}$ & $\begin{array}{r}\$ 0.00 \\
\$ 1,151.67 \\
\$ \$ 1910.64\end{array}$ & $\begin{array}{r}\$ 0.00 \\
\$ 1,203.49 \\
, \quad \$ 47.12\end{array}$ & $\begin{array}{r}\$ 0.00 \\
\$ 1.257 .05 \\
\$ 8855.24\end{array}$ & $\begin{array}{r}\$ 50.00 \\
510,399.26 \\
\nabla, 319,27\end{array}$ \\
\hline & 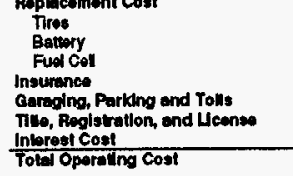 & $\begin{array}{r}\$ 545.99 \\
\$ 0.00 \\
\$ 0.00 \\
\$ 4.744 .99 \\
\$ 689.43 \\
\$ 282.15 \\
\$ 0.00 \\
\$ 19,112.13\end{array}$ & $\begin{array}{r}\$ 63.04 \\
\$ 0.00 \\
40.00 \\
\$ 562.49 \\
\$ 78.60 \\
872.64 \\
\$ 0.00 \\
52,206.73\end{array}$ & & $\begin{array}{r}\$ 65.96 \\
\$ 0.00 \\
\$ 0.00 \\
\$ 57735 \\
\$ 80.05 \\
\$ 75.91 \\
\$ 0.00 \\
20,06.04\end{array}$ & $\begin{array}{r}\$ 68.94 \\
\$ 0.00 \\
\$ 0.00 \\
\$ 60.03 \\
\$ 83.39 \\
\$ 70.65 \\
80.00 \\
52,009.81\end{array}$ & $\begin{array}{r}\$ 71.84 \\
\$ 0.00 \\
\$ 0.00 \\
\$ 630.48 \\
\$ \$ 8.41 \\
\$ 82.90 \\
\$ 50.00 \\
25,518.25\end{array}$ & $\begin{array}{r}\$ 75.18 \\
\$ 0.00 \\
\$ 0.00 \\
\$ 658.85 \\
\$ 91.35 \\
\$ 96.63 \\
\$ 0.00 \\
\$ 2.691 .57\end{array}$ & 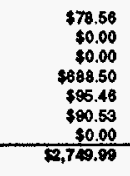 & $\begin{array}{r}\$ 82.10 \\
\$ 0.00 \\
\$ 0.00 \\
\$ 719.48 \\
\$ 89.75 \\
\$ 94.60 \\
\$ 0.00 \\
\$ 2,873.74\end{array}$ & 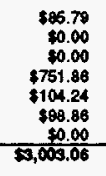 & 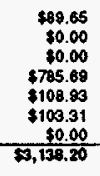 & $\begin{array}{r}\$ 99.09 \\
\$ 0.00 \\
\$ 0.00 \\
\$ 821.05 \\
3113.84 \\
3107.06 \\
\$ 0.00 \\
\$ 3,270.12\end{array}$ & $\begin{array}{r}\$ 77.67 \\
\$ 0.00 \\
\$ 0.00 \\
\$ 6,789.08 \\
\$ 8911.29 \\
5992.68 \\
\$ 0.00 \\
\$ \$ 27,116.02\end{array}$ \\
\hline Salvage Value & $\begin{array}{l}\text { Bamory } \\
\text { Puat Call } \\
\text { Basid Velices }\end{array}$ & 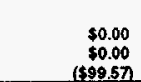 & & & & & & & & & & & $\begin{array}{r}\$ 0.00 \\
\$ 0.00 \\
(\$ 199.04)\end{array}$ & $\begin{array}{r}\$ 0.00 \\
\$ 0.00 \\
(\$ 109.04)\end{array}$ \\
\hline & 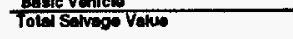 & 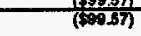 & $\$ 000$ & & 90.00 & 50.00 & 5000 & $\$ 0.00$ & $\$ 0.00$ & $\$ 0.00$ & $\$ 0.00$ & $\$ 0.00$ & (5199.04) & (5190.04) \\
\hline Iotel Operating \& Capittal Cost & & 534,71782 & $97,912.00$ & & 82306.04 & 240081 & 8.518 .25 & $\$ 2.031 .57$ & 8.749 .90 & $\$ 2.873,74$ & $90,003.08$ & 0.138 .20 & $\$ 0,080.38$ & $\$ \$ 2,623.04$ \\
\hline Environmental Costs & 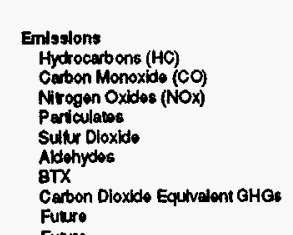 & 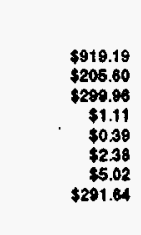 & 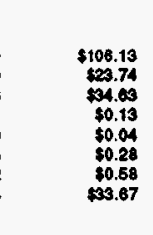 & & 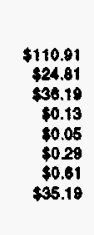 & $\begin{array}{c}\$ 115.90 \\
\$ 25.92 \\
\$ 37.82 \\
\$ 8.14 \\
\$ 30.05 \\
\$ 0.30 \\
\$ 0.03 \\
\$ 38.77\end{array}$ & 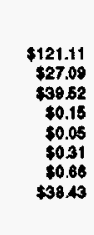 & 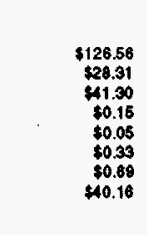 & $\begin{array}{l}\$ 132.26 \\
\$ 22.58 \\
43.16 \\
\$ 30.16 \\
\$ 0.06 \\
\$ 0.06 \\
\$ 0.74 \\
\$ 0.72 \\
41.98\end{array}$ & $\begin{array}{l}\$ 138.21 \\
\$ 0.91 \\
45.10 \\
\$ 5.17 \\
\$ 0.17 \\
\$ 0.06 \\
\$ 0.36 \\
\$ 0.76 \\
\$ 43.25\end{array}$ & 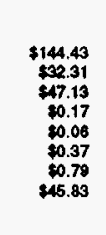 & $\begin{array}{l}\$ 150.93 \\
\$ 30.78 \\
40.25 \\
\$ 0.18 \\
\$ 0.06 \\
\$ 0.06 \\
\$ 50.38 \\
\$ 0.62 \\
47.89\end{array}$ & 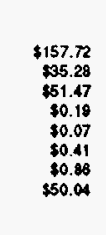 & $\begin{array}{r}\$ 1.304 .17 \\
5291.71 \\
\$ 425.59 \\
\$ 1.57 \\
50.53 \\
\$ 3.34 \\
\$ 7.12 \\
\$ 113.79\end{array}$ \\
\hline & 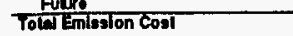 & $31,723.20$ & 310.21 & & $\$ 208.17$ & 517.54 & $\$ 22733$ & $\$ 237.56$ & 240.25 & $\$ 239.42$ & 271.00 & 5203.20 & $\$ 20.94$ & $\$ 2,447.90$ \\
\hline TOTAL LIFE CYCLE COST & & $936,43.12$ & $\$ 18,111.20$ & & 82.516 .21 & $82,627,35$ & $\$ 2,725.38$ & $22,869.13$ & $2,990.24$ & $\$ 2,133,16$ & $\$ 0,27,15$ & $\$ 3,121,40$ & $\$ 3,376,42$ & $345,070,84$ \\
\hline
\end{tabular}




\section{LIFE CYCLE COST MODEL INPUT MODULE}

Basic Vehicle Configuration

\begin{tabular}{l|l|}
\hline Technology Options \\
Type of Vehicle \\
Power System \\
Type of ICE \\
Type of Fuel Cell \\
Type of Fuel \\
Type of Battery Propulsion \\
Type of Motor/Controller \\
Type of Transmission \\
Status of Technology
\end{tabular}

Status of Technology

\section{Vehicle Physical Characteristics}

Electric Auto

Passenger Capacity $(2,4,5,6+, 10+)$

Test Weight $(\mathrm{kg})$

Curb Weight $(\mathrm{kg})$

Base Vehicte Woight $(\mathrm{kg})$

Accessories (kg)

Vehicle Frontal Area (sq. m)

Basic Material Salvage Value (\$/kg)

Life of Vehicle (yr)

Distance Traveled (km/yr)

Life Cyde Distance Traveled (km)

\begin{tabular}{|c|}
\hline 5 \\
\hline 500 \\
1,500 \\
1,280 \\
\hline 100 \\
\hline 2.00 \\
\hline$\$ 0.15$ \\
\hline 10 \\
\hline 16,000 \\
\hline 160,000 \\
\hline
\end{tabular}

Option:

A

Electric Auto

Battery EV

None

Reformulated Gasoline

Lead-Acid

DC Brushless

Automatic

High

Vehicle Performance Characteristics

Accoleration to $8 B \mathrm{Km} / \mathrm{h}(\mathrm{s})$

Top Speed (km/h)

Gradability (\%)

Rolling Friction Coefficient (km/km)

Aorodynamic Drag Coetlicient

Peak Power: (kW)

Driving Schedule

Battery Power-to-Energy Ratio

Pange (km)

Full Cycles per year

Partial Cycles per year

Options

$1-8$

$1-3$

$0-2$

$0-2$

0-8

$0, A-C: 1-10$

$0-3$

1-2

Low/High

20

110

010

0.320

Mod. FUDS

0.75

200

80

355

Propulsion System Characteristics

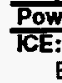

CE: Power System

Engine Power (kW)

Specific Power (kW/kg)

Specific Cost (\$/kW)

Engine Weight $(\mathrm{kg})$

Fuel Efficiency: (km/) gasoline equiv

$$
\text { (mpg) }
$$

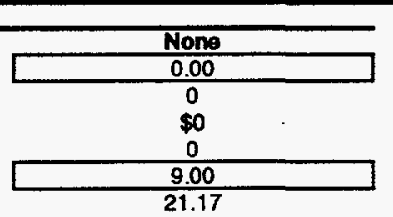

Fuel Cell:

Power Rating (kW)

Specific Power [Continuous] (kW/kg)

Power Density [Continuous] (kW/)

Efficiency

Specific Cost $(\$ / k W)$

Weight (kg)

Fuel Efficiency: (km/l)

$$
\text { (mpg) }
$$

Battery:

Power Rating (kW)

Energy Capacity (kWh)

Specific Energy (Wh/kg)

Specific Power (W/kg)

Efficiency $(\%)$

Cycle Life

Specific Cost (\$/kW)

Weight (kg)

B0\% Full Range Discharge (km)

Number of Replacements

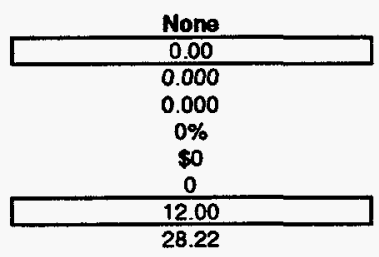

Energy Source

Elactricity

Fuel Cost (\$N)

Fuel Efficiency (Vkm)

Electricity Cost ( $\$ / \mathrm{kWhr})$

Fuel Efticiency (kWhr/km)

Drive Train

Motor

Peak Power (kW)

Specific Power (kW/kg)

Weight (kg)

Controllar

Peak Power (kW)

Specific Power (kW/kg)

Weight (kg)

Transmission System

Peak Power (kW)

Specific Power (kW/kg)

Weight (kg)

Drive Train Efficiency (\%)

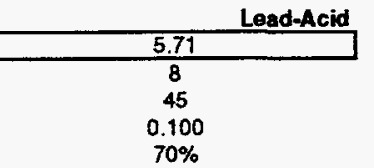

Fuel Tank

Material

Specific Weight (gm/cc)

Specific Cost $(\$ / \mathrm{kg})$

Tank Capacity: (I)

Tank Weight (w/ Fuel) (kg)

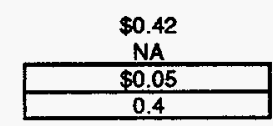

0.4

Economic Analysis Factors

Analysis base year

Present Value Discount Rate $(\% / 100)$

Cost Escalation[inflation] Rate $(\% 100)$

\begin{tabular}{|c|}
\hline 1992 \\
\hline 0.080 \\
\hline 0.045 \\
\hline
\end{tabular}

Cost of Capital (\%/100)

Loan Term (yr)

Down payment $(\%)$

DC Brushlos:

15.88

0.64

25

DC Brushles:

15.88

0.88

18

15.88

18

82

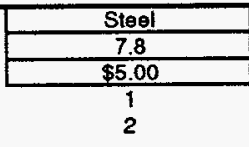

End of Input Soction 


\section{Life Cycle Cost Summary}

\section{2}

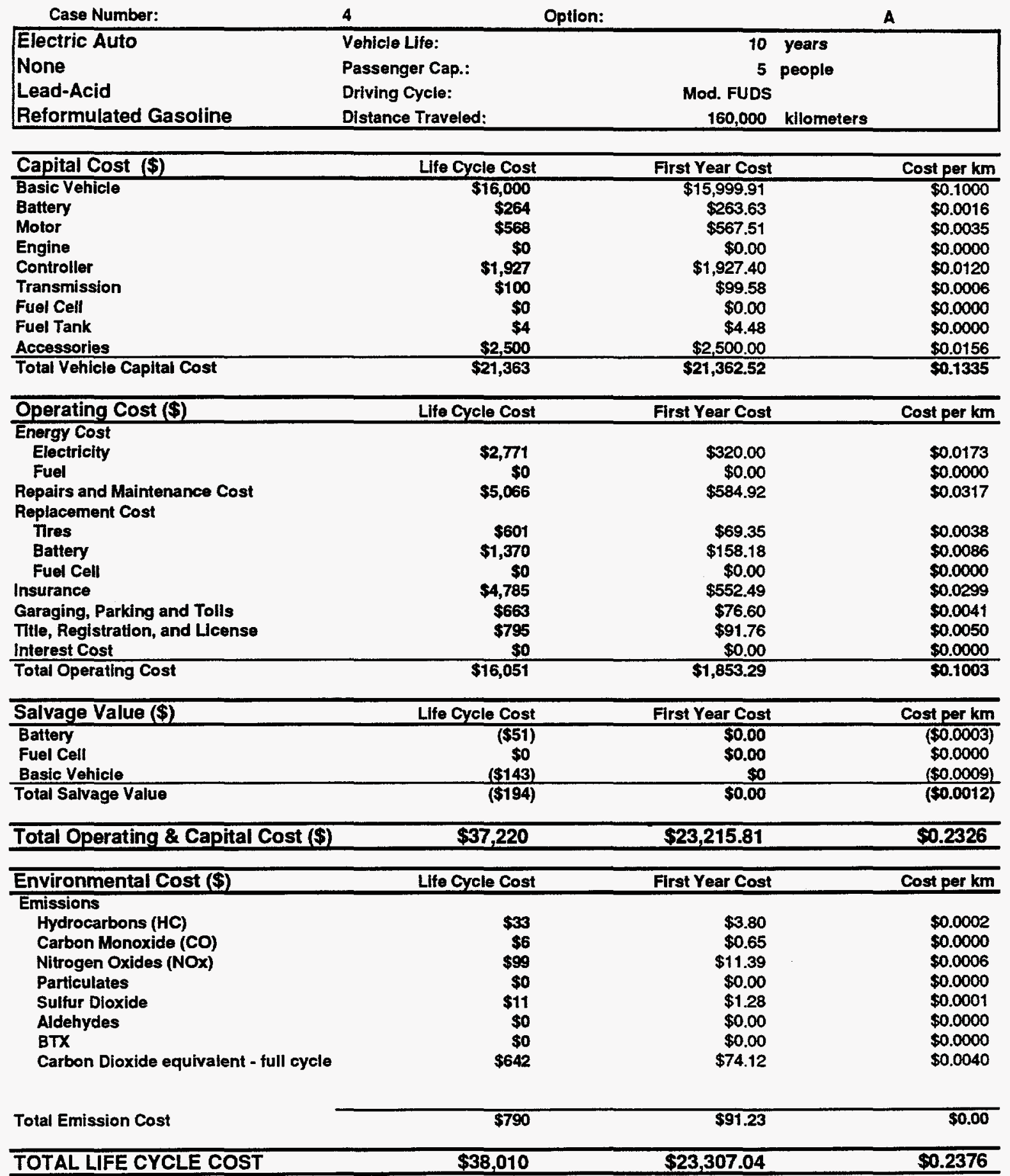


Life Cycle Cost Summary

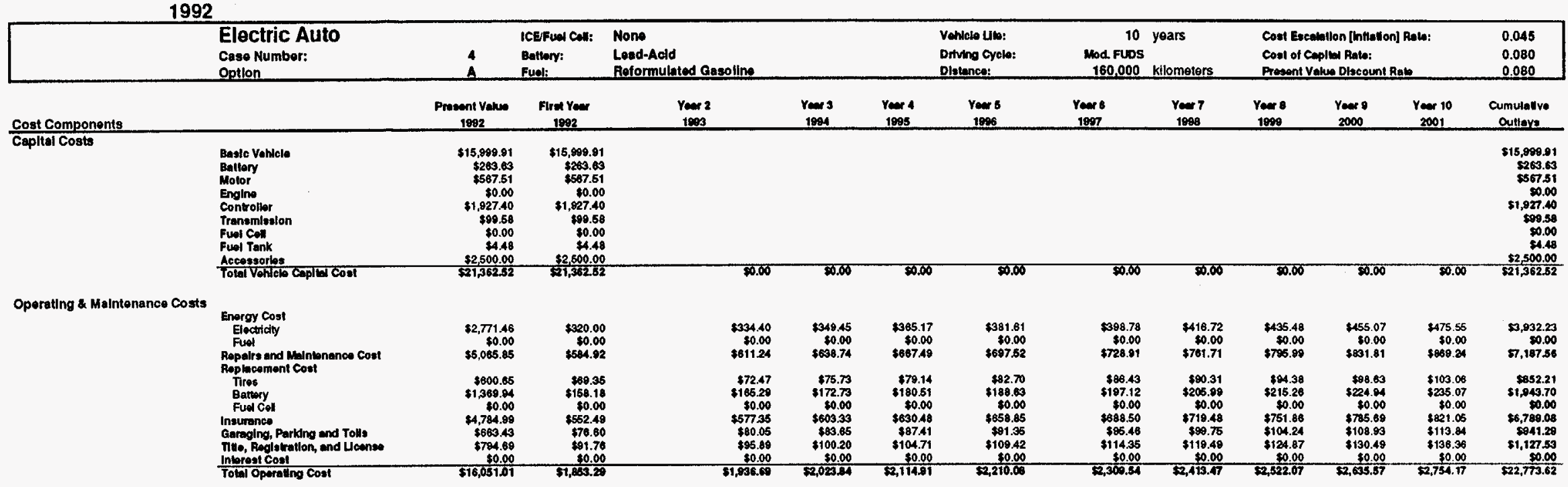

Salvago Value

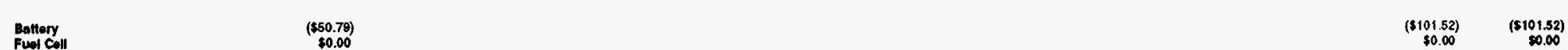

\begin{tabular}{|c|c|c|c|c|c|c|c|c|c|c|c|c|c|}
\hline \multirow[t]{2}{*}{ Salvago Value } & \multirow{2}{*}{ 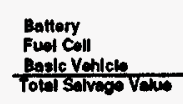 } & \multirow{2}{*}{$\begin{array}{r}(\$ 50.79) \\
50.00 \\
-(1142.74) \\
(5103.3252)\end{array}$} & \multirow[b]{2}{*}{80.00} & \multirow[b]{2}{*}{80.00} & \multirow[b]{2}{*}{00.00} & \multirow[b]{2}{*}{80.00} & \multirow[b]{2}{*}{50.00} & \multirow[b]{2}{*}{$\$ 0.00$} & \multirow[b]{2}{*}{$\$ 0.00$} & \multirow[b]{2}{*}{50.00} & & \multirow{2}{*}{$\begin{array}{l}(\$ 101.52) \\
\$ 0.00 \\
-(\$ 2.33) \\
(\$ \$ 2066.85)\end{array}$} & \multirow{2}{*}{ 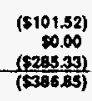 } \\
\hline & & & & & & & & & & & 00.00 & & \\
\hline Tota Operating & & 537220.00 & $92,218.81$ & $\$ 1,936.69$ & 2023.84 & 22,11491 & $\$ 2,210.08$ & $8,300.54$ & $92,418.47$ & $\$ 2.522 .07$ & 82.035 .57 & 52.367 .32 & 749.28 \\
\hline
\end{tabular}

Environmental costs

\begin{tabular}{|c|c|c|c|c|c|c|c|c|c|c|c|}
\hline 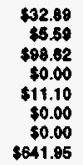 & 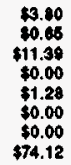 & $\begin{array}{c}\$ 3.97 \\
\$ 4.07 \\
\$ 11.90 \\
\$ 0.00 \\
\$ \$ 3.13 \\
\$ 0.00 \\
\$ 0.00 \\
\$ 77.48\end{array}$ & $\begin{array}{c}\$ 4.15 \\
80.70 \\
812.43 \\
80.00 \\
81.40 \\
80.00 \\
80.00 \\
580.24\end{array}$ & 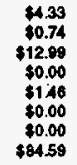 & 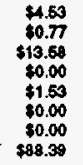 & $\begin{array}{c}\$ .73 \\
\$ 0.10 \\
\$ 11.19 \\
\$ 0.00 \\
\$ 1.00 \\
\$ 0.00 \\
\$ 50.00 \\
592.37\end{array}$ & 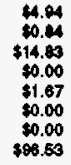 & $\begin{array}{r}\$ 5.17 \\
\$ \$ .08 \\
\$ 1.50 \\
\$ 5.00 \\
\$ \$ .174 \\
\$ \$ .00 \\
\$ \$ 0.00 \\
\$ 100.87\end{array}$ & 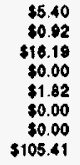 & 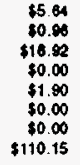 & 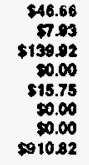 \\
\hline$\$ 790.15$ & 91.23 & $\$ 2834$ & $\$ 09.63$ & $\$ 104.11$ & 3108.90 & F्ञ13.69 & $\$ 118.81$ & $\$ 124.15$ & $\$ 128.74$ & $\$ 135.50$ & $\$ 1,121.09$ \\
\hline
\end{tabular}

TOTAL LIFE CYCLE COST

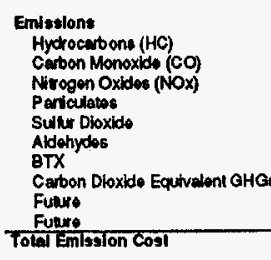

$\$ 30.010 .16 \quad 93.37 .04$

$8,032.03 \quad 8,123,17$

$82,318.38$ 


\section{LIFE CYCLE COST MODEL INPUT MODULE}

Case Number: Basic Vehicle Configuration

\begin{tabular}{l|}
\hline Technology Options \\
Type of Vehicle \\
Power System \\
Type of ICE \\
Type of Fuel Cell \\
Type of Fuel \\
Type of Battery Propulsion \\
Type of Motor/Contraller \\
Type of Transmission \\
Status of Technology
\end{tabular}

Option:

Fuel CelvBattery Auto

Fuel CeltBattery

None

PEUFC-Methanol

Methanol (M100)

Medium Performance Generic

Automatic

High

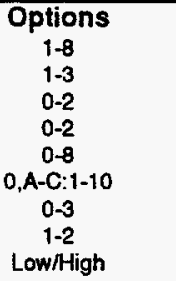

Vehicle Performance Characteristica

Acceleration to $88 \mathrm{Km} / \mathrm{h}$ (s)

Top Speed $(\mathrm{km} / \mathrm{h})$

Gradability (\%)

Rolling Friction Coefficient (km/ $/ \mathrm{km})$

Aerodynamic Drag Coefficient

Peak Power: (kW)

Driving Schedule

Battery Power-to-Energy Ratio

Range (km)

Full Cycles per year

Partial Cycles per year

\begin{tabular}{|c|}
\hline 20 \\
110 \\
7 \\
0.010 \\
0.320 \\
\hline 35.85 \\
\hline Mod. FUDS \\
0.75 \\
400 \\
40 \\
355
\end{tabular}

Distance Traveled (km/yr)

Life Cycle Distance Traveled (km)

16,000

160,000

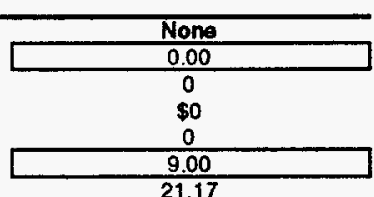

Energy Source

Mothanol (Mtoo)

Fuel Cost (\$/1)

Fuel Efficiency $(U \mathrm{~km})$

Electricity Cost (\$/kWhr)

Fuel Efficiency (kWhr/km)

Specific Cost $(\$ / \mathrm{kW})$

Engine Weight (kg)

Fuel Efficiency: (km/) gasoline equiv (mpg)

21.17

Fuel Cell:

Power Rating (kW)

Specific Power [Continuous] (kW/kg)

Power Density [Continuous] (kW/l)

Efficiency

Specific Cost (\$/kW)

Woight $(\mathrm{kg})$

Fuel Efficiency: (km/)

(mpg)

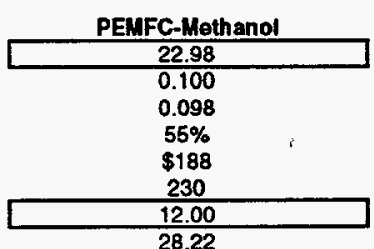

Battery:

Power Rating (kW)

Energy Capacity (kWh)

Specific Energy (Wh/kg)

Specific Power (W/kg)

Efficiency $(\%)$

Cycle Life

Specitic Cost (\$/kW)

Weight $(\mathrm{kg})$

80\% Full Range Discharge (km)

Number of Replacements

Drive Train

Potor Power (kW)

Specific Power (kW/kg)

Weight (kg)

\section{Controller}

Peak Power (kW)

Specific Power (kW/kg)

Weight (kg)

Transmission Syatem

Peak Power (kW)

Specific Power (kW/kg)

Woight (kg)

Drive Train Efficiency (\%)

$\$ 0.25$

$\$ 0.05$

0.4

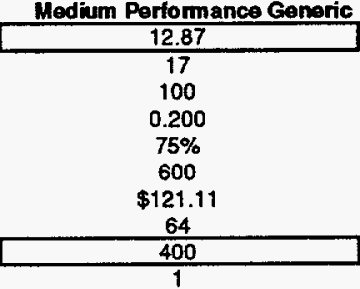

AC
35.85

35.85
0.49

Fuel Tank

Material

Specific Woight (gm/cc)

Specific Cost (\$/kg)

Tank Capacity: (I)

Tank Weight (w/ Fuel) (kg)

AC

35.85

utomatic

35.85

0.86

42

Cost of Capital (\%/t00)

Loan Term (yr)

Down payment $(\%)$

Analysis base year

Present Value Discount Rate (\%/100)

Cost Escalationilnflation] Rate (\%100)

\begin{tabular}{|c|}
\hline 1992 \\
\hline 0.080 \\
\hline 0.045 \\
\hline
\end{tabular}




\section{Life Cycle Cost Summary}

1992

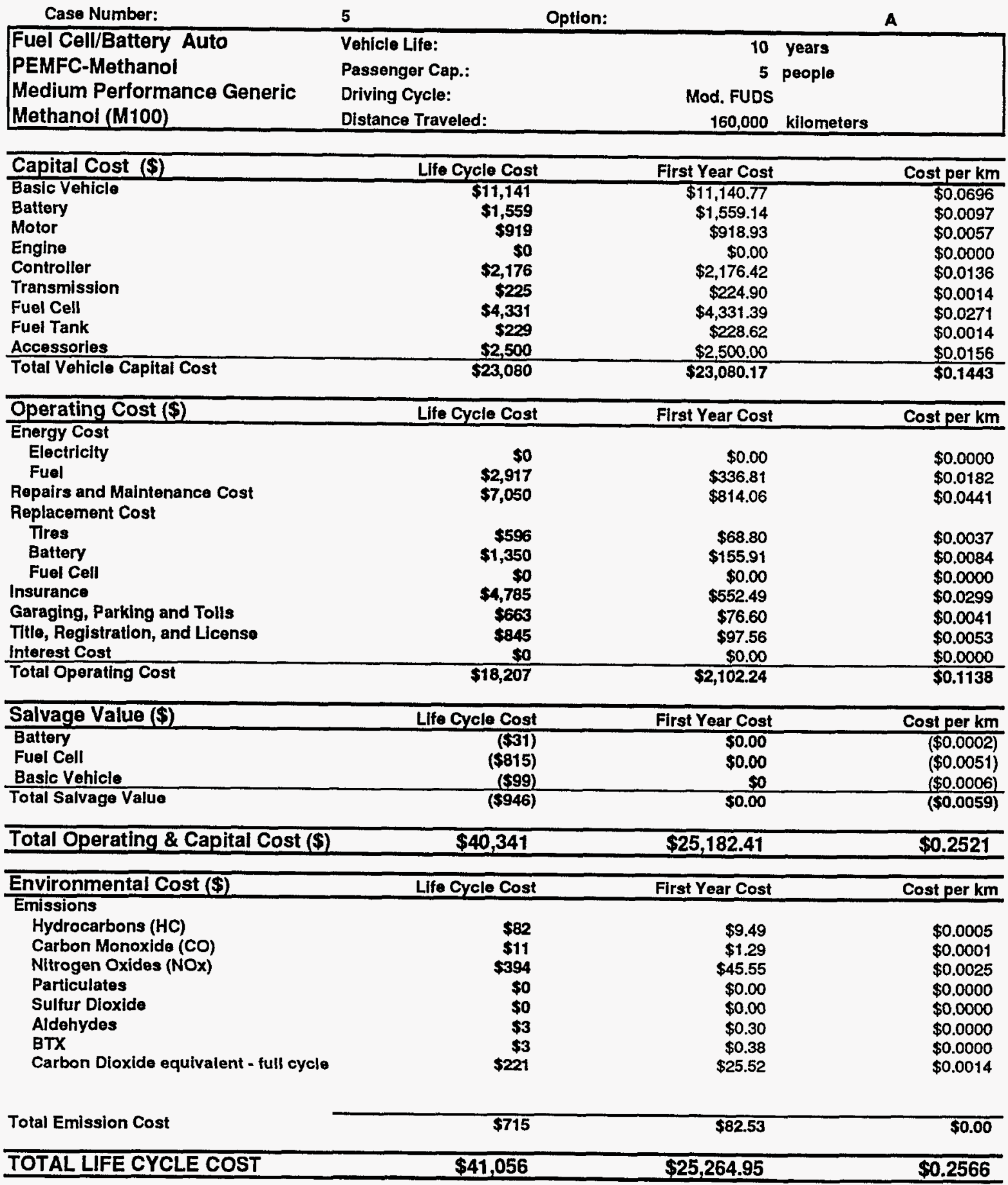


Life Cycle Cost Summary

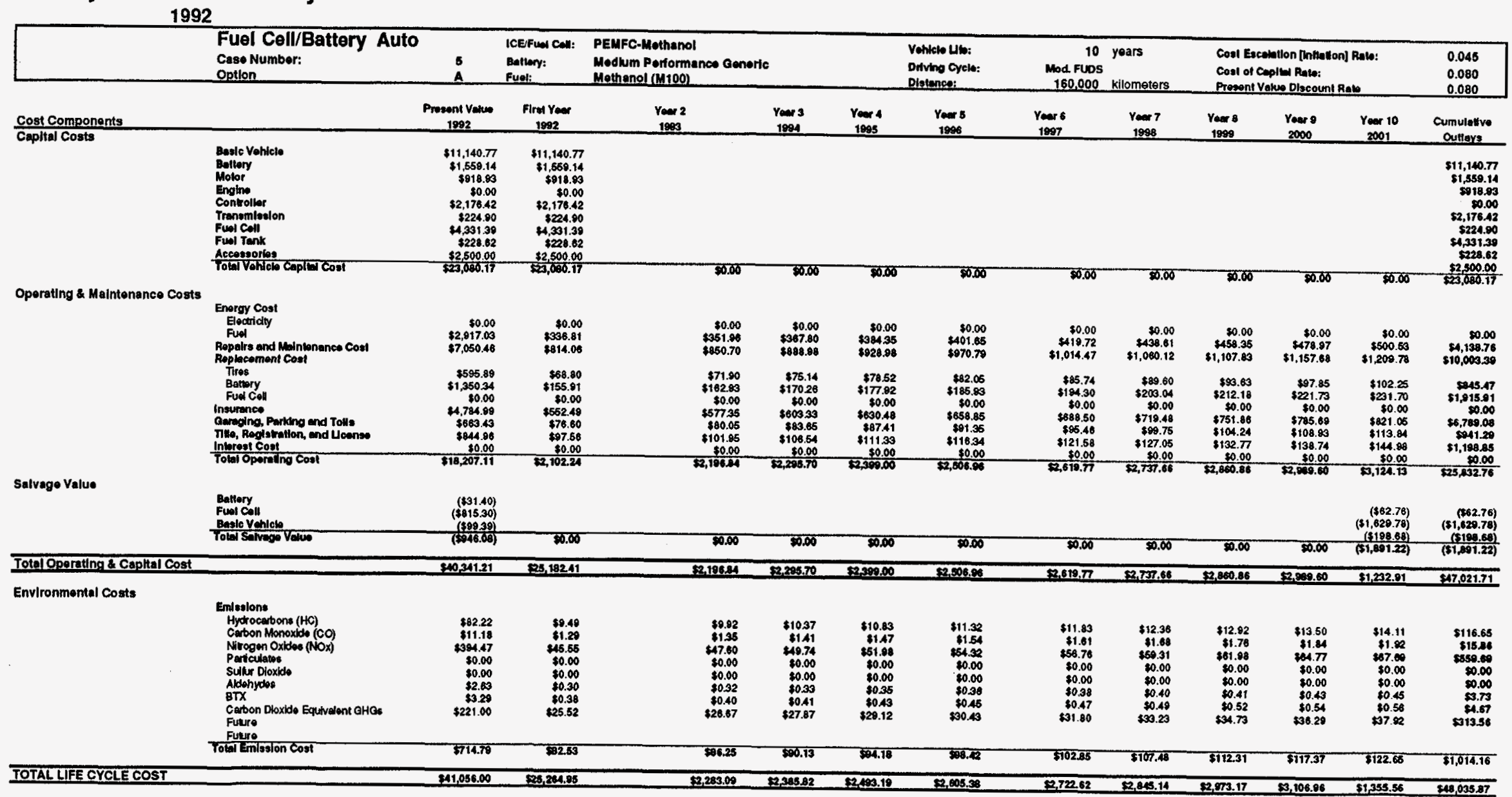




\section{LIFE CYCLE COST MODEL INPUT MODULE}

Case Number:

Basic Vehicle Configuration

\begin{tabular}{l|l|}
\hline Technology Options \\
Type of Vehicle \\
Power System \\
Type of ICE \\
Type of Fuel Coll \\
Type of Fuel & 6 \\
Type of Battery Propulsion & 2 \\
Type of Motor/Controller & 0 \\
Type of Transmission & 3 \\
Status of Technology & \multicolumn{1}{|c|}{ Input } \\
\hline
\end{tabular}

Status of Technology

Vehicle Physical Characteristics

Fuel Colveattery Auto

Passenger Capacity $(2,4,5,6+, 10+)$

Test Woight $(\mathrm{kg})$

Curb Weight (kg)

Base Vehicle Weight (kg)

Accessories $(\mathrm{kg})$

Basic Material Salvage Value $(\$ / \mathrm{kg})$

Life of Vehicle (yr)

Distance Traveled (kst/yr)

Life Cycle Distance Traveled (km)

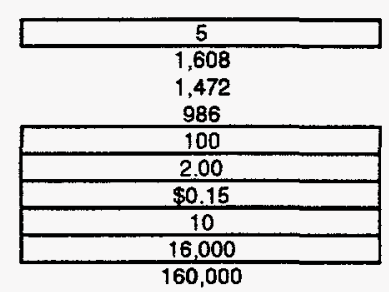

Option:

B

Fuel CelvBattery Auto

Fuel ColvBattery

None

PEMFCHydrogen

Hydrogen

Medium Performance Generic

AC

Automatic

High

Vehicle Performance Characteristics

Accoleration to $88 \mathrm{Km} / \mathrm{h}(\mathrm{s})$

Top Spe日d (km/h)

Gradability (\%)

Rolling Friction Coefficient $(\mathbf{k m} / \mathbf{k m})$

Aerodynamic Drag Coefficient

Peak Power: (kW)

Driving Schodule

Battery Power-10-Energy Ratio

Range (km)

Full Cycles per yea

Partial Cycles per year

\section{Options}

1-8

$1-3$

$0-2$

$0-2$

$0-8$

$0, A-C: 1-10$

$0-3$

1-2

Low/High
Vehicle Frontal Area (sq. m)

Propulsion System Characteristics

Power System

TE:

Engine Power (kW)

Specific Power $(\mathrm{kW} / \mathrm{kg})$

Specific Cost (\$\$ $/ \mathrm{kW})$

Engine Weight (kg)

Fuel Efficiency: (km/) gasoline equiv

(mpg)

Fuel Cell:

Power Rating (kW)

Specific Power [Continuous] (kW/kg)

Power Density [Continuous] (kW/I)

Efficiency

Specific Cost (\$/kW)

Weight $(\mathrm{kg})$

Fuel Efficiency: (km/)

(mpg)

Battery:

Power Rating (kW)

Energy Capacity (kWh)

Specific Energy (Wh/kg)

Specific Power (W/kg)

Efficiency (\%)

Cycle Life

Specitic Cost (\$/kW)

Woight $(\mathrm{kg})$

$80 \%$ Full Range Discharge $(\mathrm{km})$

Number of Replacements

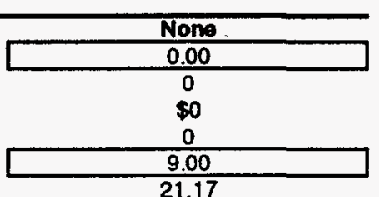

\section{Energy Source}

Fydrogen

Fuel Cost (\$/)

Fuel Efficiency (Vkm)

Electricity Cost (\$/kWhr)

Fuel Efficiency (kWhr/km)

Dive Train

Motor

Peak Power (kW)

Specific Power (kW/kg)

Woight $(\mathrm{kg})$

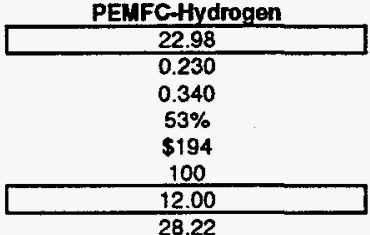

Controller

Peak Power (kW)

Specific Power (kW/kg)

Weight $(\mathrm{kg})$

Transmission System

Peak Power (kW)

Specitic Power (kW/kg)

Woight (kg)

Drive Train Etficiency (\%)

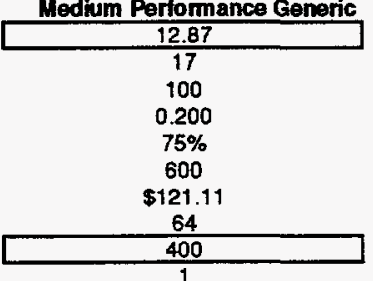

Fuel Tank

Material

Specific Weight ( $\mathrm{gm} / \mathrm{cc}$ )

Specific Cost $(\$ / \mathrm{kg})$

Tank Capacity: (I)

\begin{tabular}{|c|}
\hline 20 \\
110 \\
7 \\
0.010 \\
0.320 \\
\hline 35.85 \\
\hline Mod. FUDS \\
0.75 \\
400 \\
40 \\
355
\end{tabular}

$\$ 0.59$

0.08

$\$ 0.05$

35.85

0.49
73

Tank Woight (w/ Fuel) (kg)

35.85

2.5

14

Automatic

35.85

0.86

42

Economic Analysis Factors

Analysis base year

Present Value Discount Rate (\%100)

Cost Escalation[Inflation] Rate (\%/100)

\begin{tabular}{|c|}
\hline 1992 \\
\hline 0.080 \\
\hline 0.045 \\
\hline
\end{tabular}

Cost of Capital $(\% / 100)$

Loan Term (yr)

Down payment $(\%)$

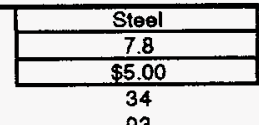

93

\begin{tabular}{|c|}
\hline 0.08 \\
\hline 0 \\
\hline $100 \%$ \\
\hline
\end{tabular}

End of Input Soction 


\section{Life Cycle Cost Summary}

\section{2}

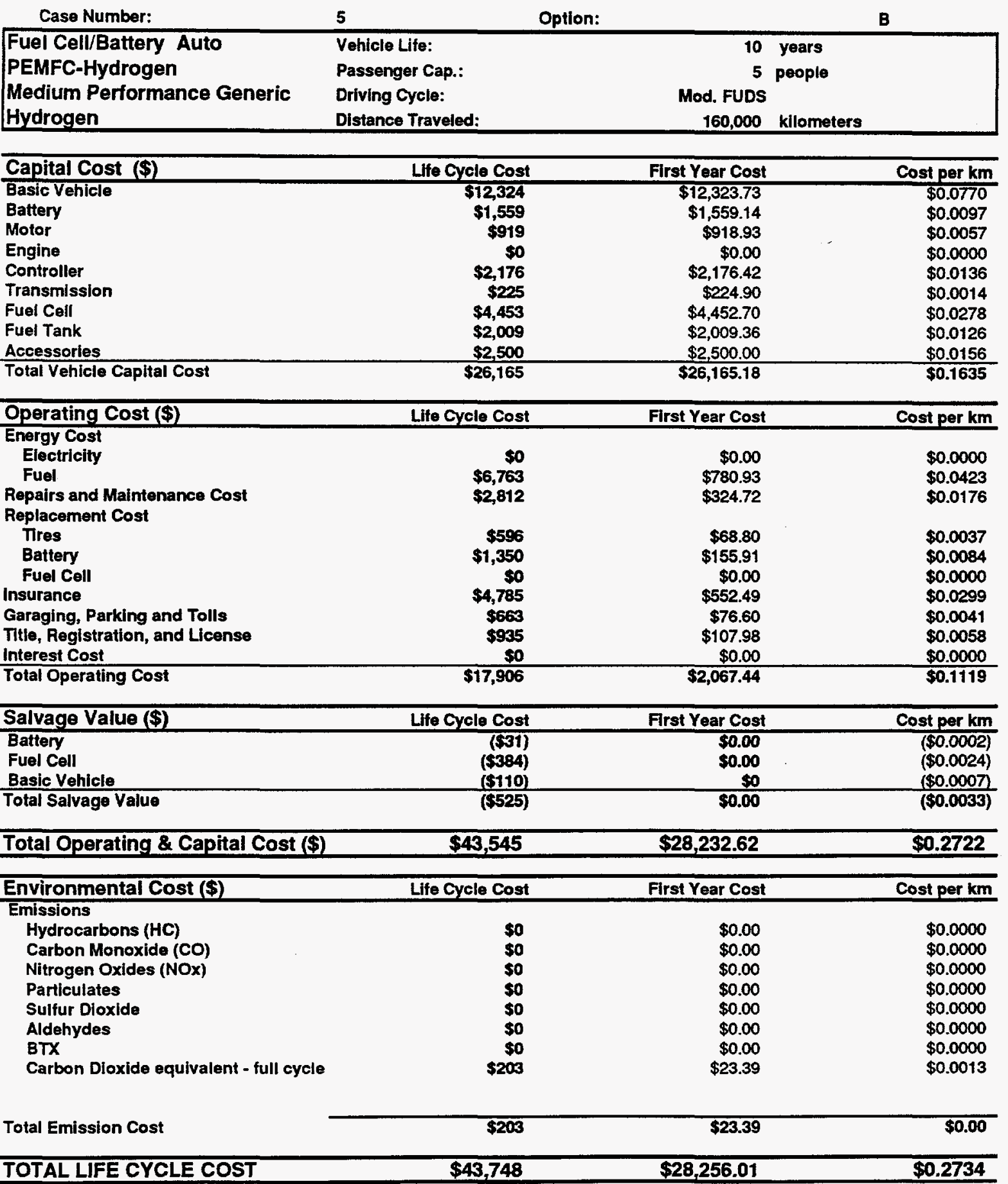




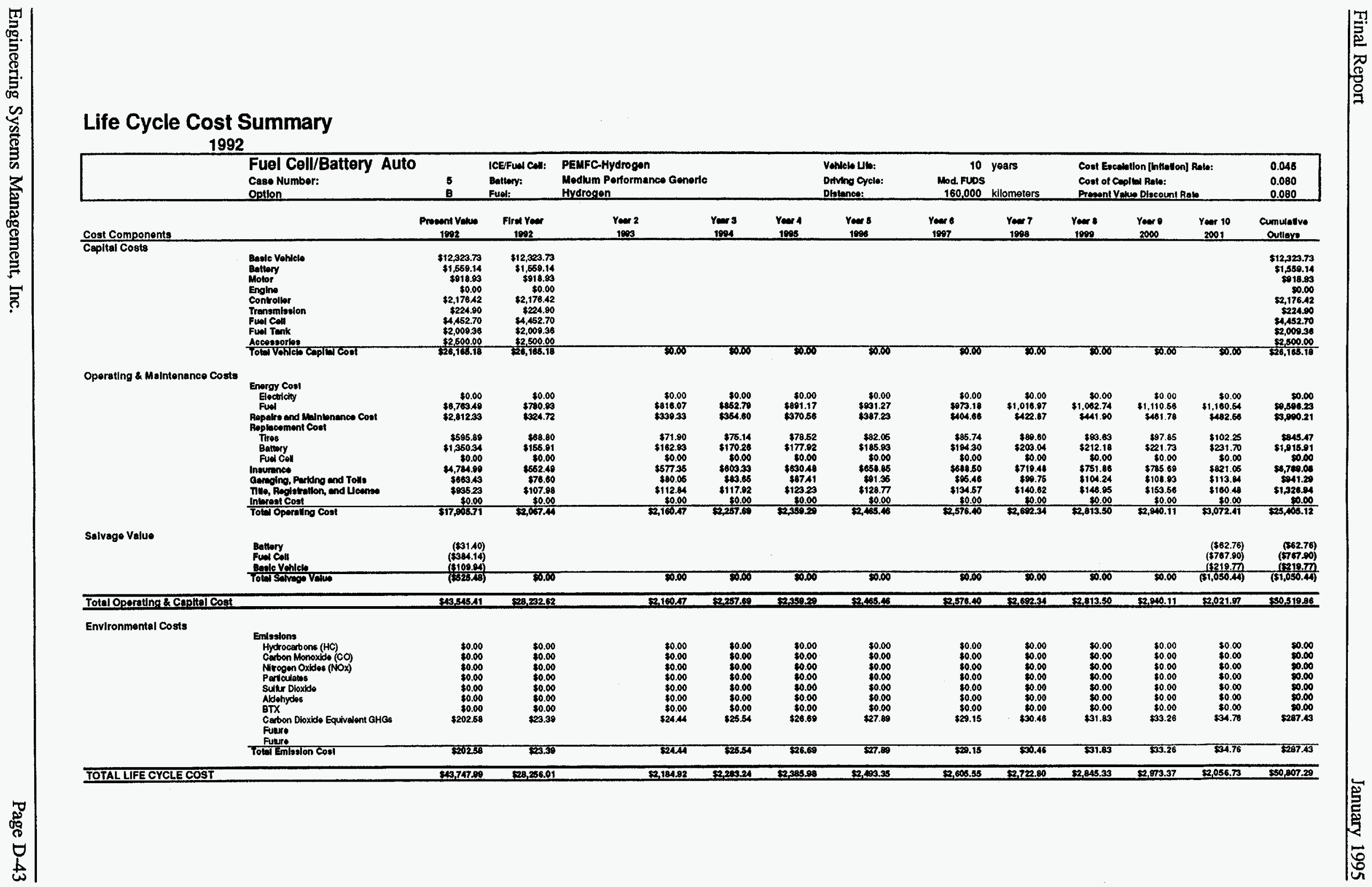




\section{APPENDIX E - ACRONYMS AND ABBREVIATIONS}

\begin{tabular}{|c|c|}
\hline ANL & Argonne National Laboratory \\
\hline BPEV & Battery Powered Electric Vehicle \\
\hline Btu & British Thermal Unit \\
\hline BTX & Benzene, Toluene, Xylene \\
\hline $\mathrm{C}$ & Carbon \\
\hline $\mathrm{CFCs}$ & Chlorfluorocarbons \\
\hline $\mathrm{CH}_{4}$ & Methane \\
\hline $\mathrm{CO}_{2}$ & Carbon Dioxide \\
\hline $\mathrm{CO}$ & Carbon Monoxide \\
\hline DOE & U.S. Department of Energy \\
\hline$\$ / \mathrm{Km}$ & Dollars Per Kilometer \\
\hline E100 & Ethanol $(100 \%)$ \\
\hline EDS & Embedded Data Sets \\
\hline EVs & Electric Vehicles \\
\hline FCEV & Fuel Cell/Battery Powered Electric Vehicle \\
\hline GHG & Greenhouse Gases \\
\hline GRI & Gas Research Institute \\
\hline $\mathrm{HC}$ & Hydrocarbons \\
\hline $\mathrm{H}_{2}$ & Hydrogen \\
\hline ICE & Internal Combustion Engine \\
\hline JPL & Jet Propulsion Laboratory \\
\hline $\mathrm{kg}$ & Kilogram \\
\hline $\mathrm{km}$ & Kilometer \\
\hline LCC & Life Cycle Cost \\
\hline M85 & Blend of $85 \%$ Methanol and $15 \%$ Gasoline \\
\hline M100 & Methanol (100\%) \\
\hline$M \& R$ & Maintenance and Repair \\
\hline $\mathrm{N}_{2} \mathrm{O}$ & Nitrous Oxide \\
\hline $\mathrm{NO}_{\mathrm{x}}$ & Nitrogen Oxides \\
\hline NMOC & Non Methane Organic Compounds \\
\hline PAFC & Phosphoric Acid Fuel Cell \\
\hline PEM & Proton Exchange Membrane \\
\hline PEMFC & Proton Exchange Membrane Fuel Cell \\
\hline PM & Particulate Matter \\
\hline $\mathrm{PM}_{10}$ & Particulate Matter (particles smaller than 10 microns) \\
\hline RFG & Reformulated Gasoline \\
\hline $\mathrm{SO}_{2}$ & Sulfur Dioxide \\
\hline $\mathrm{SO}_{\mathrm{x}}$ & Sulfur Oxides \\
\hline VOC & Volatile Organic Compounds \\
\hline
\end{tabular}

